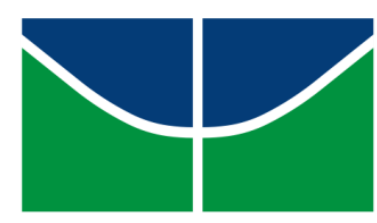

Universidade de Brasília - UnB

Faculdade de Educação - FE

Programa de Pós-Graduação em Educação

Mestrado Acadêmico em Educação

APROPRIAÇÃO DIDÁTICA DO TABLET EDUCACIONAL

POR DOCENTES DO ENSINO MÉDIO DA SECRETARIA DE ESTADO DE

EDUCAÇÃO DO DISTRITO FEDERAL

José Wrigell Menezes Rodrigues

Brasília/ DF

2016 
José Wrigell Menezes Rodrigues

\section{APROPRIAÇÃO DIDÁTICA DO TABLET EDUCACIONAL POR DOCENTES DO ENSINO MÉDIO DA SECRETARIA DE ESTADO DE EDUCAÇÃO DO DISTRITO FEDERAL}

Dissertação de mestrado acadêmico apresentada ao Programa de Pós-Graduação em Educação, na área de concentração Educação e Tecnologia, e eixo de interesse Educação, Tecnologia e Comunicação Pedagógica, da Universidade de Brasília (UnB), como requisito parcial à obtenção do título de Mestre em Educação.

Orientador: Prof. Dr. Gilberto Lacerda dos Santos.

Brasília/ DF 2016 
Ficha catalográfica elaborada automaticamente, com os dados fornecidos pelo(a) autor(a)

Menezes Rodrigues; orientador Gilberto Lacerda dos Santos. -- Brasília, 2016.

$106 \mathrm{p}$.

Dissertação (Mestrado - Mestrado em Educação) -Universidade de Brasília, 2016.

1. Tablet Educacional. 2. TDICE. 3. Apropriação Didática. 4. Inclusão Digital Docente. I. Lacerda dos Santos, Gilberto, orient. II. Título. 


\title{
APROPRIAÇÃO DIDÁTICA DO TABLET EDUCACIONAL POR DOCENTES DO ENSINO MÉDIO DA SECRETARIA DE ESTADO DE EDUCAÇÃO DO DISTRITO FEDERAL
}

\author{
José Wrigell Menezes Rodrigues
}

Dissertação apresentada à Comissão Examinadora do Curso de Pós-Graduação da Faculdade de Educação da Universidade de Brasília como requisito parcial para a obtenção do título de Mestre em Educação, defendida em 19 de maio de 2016. Banca Examinadora constituída pelos professores:

Prof. Dr. Gilberto Lacerda dos Santos (FE/ MTC/ UnB, presidente)

Prof. Dr. Carlos Alberto Lopes de Sousa

(FE/ TEF/ UnB, membro titular interno)

Prof. Dr. Jorge Cássio Costa Nóbriga

(MAT/ UFSC, membro titular externo)

Profa. Dra. Raquel de Almeida Moraes

(FE/ PAD/ UnB, suplente) 


\section{DEDICATÓRIA}

A Deus, que sempre me abençoou.

À minha família, pelo suporte incondicional e extrema compreensão.

Aos meus amigos, pelo carinho de sempre.

Aos professores e colegas do PPGE, por tantas lições. 


\section{AGRADECIMENTOS}

Agradeço a todos que, de uma forma ou de outra, incentivando ou empurrando, me ajudaram a chegar até aqui. Fácil, nunca foi. E é melhor que nunca seja, pois assim aprendemos a dar mais valor às conquistas.

E sendo mais direto...

Agradeço a Deus pelas bênçãos e por ter colocado em minha vida pessoas tão especiais.

À minha família, esposa, filhas, pai e mãe, pela compreensão, pela paciência e por acreditarem em mim.

Aos meus amigos, pelo incentivo e pelo carinho, essenciais nos momentos difíceis.

Aos professores do PPGE, em especial às professoras e aos professores Lúcio Teles, Carlos Lopes, Wivian Weller, Antônio Villar, Catia Piccolo, Ângela Dias e Raquel de Almeida Moraes, pela dedicação e competência com que exercem a profissão.

Ao professor Gilberto Lacerda dos Santos, pela oportunidade de aprender e pela orientação deste trabalho.

Aos colegas do Laboratório Ábaco, pela troca de experiências.

Aos profissionais da Faculdade de Educação, em especial, àqueles que trabalham diretamente no PPGE, pelo excelente trabalho de todo dia.

À Secretaria de Estado de Educação do Distrito Federal, pela licença para estudos e pelo suporte a esta pesquisa. 
Talvez não tenhamos conseguido fazer o melhor, mas lutamos para que o melhor fosse feito.

Não somos o que deveríamos ser, não somos o que iremos ser... Mas, graças a Deus, não somos o que éramos.

Martin Luther King (ativista político estadunidense) 


\section{RESUMO}

A escola está inserida em uma sociedade cada vez mais conectada pela internet, então é inevitável que seus dispositivos estejam presentes no cotidiano escolar. Um desses dispositivos é o tablet. Numa ação do Prolnfo, tablets educacionais foram distribuídos no DF para promover a inclusão digital dos professores da Rede Pública. Assim, este trabalho analisa como os docentes do Ensino Médio se apropriaram dessa ferramenta, incluindo-o em sua rotina pedagógica. O referencial teórico é composto pelos estudos e pesquisas de Kensky (2005, 2012); Lévy (1993, 2000a, 2000b); Lacerda Santos (2010, 2012, 2014); Gianolla (2006); Perrenoud (2000); Lemos (2010); Rogoff (1995); Rüdiger (2007, 2013); Stake (2012); Weiser (1991); Bardin (2011), entre outros. Trata-se de estudos de caso realizados com colaboradores que aceitaram ou recusaram o tablet educacional. Foram utilizadas como estratégias de investigação o questionário on-line e a entrevista semiestruturada. A análise das informações coletadas na pesquisa indica que o(a) docente não se apropriou didaticamente do tablet educacional, pois vários fatores dificultaram tal ação, como formação insuficiente, qualidade baixa do hardware, pouco ou nenhum suporte para uso na escola, falta de diretriz pedagógica e até mesmo a guarda (porte e posse) do dispositivo.

Palavras-chave: Tablet Educacional. TDICE. Apropriação Didática. Inclusão Digital Docente. 


\section{ABSTRACT}

The school is set in a society increasingly connected through the Internet, so it is inevitable that your devices are in everyday school life. One such device is the educational tablet, an action of Prolnfo, which aims to promote digital inclusion teacher. This work looks at how the teachers of high school appropriated this tool, including it in their teaching routine. The theoretical framework consists of the studies and research Kensky (2005, 2012), Levy (1993, 2000a, 2000b), Lacerda Santos (2010, 2012, 2014), Gianolla (2006), Perrenoud (2000), Lemos (2010), Rogoff (1995), Rüdiger (2007, 2013), Stake (2012), Weiser (1991), Bardin (2011), among others. This is case study of employees who accepted or recursaram educational tablet. They were used as research strategies questionnaire and semi-structured interview. The analysis of the information collected in the survey indicates that (a) teacher did not appropriate didactically educational tablet because many factors hindered such action, such as training for insufficient use, low hardware quality, little or no support for use in school, lack pedagogical guidance and even the guard (size and ownership) of the device.

Keywords: Educational Tablet. TDICE. Didactic Appropriation. Teacher Digital Inclusion. 


\section{LISTA DE FIGURAS}

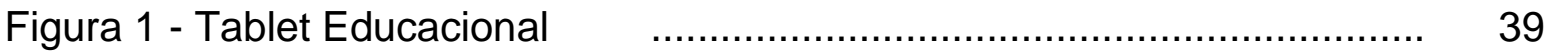

Figura 2 - Estrutura da pesquisa $\quad$.......................................................... 45

Figura 3 - Apropriação didática $\quad$ …………………………………..... 82 


\section{LISTA DE TABELAS}

Tabela 1 - CRE e colaboradores de pesquisa $\quad$........................................ 55

Tabela 2 - Licenciatura (formação inicial para exercício do magistério) .... 56

Tabela 3 - Motivos para aceitação ou recusa do tablet educacional $\quad$......... 58

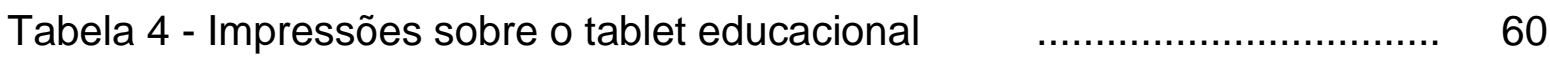

Tabela 5 - Apresentação dos colaboradores de pesquisa para entrevista $\quad$.... 64 


\section{LISTA DE SIGLAS}

CE - Colaborador de Pesquisa Etapa Entrevista Semiestruturada CEM - Centro de Ensino Médio

CEMTN - Centro de Ensino Médio de Taguatinga Norte

CGI - Comitê Gestor da Internet

$\mathrm{CQ}$ - Colaborador de Pesquisa Etapa Questionário

CRE - Coordenação Regional de Ensino

DF - Distrito Federal

DVD - Digital Versatile Disc (disco óptico digital)

EAPE - Escola de Aperfeiçoamento dos Profissionais da Educação

UE - Unidade de Ensino

FE - Faculdade de Educação

FNDE - Fundo Nacional de Desenvolvimento da Educação

GDF - Governo do Distrito Federal

LEM - Língua Estrangeira Moderna

MEC - Ministério da Educação

NTE - Núcleos de Tecnologia Educacional

PAR - Plano de Ações Articuladas

PC - Personal Computer

PPP - Projeto Político-Pedagógico

PROINFO - Programa Nacional de Tecnologia Educacional

PROUCA - Programa Um Computador por Aluno

SEEDF - Secretaria de Estado de Educação do Distrito Federal

TCLE - Termo de Consentimento Livre e Esclarecido

TDICE - Tecnologias Digitais de Informação, Comunicação e Expressão

TIC - Tecnologias da Informação e Comunicação

TV - Televisão

UnB - Universidade de Brasília 


\section{SUMÁRIO}

1. INTRODUÇÃO

1.1. Justificativa da Pesquisa $\quad$............................................................. 17

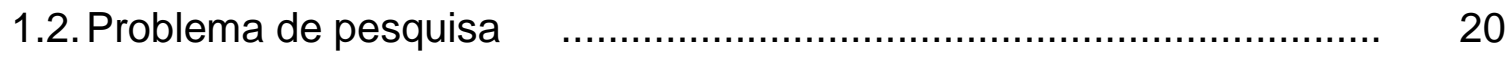

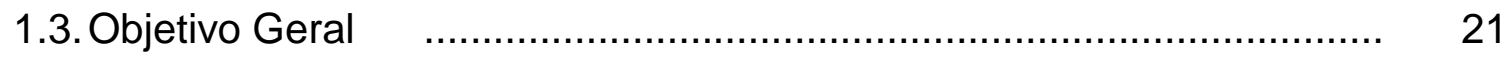

1.4. Objetivos Específicos $\quad$ ………………………........................ 21

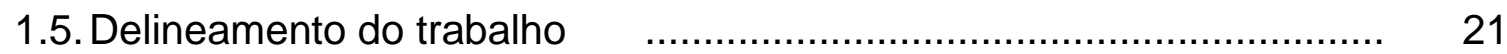

2. SOB OS OMBROS DE GIGANTES (REFERENCIAL TEÓRICO) $\quad \ldots \ldots \ldots . . . .23$

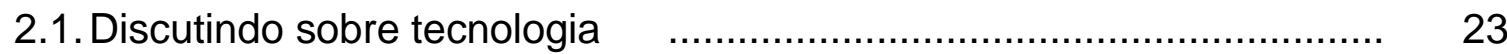

2.2. A questão da apropriação didática $\quad$............................................... 25

2.3. As faces da inovação pedagógica $\quad$ …………………………….... 29

2.4. Formação docente para uso das TDICE $\quad$........................................ 31

3. O CENÁRIO PARA INSERÇÃO DAS TDICE NA ESCOLA $\quad \ldots \ldots \ldots \ldots \ldots . . . . . .35$

3.1. O Programa Nacional de Tecnologia Educacional (Prolnfo) $\quad$........... 35

3.2. O que pensam e o que sabem os(as) docentes sobre as TDICE $\quad \ldots . . .36$

3.3. A estrutura das escolas para o uso do tablet educacional $\quad$.............. 37

3.4. Configuração do tablet educacional ……………................................. 38

3.5. O curso de formação para uso da ferramenta didática $\quad$...................... 39

4. O OLHAR E O MÉTODO …................................................................ 41

4.1. A pesquisa qualitativa $\quad$..................................................... 41

4.2. O estudo de caso para Robert Stake $\quad$........................................... 42

4.3. Colaboradores de pesquisa $\quad$........................................................ 44

4.4. A estrutura da pesquisa: níveis de aprofundamento $\quad$......................... 44

4.5. Estratégias de investigação $\quad$......................................................... 46

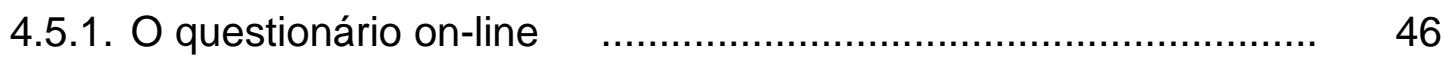

4.5.2. A entrevista semiestruturada …………................................. 51

5. INFORMAÇÕES OBTIDAS PELO QUESTIONÁRIO ON-LINE E PELAS ENTREVISTAS SEMIESTRUTURADAS ……....... 54

5.1. Campo de pesquisa: chegando e conhecendo o terreno $\quad$.................... 54

5.2. Informações oferecidas pelo questionário on-line e considerações iniciais $\quad$..... $\quad 55$

5.3. Os colaboradores de pesquisa na etapa das entrevistas semiestruturais $\quad$..... 64

5.4. Informações oferecidas pelas entrevistas semiestruturadas
considerações iniciais

6. APROPRIAÇÃO DIDÁTICA DO TABLET EDUCACIONAL $\quad$............... 79

7. CONSIDERAÇÕES FINAIS …........................................................ 85 
8. REFERÊNCIAS BIBLIOGRÁFICAS …….......................................... 89

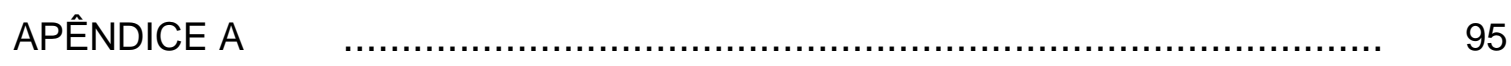

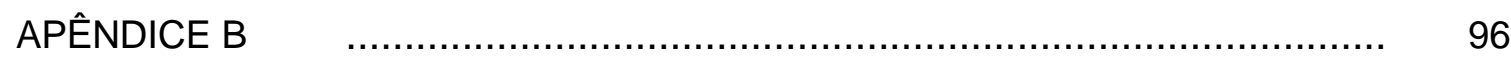

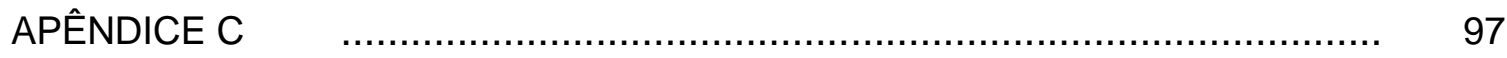

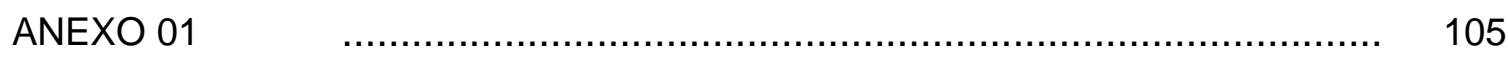

ANEXO 02 


\section{INTRODUÇÃO}

Segundo o Comitê Gestor da Internet no Brasil (CGI), na pesquisa TICKids Online Brasil 2014 1 , 81\% dos jovens entre 9 e 17 anos acessam a internet todos os dias ou quase todos, $79 \%$ têm perfis em redes sociais e $68 \%$ utilizam a internet para trabalhos escolares. Estes dados nos levam a crer que as Tecnologias Digitais de Informação, Comunicação e Expressão (TDICE) ${ }^{2}$ já estão presentes no cotidiano de crianças e adolescentes.

Segundo Lacerda Santos (2010, p. 16-17), o acesso às TDICE desenvolve novas formas e estruturas de pensamento. Dessa forma, a escola desempenha a função de consolidação do sujeito, considerando a necessidade da construção de saberes significativos com base nesse sujeito e sua nova visão de mundo.

Ainda segundo Lacerda Santos (2010, p. 17), paralelo à apropriação das TDICE há um movimento de ressignificação das disciplinas escolares e reestruturação do tratamento didático.

Assim, temos o(a) estudante habituado(a), e até mesmo desejando, a mudança na didática em sala de aula através das TDICE, e a presença da ferramenta (tablet) na escola. Então o que falta no sistema para que a roda gire, para que ocorra a tão esperada mudança?

$\mathrm{Na}$ mesma direção, porém bem mais lenta, está a apropriação das TDICE pelo(a) professor(a). Outra pesquisa do CGI, a TIC Educação $2012^{3}$, revela que apenas $2 \%$ dos docentes utilizam a tecnologia como suporte às suas aulas em sala, apesar de 92\% terem acesso à Internet em suas residências. É importante ressaltar que a pesquisa TIC Educação 2014 revelou que 96\% dos professores utilizam recursos obtidos na internet para a preparação de aulas ou atividades com estudantes, sendo que $92 \%$ deles fazem isso por motivação própria.

\footnotetext{
${ }^{1}$ Fonte: < http://www.cgi.br/media/docs/publicacoes/2/TIC_Kids_2014_livro_eletronico.pdf >. Acesso em: 19 fev. 2016, às 20h12min.

${ }^{2}$ Expressão criada pelo Prof. Dr. Gilberto Lacerda dos Santos (FE UnB/DF) em 2014. Em seu entendimento, são assim definidas por promoverem a convergência de todas as mídias e por serem suportes privilegiados e inovadores para que nos informemos com mais intensidade, nos comuniquemos com mais agilidade e nos expressemos com mais liberdade. Vide <http://www.revistas.ufg.br/index.php/interacao/article/view/28790/17722>.

${ }^{3}$ Fonte: <http://www.cetic.br/educacao/2012/>. Acesso em: 09 set. 2013, às 21h10min.
} 
Para tentar amenizar ou superar tamanha discrepância, o Governo Federal lançou o Programa Educação Digital ${ }^{4}$, que visa fornecer computadores interativos ${ }^{5}$ para a escola (equipamento desenvolvido pelo MEC, que reúne projeção, computador, microfone, DVD, lousa e acesso à internet) e o tablet para os docentes. Os estados aderem à proposta, dividem os custos e são beneficiados com a formação nacional através da Escola de Gestores ${ }^{6}$.

O Governo do Distrito Federal (GDF) aderiu ao programa e desde 2011 tem recebido as ferramentas anunciadas no programa. Em 2011, as escolas que participavam do Programa Mais Educação receberam os computadores interativos e em 2013 os docentes do Ensino Médio receberam os tablets.

Durante a entrega dos tablets do Programa Nacional de Tecnologia Educacional (Prolnfo), no dia 23 de maio de 2013, para aproximadamente 3.000 professores(as) do Ensino Médio que estavam no auditório do Centro de Convenções Ulisses Guimarães (Brasília/ DF), o então governador do Distrito Federal, Agnelo Queiroz, afirmou que "essa ferramenta [o tablet] vai ajudar os professores na didática e tornar a escola mais prazerosa"7.

Logo após a cerimônia de entrega dos tablets, os docentes participaram da aula inaugural da capacitação para uso pedagógico do dispositivo. Questionado sobre a preparação que os(as) professores(as) receberiam, o ocupante do cargo de secretário de educação do DF na época, Denilson Bento da Costa, disse: "Estamos preparando uma formação para que eles se apropriem de todas as tecnologias disponíveis no tablet e para que possam realmente utilizá-lo como uma ferramenta pedagógica em sala de aula".

Sem anunciar como o(a) docente iria utilizar tal ferramenta em sua rotina pedagógica, o governador e o secretário de educação afirmaram que a mudança iria

\footnotetext{
${ }^{4}$ Fonte: <http://portal.mec.gov.br/index.php?option=com_content\&id=17479>. Acesso em: 10 out. 2013, às 20h02min.

${ }^{5}$ Segundo o Ministério da Educação, computador interativo é um equipamento que reúne projeção, computador, microfone, DVD, lousa e acesso à internet, conforme consta em: $<$ http://portal.mec.gov.br/index.php?option=com_content\&view=article\&id=17479:ministerio-distribuiratablets-a-professores-do-ensino-medio\&catid=215>. Acesso em: 10 jul. 2015, às $22 \mathrm{~h} 11 \mathrm{~min}$.

$<$ http://portal.mec.gov.br/index.php?option=com_content\&view=article\&id=12337\&ltemid=693>. Acesso em: 10 out. 2013, às 21h03min.

${ }^{7}$ Fonte: <http://www.se.df.gov.br/?p=12081>. Acesso em: 08 set. 2013, às 9h45min.
} 
acontecer em sala de aula, ou seja, que as formas de ensinar e aprender iriam ser afetadas pela incorporação do tablet à rotina pedagógica.

Alguns meses depois, mesmo com a capacitação sendo realizada, pouco tem sido percebido em sala de aula, como relatou ao Canal Último Segundo ${ }^{8}$ a professora Ana Lúcia Bontempo, regente no Centro de Ensino Médio de Taguatinga Norte (CEMTN):

"Na sala, o tablet não funciona. A internet é lenta, ele é lento, não conseguimos baixar os aplicativos. O que ganhei está guardado, porque já tenho notebook. Não conheço ninguém que está usando em sala".

Desta forma, uma investigação tornou-se necessária para conhecermos como a implantação desse programa tem ocorrido nas escolas públicas e como os(as) professores(as) têm enfrentado os obstáculos encontrados pelo caminho. Não apenas para justificar o investimento financeiro, mas também para que possamos (re)formular maneiras de garantir o salto qualitativo almejado para a educação do DF.

\section{1}

JUSTIFICATIVA

Esta investigação vislumbrou perceber a apropriação didática das TDICE pelos(as) docentes do Ensino Médio. Para isso verificamos e analisamos como a rotina didática e a gestão pedagógica ${ }^{9}$ foram afetadas pela ferramenta pedagógica (tablet educacional). Assim, partimos da literatura existente sobre tecnologia e informática na educação e formação docente, para construirmos um caminho e uma forma de caminhar que expôs como tem sido o processo de apropriação do tablet educacional por professores(as) em sua rotina diária, ou seja, na relação com o conhecimento e com a didática em sala de aula.

Alguns estudiosos, entre eles Lacerda Santos e Braga (2012); Lacerda Santos (2010; 2012); Imbernón (2009); Lévy (1993; 2000a, 2000b); Alava (2002);

\footnotetext{
${ }^{8}$ Fonte: <http://ultimosegundo.ig.com.br/educacao/2013-08-22/professor-e-chave-para-o-sucesso-nouso-de-tecnologia-na-sala-de-aula.html>. Acesso em: 08 set. 2013, às11h55min.

${ }^{9}$ A gestão pedagógica trata da organização, coordenação, liderança e avaliação dos processos e ações diretamente voltados para a promoção da aprendizagem dos estudantes e formação dos(as) docentes (LÜCK, 2009).
} 
Afonso (1993); Demo (2006); Gianolla (2006) e Perrenoud (2000) analisaram o surgimento e a interferência das TDICE nas escolas e na rotina pedagógica dos docentes, bem como a formação permanente que se faz necessária para o bom exercício do magistério e a adaptação aos novos tempos e suas linguagens.

Este trabalho tem foco em algo recém-chegado nas escolas públicas do DF, o tablet educacional. Visto como mais uma promessa de mudança pedagógica, essa ferramenta pode se transformar em apenas mais um artigo de luxo abandonado nas gavetas e armários ou pode significar o surgimento de um portal para uma nova relação com o conhecimento e uma nova forma de relacionamento entre os sujeitos escolares. Desta forma, nos dispusemos a verificar o caminho escolhido pelo(a) docente nesse processo e identificamos obstáculos, facilidades, avanços, resistências e êxitos no trabalho pedagógico mediado pelo tablet educacional.

A literatura pertinente (artigos, dissertações e teses) registra depoimentos variados sobre o uso de outras ferramentas tecnológicas promissoras que foram colocadas à disposição de escolas e de docentes, como por exemplo, computadores e notebooks. Medo, ignorância, má formação... são muitos os motivos que justificam o não uso, o mau uso ou o desuso ${ }^{10}$ dessas ferramentas.

Neste momento, passaremos a detalhar alguns documentos dessa literatura, a fim de evidenciarmos a promessa da contribuição deste trabalho para 0 conhecimento do objeto em estudo. Pois, analisar o uso do tablet na escola pelo(a) docente, à luz das pesquisas existentes, mesmo que a ferramenta tenha sido similar, poderá fornecer novas perspectivas de aceitação, apropriação e real mudança na organização do trabalho pedagógico.

Fahl et al. (2013) realizaram um estudo sobre os tablets no Ensino Médio que apontou, entre outros, que as escolas falham em oferecer internet para conexão dos dispositivos; que os (as) docentes têm pouco ou nenhum conhecimento sobre a ferramenta pedagógica; e que faltam habilidades didáticas para uso do tablet, o que gerou uma integração superficial da prática de ensino com o recurso tecnológico.

Já Giacomazzo e Fiuza (2014) destacam que é preciso incorporar, no ambiente escolar, outras linguagens, recursos e metodologias que promovam o trabalho colaborativo entre os(as) docentes. Ressaltam também que os(as) professores(as) buscam uma sobreposição do conhecimento de uso do computador

\footnotetext{
${ }^{10}$ Conforme NASCENTES (1998, p. 203) o desuso será caracterizado como a interrupção do uso.
} 
em outras plataformas (Windows, por exemplo) para operar o tablet e que eles(as) consideram importante o uso de novas tecnologias na educação, apesar de não conseguirem explicar o motivo pelo qual receberam o tablet educacional. E, por último, revelam que os(as) docentes não estão preparados para o uso da ferramenta, devido à falta de formação pedagógica específica, condições precárias de infraestrutura técnica e, ainda, sobrecarga de atividades.

Outro estudo, realizado por Cruz e Matos (2014), novamente indica a fragilidade na formação docente, tanto na inicial quanto na continuada. Esses estudiosos acrescentam que há pouco material voltado exclusivamente para o ensino, o que poderia dificultar o uso do tablet na escola.

Lins et al. (2013), ao estudarem as dificuldades e resistências de docentes ao usarem novas tecnologias, perceberam que a formação desses professores, em qualquer área da informática, estava defasada, pois ocorreu há mais de cinco anos (74,99\%). Isto indica também uma defasagem das linguagens utilizadas no trabalho docente e o equipamento. Essa mesma pesquisa confirma que $89,28 \%$ dos(as) docentes têm internet, que 100\% possuem computador em suas residências, e ainda evidencia que existe pouca sensibilidade da maioria dos(as) professores(as) em buscar aperfeiçoamento profissional para o uso das tecnologias digitais.

Quaresma et al. (2014), ao acompanharem a implantação do tablet educacional na rede estadual de ensino do Rio Grande do Sul, perceberam que a fluência tecnológica do(a) professor(a) e o conhecimento prévio da ferramenta e de seu sistema são fundamentais para a apropriação da pedagógica da tecnologia. Ressaltam que os momentos de formação são cruciais para o crescimento coletivo, principalmente os realizados na própria escola.

Estes estudos apontam para a falta de formação específica para uso da TDICE, infraestrutura carente, conexão ruim, falta de habilidades e até mesmo interesse por parte dos(as) docentes. Mas esta dissertação buscou ir além das dificuldades supracitadas na implantação de tecnologias digitais na escola. Nossa pesquisa focou no uso, na prática de docentes que, apesar dos obstáculos, estão utilizando o tablet educacional em sua rotina pedagógica, ou seja, na superação das dificuldades e na inovação didática. Diante disso, acreditamos estar contribuindo para o entendimento das questões referentes ao trabalho pedagógico mediado pelas tecnologias digitais. 


\title{
1.2
}

PROBLEMA DE PESQUISA

O tablet educacional, posto como ferramenta pedagógica aos docentes do Ensino Médio da Rede Pública de Ensino do DF, oferece uma oportunidade de modificação na comunicação institucional (fluidez de informação), na forma de se realizar a coordenação pedagógica, na interação com as pessoas e com o conhecimento, ou seja, esta ferramenta midiática carrega um propósito de estabelecer uma ponte entre a realidade social vivida fora da escola e a demanda cada vez maior por uma educação conectada. A família, os docentes e os estudantes estão gradativamente sendo imersos em um mundo interligado e conectado pela internet, e a escola, representando um fragmento dessa realidade, já avança para a computação ubíqua ${ }^{11}$ (WEISER, 1991), pois muito de seu funcionamento e organização dependem do computador, de uma máquina para realizar as mais variadas tarefas e maximizar o potencial humano.

Segundo Kenski (2005, p. 1-2):

\begin{abstract}
Assim como cada modalidade de ensino requer o tratamento diferenciado do mesmo conteúdo - de acordo com os alunos, os objetivos a serem alcançados, o espaço e tempo disponíveis para a sua realização - cada um dos suportes mediáticos tem cuidados e formas de tratamento específicas que, ao serem utilizadas, alteram a maneira como se dá e como se faz a educação.
\end{abstract}

Desta forma, paira sobre nossas cabeças, provocando inquietação, a seguinte pergunta: Como tem sido a apropriação didática do tablet educacional pelos(as) docentes do Ensino Médio da Rede Pública do DF? Este trabalho de investigação acaba fazendo aflorar outros questionamentos relacionados a esse fenômeno, por exemplo: Como estes(as) docentes estabelecem suas relações com esta ferramenta didática? Será que eles(as) reconhecem o tablet como ferramenta didática? Eles(as) conhecem as diretrizes e os objetivos da distribuição dos tablets educacionais para os docentes da rede pública? Quais foram os motivos que o(a) fizeram aceitar ou não o tablet? Ou seja, como foi o percurso de apropriação didática deste dispositivo midiático, e que formas específicas foram criadas para o trabalho pedagógico?

${ }^{11}$ Termo utilizado para descrever a onipresença da informática no cotidiano das pessoas. 


\section{3}

OBJETIVO GERAL

- Analisar como tem sido o percurso de apropriação didática do tablet educacional, fornecido pelo GDF, pelos(as) docentes do Ensino Médio da Rede Pública de Ensino.

\section{4}

OBJETIVOS ESPECÍFICOS

- Conhecer os motivos que levaram o(a) docente a não aceitar/aceitar, não ficar/ficar e não usar/usar o tablet educacional em sua rotina pedagógica;

- Verificar se houve mudança na rotina pedagógica dos(as) docentes que usam o tablet educacional;

- Caracterizar o uso e o mau uso pedagógico do tablet educacional, de acordo com a premissa do Programa Nacional de Tecnologia Educacional (Prolnfo).

\section{5}

DELIMITAÇÃO DO TRABALHO

Este trabalho está estruturado em oito capítulos com a finalidade de construir um caminho para uma leitura que permita conhecer, entender, criticar e formular visões sobre o tema, vislumbres de como as TDICE podem mediar a relação entre conhecimento e pessoas, tornando o processo mais fluente e prazeroso.

No primeiro capítulo, montamos um cenário no qual as pessoas utilizam as ferramentas tecnológicas e a internet para ampliarem suas possibilidades, bem como apresentamos os objetivos da pesquisa e a questão a ser investigada.

$\mathrm{Na}$ etapa seguinte, segundo capítulo, revisamos as pesquisas existentes na área, com outras ferramentas pedagógicas ligadas ao mesmo programa, oferecemos um quadro teórico e as discussões acadêmicas sobre o tema.

$\mathrm{Na}$ terceira parte, discutimos o cenário para inserção das TDICE na escola, abordando o Prolnfo e o que os(as) docentes pensam e sabem sobre as tecnologias 
digitais, como essas instituições se prepararam para a chegada dos tablets, qual é a configuração do dispositivo e como se deu a formação para o uso pedagógico dessa ferramenta. O propósito dessa discussão foi fornecer elementos para o entendimento da pesquisa e de seus resultados em uma realidade objetiva, em que diversos fatores influenciam a tomada de decisões sobre a rotina pedagógica.

No quarto capítulo, é feita uma explanação sobre a pesquisa qualitativa, ou seja, evidenciaremos com que olhar nos voltamos para o fenômeno a ser estudado. $E$, em seguida, discutimos sobre o método escolhido para a abordagem investigativa (estudo de casos), as estratégias e instrumentos, bem como a caracterização dos colaboradores da pesquisa.

O quinto capítulo apresenta as informações obtidas pelo questionário on-line e pelas entrevistas semiestruturadas, abordando também a exploração do campo de pesquisa.

A apropriação didática do tablet educacional e os 10 (dez) indicadores são os temas do sexto capítulo desta dissertação.

A caracterização do uso ou mau uso didático do tablet educacional, na perspectiva dos colaboradores de pesquisa, foi realizada no capítulo 7 .

As considerações finais foram feitas no capítulo 8 deste trabalho, apontando outros caminhos para a apropriação didática plena da ferramenta pedagógica e, também, de novos rumos possíveis para essa discussão. 


\section{2}

\section{SOB OS OMBROS DE GIGANTES (REFERENCIAL TEÓRICO)}

A provocação para esta investigação acadêmica surgiu de uma inquietação do pesquisador enquanto docente nas escolas públicas do $\mathrm{DF}^{12}$. Diária e gradativamente, vemos professores e professoras portando aparelhos tecnológicos de informação e comunicação, principalmente dispositivos móveis (smartphones e tablets), consumindo mídias e utilizando a sua linguagem própria. O senso comum pode fornecer várias explicações para o fenômeno, mas o compromisso acadêmico nos compele a ir além de compreensões superficiais. Precisamos conhecer a motivação, as concepções e as relações que são estabelecidas entre as pessoas e os dispositivos e entre as próprias pessoas que os utilizam como forma de aproximação.

A partir da constatação de que a percepção superficial não é suficiente, buscaremos uma visão mais detalhada desse fenômeno e, para tal, vários estudos poderão nos oferecer sustentação para seu entendimento e discussões. Assim, esperamos ter uma compreensão mais aprofundada e coerente sobre o fenômeno.

\section{1}

\section{DISCUTINDO O SENTIDO DE TECNOLOGIA}

Kensky (2012, p. 15) nos traz uma definição crucial na discussão sobre o que pode ser a tecnologia. Para essa pesquisadora, tecnologia é poder. Diariamente, somos surpreendidos pela tecnologia (drones, impressora 3D, nuvens de armazenamento, sistemas de drenagem de águas pluviais, captação de energia solar etc.). Ou seja, demonstrações do que o ser humano pode fazer, de como nós intervimos na natureza, na relação humana, na percepção do tempo e na vida. $E$ não se trata apenas do poder enquanto ação ou autoridade, mas também como domínio sobre a própria consciência e sobre a existência.

Lévy (2000a) demarca dois conceitos muito importantes para ampliarmos a discussão sobre o uso do tablet educacional pelos(as) docentes do Ensino Médio, o

\footnotetext{
${ }^{12}$ O pesquisador é professor efetivo da SEEDF desde 1998.
} 
de tecnologias da inteligência e o de inteligência coletiva. Para ele, o primeiro tem relação com representações utilizadas no cotidiano (linguagens, sistema de signos, recursos lógicos e instrumentos de comunicação). Nesse sentido, o ser humano não conseguiria pensar sozinho e sem o auxílio de tais ferramentas. $O$ segundo, muito útil para a construção social em instituições, diz respeito ao pensamento compartilhado, criado por sujeitos em tempos e espaços diferentes, sustentado por uma rede de conexões que tornam o conhecimento interligado com 0 desenvolvimento do indivíduo, mas que impulsiona o crescimento de todos ligados a essa rede. Esta conexão é estabelecida através das redes de computadores, a internet.

Esses dois conceitos nos levarão a outro, o de Cibercultura (LÉVY, 2000b), que pode ser definida como o conjunto dos conhecimentos disponíveis no ambiente virtual e cibernético. O que se espera com o uso da ferramenta, conforme anunciado no lançamento do programa no DF, é que ela seja utilizada para ampliar as possibilidades de intervenção e interação pedagógicas, criando uma comunidade de conhecimento, que promova o surgimento de uma cultura de ensino e de aprendizagem intermediada pelo tablet educacional. Não apenas a digitalização dos processos (a simples substituição do papel pelo dispositivo digital), mas a criação de novas vias de comunicação e produção do conhecimento, conforme expectativa de ações para a inclusão digital de professores(as).

Desta discussão surgem as Tecnologias Digitais de Informação, Comunicação e Expressão (TDICE), termo cunhado por Lacerda Santos (2014), que sintetiza várias formas de interação mediadas por conexão em rede, produção, consumo e divulgação de pensamentos e posicionamentos sociais.

Assim, a tecnologia amplia as possibilidades de intervenção do homem em seu meio e em suas relações entre si e os demais seres vivos. Ela é representada por equipamentos, dispositivos, formas de organização do tempo e do espaço, formas de expressão e tantos outros que permitam que o ser humano possa realizar mais, que tenha maior alcance em suas tarefas e que suas ações tenham maior durabilidade e eficácia. Nessa perspectiva, as ferramentas tecnológicas oferecem a oportunidade de reconfigurarmos a rotina pedagógica, agilizando processos, conectando pessoas, facilitando a circulação de informações, gerando conhecimento e melhorando as relações interpessoais. 
A escola convive com dezenas de tecnologias novas e velhas, analógicas e digitais: quadro negro, quadro branco, lousa digital; giz, pincel, canetas digitais; grades horárias; currículos; máquina de escrever, computadores, notebooks; livros, tablets, smartphones, entre outras. Até mesmo a organização humana pode ser vista como fruto da tecnologia, do pensamento aplicado à evolução.

Todavia, neste trabalho, como estamos investigando a inserção de uma máquina na rotina escolar, nos ateremos apenas aos meios eletrônicos de processamento digital. Como foi registrado por Gianolla (2006), é tarefa fácil evidenciar a presença de tais dispositivos se observarmos o vocabulário utilizado por docentes no cotidiano escolar e seus comportamentos sociais alterados pela presença tecnológica. Atualmente, já não são estranhas as palavras e-mail, download, scannear, blog, maximizar, digitalizar, deletar, e até mesmo de outras sem significado expresso em dicionários, como "photoshopar" (modificar uma imagem no programa Adobe Photoshop).

Neste ponto, temos a compreensão de como trataremos e entenderemos 0 termo tecnologias digitais e como elas se apresentam no cotidiano da escola, modificando relações e estabelecendo novos desafios. No entanto, é preciso ressaltar que há possibilidade de que alguns(algumas) docentes não estejam inseridos(as) ou integrados(as) neste modelo de utilização pedagógica e não reconheçam sua contribuição.

Esta investigação poderá contribuir para a compreensão do uso didático desse dispositivo tecnológico (tablet educacional), que, somada às demais pesquisas sobre o uso de outras ferramentas tecnológicas em contexto escolar, poderá se tornar fonte de reflexão para futuros programas de inclusão digital e práticas pedagógicas inovadoras.

\section{2}

A QUESTÃO DA APROPRIAÇÃO DIDÁTICA

O contexto social, aliado a observações do cotidiano, nos indica que a apropriação social dos equipamentos tecnológicos, principalmente para usos comunicacionais, já está estabelecida pelas pessoas no convívio urbano. Mas, estamos buscando, neste trabalho, entender outro tipo de apropriação, aquela de 
cunho didático-pedagógico. Dessa forma, é preciso resgatar o conceito e os sentidos da palavra "apropriação", para que, em momento oportuno, possamos realizar cruzamentos que nos permitam identificar o uso ordinário e o uso didáticopedagógico.

A primeira definição resgatada é a de Ferreira (2000, p. 54), para quem apropriação é "tomar como seu; tomar como próprio; conveniente; adaptar; apoderar-se". Nascentes (1998, p. 57) define apropriação como "ato ou efeito de apropriar; acomodação; adaptação".

Posto isto, o(a) docente que recebeu o tablet educacional, ferramenta em discussão, não tem posse, tem concessão para uso. Um termo é assinado e o(a) professor(a) se compromete a usá-lo para fins pedagógicos. O tablet educacional é patrimônio da Secretaria de Estado de Educação do Distrito Federal (SEEDF) e, já que estamos discutindo questões referentes à apropriação no sentido de "ter posse", "tomar posse", os(as) docentes podem não estabelecer uma relação mais autônoma e livre com a ferramenta por esse motivo. Porém, somente por meio do uso correto dos instrumentos de pesquisas, seguido de uma análise pormenorizada da questão, poderemos confirmar ou não se esse tipo de apropriação interfere no pleno uso do tablet educacional.

Outro ponto é o da acomodação, da adaptação. Este remete ao fato de fazer com que a ferramenta seja inserida na rotina comum do(a) docente, ou seja, que seu uso seja, ou se torne, natural nos afazeres diários. Que ele(a) possa enviar e-mails particulares e institucionais, que possa interagir virtualmente com amigos e colegas de trabalho, bem como com estudantes, que ele(a) possa ler notícias gerais, preencher seu diário, entre outras ações pessoais e profissionais. Mas vale registrar que o tablet educacional é registrado no site do MEC e que existem (veremos mais adiante) normas de uso. Com essas condições, o(a) docente conseguirá acomodar, adaptar sua rotina e tarefas?

Quando o sujeito se apropria de uma ferramenta tecnológica, passa a ter o poder de reinventar em sentido simbólico o caráter funcional dos aparatos tecnológicos (RÜDIGER, 2007, p. 136). Novas relações surgem, informações interligam as pessoas, que por sua vez fazem surgir um novo tipo de inteligência, uma nova forma de conhecimento. Sobre este processo Lévy (2000b, p. 29) afirma que 
Quanto mais os processos de inteligência coletiva se desenvolvem - o que pressupõe, obviamente, o questionamento de diversos poderes -, melhor é a apropriação, por indivíduos e por grupos, das alterações técnicas, e menores são os efeitos de exclusão ou de destruição humana resultantes da aceleração do movimento tecno-social. O ciberespaço, dispositivo de comunicação interativo e comunitário, apresenta-se justamente como um dos instrumentos privilegiados da inteligência coletiva.

Assim, a apropriação das ferramentas tecnológicas acaba por gerar uma inteligência que surge pela colaboração dos sujeitos que utilizam determinada mídia de acesso e interação. Com o tablet educacional não é diferente, sua inserção na rotina escolar tem como pressuposto uma maior interação entre os sujeitos escolares. E, desta interação, uma nova forma de construção do conhecimento deveria surgir. Começaríamos, então, a ver a apropriação didática desejada.

Segundo Lemos (2010, p. 237), a dinâmica social está relacionada com a Cibercultura $^{13}$, aquela que é construída com símbolos e linguagens do mundo conectado pela internet, e ela se estabelece quando a microinformática é apropriada pela vida social. Ao discutir sobre desvio (inversão da lógica de produção e consumo das tecnologias contemporâneas) e despesa improdutiva (excesso de informação, causado pela popularização global da internet), esse autor levanta a possibilidade de que a apropriação também possa se dar como um método de improvisação, no qual os desvios do uso são responsáveis pelos desenvolvimentos da indústria da informática e por sua popularização. Além disso, ainda afirma que o espírito transgressor e desviante, falando das atitudes cyberpunks ${ }^{14}$, também é forma de apropriação. Assim,

A apropriação tem sempre uma dimensão técnica (o treinamento técnico, a
destreza na utilização do objeto) e uma outra simbólica (uma descarga
subjetiva, o imaginário). A apropriação é assim, ao mesmo tempo, forma de
utilização, aprendizagem e domínio técnico, mas também forma de desvio
(deviance) em relação às instruções de uso, um espaço completado pelo
usuário na lacuna não programada pelo produtor/ inventor, ou mesmo pelas

${ }^{13} \mathrm{O}$ termo Cibercultura é trabalhado de formas diferentes por diferentes estudiosos, entre eles, Pierre Lévy, Margaret Morse e Arturo Escobar. Neste trabalho adotamos o entendimento de Pierre Lévy, como o advento das novas mídias e como elas modificam as formas de relação da sociedade e de seus membros, ou seja, conjunto de técnicas (materiais e intelectuais), de práticas, de atitudes, de modos de pensamento e de valores que se desenvolvem juntamente com o crescimento do ciberespaço (interconexão mundial dos computadores, não apenas infraestrutura material da comunicação digital, mas também o universo de informações que ela abriga, assim como os seres humanos que navegam e alimentam esse universo) (LÉVY, 2000b, p. 17).

${ }^{14}$ Vide Cibercultura: tecnologia e vida social na cultura contemporânea, de André Lemos (2010), Editora Sulina. Em especial, o capítulo V (p. 185-198). 
finalidades previstas inicialmente pelas instituições (LEMOS, 2010, p. 239).

Rogoff (1995) discute sobre observação sociocultural, o termo apropriação. Para essa estudiosa, a apropriação tem o sentido de internalização (as pessoas e os processos culturais são externos ao sujeito, mas o contato com estes elementos faz com que ele os apreenda, tomando-os para si). Este processo é, ao mesmo tempo, social e individual, de transformação (o sujeito, ao internalizar os elementos externos, transforma-se e transforma os elementos externos em um processo de inter-relação) e de, finalmente, apropriação participativa, em que a interação social gera a negociação de sentidos em torno dos usos dos elementos. Assim, apropriação recebe o sentido de "tornar-se", sugerindo um ciclo de constante aprendizagem e modificação do pensamento e do comportamento.

Em um pensamento alinhador, Rüdiger (2013, p. 7), nos chama atenção para o uso ordinário dos aparelhos tecnológicos (apropriação ordinária) e para a exploração publicística e mercadológica da internet e suas mídias. Nesse sentido, ter um tablet, seja educacional (do programa) ou não, significaria apenas o atendimento a um frenesi, que dependendo do sujeito, suas habilidades e intenções, pode modificar sua relação com o trabalho, conduzindo-o para uma apropriação participativa.

O estudo do termo "apropriação" é de grande valia para esta investigação, pois, com base nesse entendimento é que a análise dos dados, oriundos de observações e entrevistas individuais semiestruturadas, apontará uma categorização que caracterize o uso didático da ferramenta na escola, através dos sentidos de posse, domínio, técnica, segurança, didática, participação e outros que surgiram dos discursos.

A partir dessas concepções sobre o termo apropriação, trabalharemos na construção do termo apropriação didática, aqui, inicialmente definida como uma postura pedagógica que envolve a participação ativa do(a) docente na construção de linguagens, estratégias e métodos próprios para a utilização de ferramentas que possibilitem a maximização da ação didática, promovendo ensino e aprendizagem com interatividade, imaginação e criatividade em práticas inovadoras. 


\section{3}

\section{AS FACES DA INOVAÇÃO PEDAGÓGICA}

Toda essa discussão envolve as várias dimensões da inovação (tecnológica, educacional, intelectual etc.). Trataremos brevemente das inovações, começando pela tecnológica. Segundo Rebecchi (1990), a inovação tecnológica é aquela que envolve a criação e o uso de equipamentos que maximizam o potencial de intervenção do ser humano na natureza, produzindo bens de consumo e oferecendo serviços especializados, além de desencadeia uma reorganização da estrutura de trabalho, não somente nos aspectos físicos, mas também nas condições de exercício e na postura social dos sujeitos. Para esse autor, tal dimensão da inovação gera, entre outros, perda de autonomia (o ser fica acorrentado às diretrizes técnicas, normas de uso e é obrigado a seguir o funcionamento e o ritmo do equipamento) e fantasias de próteses (cria-se uma sensação de dependência da ferramenta, o sujeito tornou-se um simples acionador de botões, pois se limita a exercer suas atribuições somente quando a máquina assim o determina).

Ferretti (1980, p. 75), ao criticar as inovações pedagógicas no Brasil de sua época, destaca, a respeito das mesmas:

a) as mudanças que têm sido observadas, no ensino brasileiro, a nível pedagógico, referem-se mais à adoção e adaptação de inovações produzidas em outros contextos do que à produção de inovações, embora esta não esteja de todo ausente;

b) no que diz respeito à adoção de inovações, esta se processa de duas formas: ou há uma tentativa de estudar mais ou menos seriamente a proposta inovadora para, então, adaptá-la e colocá-la em uso, ou prevalece uma atitude ingénua de inovar por inovar (modismo ou "folclore pedagógico");

c) quase todas as mudanças, a nível pedagógico, estão orientadas pelo "continuum" escola tradicional - escola nova, em benefício, evidentemente, do segundo polo.

São trinta e cinco anos entre as críticas de Ferretti e os dias atuais. O quanto elas ainda fazem sentido? Será que as inovações pedagógicas ainda recebem tais críticas? Nesta mesma linha de raciocínio temos Afonso (1993, p. 19), que

[...] ao analisar a tentativa de implementação de inovações no sistema de ensino de Portugal, afirma que a apropriação efetiva pelas estruturas e atores envolvidos no terreno prático de aplicação, quase nunca correspondem aos objetivos e expectativas que estiveram em sua origem. 
Para expor a discrepância existente, o pesquisador explica que existe:

a) Uma concepção de inovação contraditória, ou seja, objeto e objetivos não são compreendidos do mesmo modo pelos sujeitos sociais envolvidos;

b) Um modelo de funcionamento da inovação que não atende ao quadro funcional, aos constrangimentos institucionais e às aspirações, necessidades e preocupações individuais dos adotantes;

c) Uma estratégia de implementação da inovação que atribui diferentes papéis a uma administração central que tudo comanda e uma periferia à qual é reservada a função de aplicação daquilo que é definido.

Segundo Cunha (2008, p. 22),

[...] é preciso entender que a inovação requer uma ruptura necessária que permita reconfigurar o conhecimento para além das regularidades propostas pela modernidade. Ela pressupõe, pois, uma ruptura paradigmática e não apenas a inclusão de novidades, inclusive as tecnológicas. Neste sentido envolve uma mudança na forma de entender o conhecimento.

Neste sentido, não foi apenas considerada a inclusão de novidades e tecnologias, mas também uma mudança na forma de relação com oo conhecimento.

Ainda utilizando as condições e características descritas por Cunha (2008, p. 24-27), para a inovação em práticas pedagógicas, e inserindo-as no escopo de nossa construção, citamos: a) Ruptura com a forma tradicional de ensinar e aprender (os dispositivos tecnológicos contemporâneos e as mídias sociais de comunicação demandam uma ressignificação das relações no cotidiano escolar, assim, as formas tradicionais de ensino e aprendizagem podem ter sua eficácia comprometida); b) Gestão participativa (participação na experiência desde a concepção até a análise dos resultados); c) Reconfiguração de saberes (abandono das estratificações dualistas entre saberes: científico-popular, educação-trabalho, objetividade-subjetividade etc.); d) Reorganização da relação entre a teoria e a prática (contempla a leitura da realidade, valoriza os saberes construídos pelo grupo de trabalho, possui visão interdisciplinar); e) Percepção orgânica no processo de concepção, desenvolvimento (faz referência à apreensão das relações entre as decisões pedagógicas que acompanham todo o processo de ensinar e aprender, busca da coerência entre os objetivos, o desenvolvimento e a avaliação das ações); f) Mediação (inclusão das relações socioafetivas como condição da aprendizagem significativa, reconhecimento dos significados atribuídos e a compreensão da 
historicidade de sua produção); g) Protagonismo (rompimento com a relação sujeitoobjeto historicamente proposta pela modernidade, reconhecimento dos sujeitos ativos nas práticas pedagógicas).

E, finalizando este tópico de discussão, temos Correia (1991, p. 36), que afirma que a inovação, por mais modesta que seja, rompe um equilíbrio, cria uma situação de crise, que nos leva à inovação nos contextos de ação.

Todas essas perspectivas de inovação fazem surgir, por romperem com um delicado equilíbrio ou provocarem um ligeiro desconforto, a necessidade de outra formação docente, de uma formação profissional que contemple novas habilidades e produza uma visão interdisciplinar e reflexiva do cotidiano escolar, de suas ferramentas e seus sujeitos. A próxima discussão encaminhará nosso pensamento para a aprendizagem do professor e da professora.

\section{4}

FORMAÇÃO DOCENTE PARA USO DAS TDICE

Franco (2013, p. 26) menciona uma geração que nasceu cercada pela tecnologia digital e, obviamente, está mais disposta a utilizá-la em suas relações com o mundo e com as pessoas. Para se referir a essa geração, esse autor prefere o termo "nativo digital", cunhado por Marc Prensky, em 2001.

Assim, tendo como base essa geração de nativos digitais e sua presença cada vez maior nas escolas, cabe o questionamento sobre como estes indivíduos estabelecerão comunicação e conviverão com os docentes, que podem não conhecer sua linguagem, ter medo de suas ferramentas e relutância em aprender a reaprender.

Para Prensky (2001), os nativos digitais são jovens que utilizam com naturalidade a linguagem digital, ou seja, estão imersos na tecnologia e usam ferramentas digitais, entre elas e, principalmente, as redes sociais. Mas o que o(a) professor(a) pode fazer nesse novo contexto? A resposta mais lógica seria: continue navegando. Mas basta somente isso?

Lacerda Santos (2010, p. 22), em seu estudo, registra que os professores consideram que a Sociedade Informacional é um fato inquestionável e incontornável, portanto, os(as) estudantes serão também reflexo deste movimento. 
As discussões que tivemos até agora constroem um cenário que acaba por compelir o(a) docente a buscar uma formação que também envolva o entendimento e o uso de tecnologias digitais, na compreensão de que, a cada segundo a computação torna-se ubíqua (WEISER, 1999), ou seja, mais entranhada na vida das pessoas, tornando sua presença praticamente invisível, porém vital para o funcionamento da sociedade.

Lacerda Santos (2014, p. 530) retrata a situação do(da) docente neste contexto de rede emaranhado:

\begin{abstract}
O professor, colocado na situação de "conectado", deve compreender o papel e o potencial pedagógico das Tecnologias Digitais de Informação, Comunicação e Expressão (TDICE), assim definidas justamente por serem suportes privilegiados e inovadores para que nos informemos com mais intensidade, para que nos comuniquemos com mais agilidade e para que nos expressemos com mais liberdade. No contexto de uma rede social como a escola, os impactos são contundentes. O professor deve, portanto, percebê-las e assimilá-las como meios didáticos poderosos para a dinamização de suas ações educativas, para o estabelecimento de conexões com o cotidiano dos alunos, para acirrar a pertinência da escola no contexto de uma sociedade cada vez mais digital, cada vez mais centrada na exploração dessas tecnologias em todos os setores da ação humana e, por fim, para promover aproximações entre eles próprios e as manifestações culturais emergentes no ambiente escolar, decorrentes da exploração dessas tecnologias, tão presentes na vida cotidiana de seus alunos e também dos próprios professores, os quais, por força de diversas circunstâncias, têm se tornado cidadãos de dois mundos: o mundo conectado, fora da escola, e o mundo da comunicação linear, dentro da escola.
\end{abstract}

A partir desse momento juntam-se à discussão questões sobre a formação docente, principalmente voltada para o uso pedagógico da tecnologia educacional, aqui entendida como técnica, ferramentas tecnológicas e, sobretudo, posicionamento didático perante a complexidade dos processos pedagógicos.

Sampaio e Leite (2004) insistem na alfabetização tecnológica do professor, justificando sua necessidade na inserção do(a) docente na sociedade da informação, alegando que a democratização do conhecimento, a produção, a interpretação das tecnologias, suas linguagens e consequências, somente terão eficácia no ensino se aqueles que a conduzem cotidianamente nas salas de aula estiverem totalmente imersos neste contexto e cenário. O que coaduna com os pensamentos até aqui expostos. 
Para Garcia (1999), um programa de formação docente deve prestigiar o caráter de escuta docente e de continuidade, objetivando a emancipação dos profissionais, assim propiciando a inovação pedagógica.

Mas, como nos alerta Lacerda Santos (2014), a maioria dos cursos de licenciatura sequer oferecem disciplinas relacionadas com as tecnologias educativas. Acrescenta ainda que nem mesmo os(as) docentes dos centros formadores de profissionais para o exercício do Magistério utilizam de forma inovadora as TDICE em suas aulas, privando os estudantes, futuros professores e professoras, de exemplos positivos de apropriação didática dos dispositivos e das tecnologias digitais.

Lacerda Santos, em entrevista ao Canal Último Segundo ${ }^{15}$, critica a falta de disciplinas nos cursos de graduação, o que por si só poderia ser objeto de estudo. Ele ainda acrescenta que:

Os professores em exercício não foram preparados para usar tecnologias
digitais em sala e os que ainda estão na graduação também não estão
sendo preparados. A educação continuada não resolve uma falha de
formação inicial. As faculdades de educação das universidades deveriam
ser verdadeiros laboratórios de inovação pedagógica.

Neste ponto voltamos nosso olhar para a formação dos docentes, mais especificamente para a formação permanente em serviço, que, conforme Demo (2006, p. 31-48), apresenta sentidos (rompimento com épocas formais de formação; aprendizagem formativa e dinâmica; dialética com imprevisibilidade; relação íntima entre teoria e prática; exercício do pensamento crítico e criativo; liberdade de intervenção, de criação; estabelecimento claro dos processos e do ponto aonde se quer chegar).

Outra visão sobre formação docente é apresentada por Perrenoud (2000, p. 125-140). Para este estudioso, o(a) professor(a) precisa desenvolver competências para o pleno exercício de sua profissão. Entre essas competências, figura a utilização das novas tecnologias para ampliar o campo de ação docente.

Após tal exposição, acreditamos que este arcabouço teórico ofereça o suficiente para analisarmos as informações dos textos de pesquisa e partirmos para reflexões vindouras. Ao passo que a discussão assim exigir, outras linhas de

15 Fonte: <http://ultimosegundo.ig.com.br/educacao/2013-08-22/professor-e-chave-para-o-sucessono-uso-de-tecnologia-na-sala-de-aula.html . Acesso em: 08 set. 2013, às 11h55min. 
pensamento serão incluídas objetivando ampliar a compreensão do uso do tablet educacional como ferramenta pedagógica. 
3

O CENÁRIO PARA INSERÇÃO DAS TDICE NA ESCOLA

Vários estudos contribuem para que possamos contemplar as condições objetivas de inserção das TDICE nas escolas. Nesta etapa do trabalho discutiremos sobre questões de infraestrutura (acesso à internet), configuração do tablet educacional, formações para o uso dos dispositivos tecnológicos e sobre programas similares cujos objetivos foram gerar a inclusão digital de professores(as), bem como verificar como tais aspectos se apresentaram ao professorado.

\section{1}

O PROGRAMA NACIONAL DE TECNOLOGIA EDUCACIONAL (PROINFO)

O Programa Nacional de Informática na Educação ${ }^{16}$ foi criado pela Portaria n. ${ }^{\circ}$ 522, de 09 de abril de 1997, com a finalidade de promover o uso da tecnologia como ferramenta de enriquecimento pedagógico no ensino público do Brasil, no Ensino Fundamental e no Ensino Médio. No dia 12 de dezembro de 2007, o Decreto n. ${ }^{\circ} 6.300$ modifica o nome para Programa Nacional de Tecnologia Educacional ${ }^{17}$, tendo como objetivo promover o uso pedagógico das tecnologias de informação e comunicação na rede pública de Educação Básica.

Uma das ações do Prolnfo é o uso do tablet no ensino público pelos(as) professores(as). Para recebimento da ferramenta é preciso ser escola urbana de Ensino Médio, ter internet banda larga, laboratório do Prolnfo e rede sem fio (wi-fi).

Os estados, para serem incluídos nesta ação, precisavam aderir ao Plano de Ações Articuladas $(\mathrm{PAR})^{18}$. Após a aprovação, o Fundo Nacional de Desenvolvimento da Educação (FNDE) repassa os recursos para os estados. Então os governos estaduais podem adquirir os tablets das empresas vencedoras do pregão, no caso a CCG Digibras e a Positiva Informática.

\footnotetext{
16 Endereço eletrônico <http://www.fnde.gov.br/programas/programa-nacional-de-tecnologiaeducacional-proinfo>.

${ }^{17}$ Endereço eletrônico < http://portal.mec.gov.br/proinfo/proinfo>.

${ }^{18}$ Maiores informações em <http://portal.mec.gov.br/par>.
} 
No DF a distribuição oficial para os(as) docentes aconteceu no dia 23 de maio de 2013, no Centro de Convenções Ulisses Guimarães.

\section{2}

\section{O QUE PENSAM E O QUE SABEM OS(AS) DOCENTES SOBRE AS TDICE}

Moscovici (1978, apud LACERDA SANTOS E BRAGA, 2012, p. 45) insere nesta discussão as representações sociais dos indivíduos, que segundo ele, têm grande função simbólica e um enorme poder de construção da realidade objetiva, ou seja, o posicionamento do docente perante as TDICE pode resultar em intervenções pedagógicas problemáticas e experiências traumáticas que, inclusive, inviabilizam o sucesso do trabalho e futuras aproximações e apropriações.

A recusa, o medo e a sedução também foram percebidos por Gianolla (2006, p. 55) com relação ao uso do computador por professores(as). Com o tablet, os sentimentos não são tão diferentes do descrito pela autora. Em visita a um Centro de Ensino Médio (CEM) de Santa Maria/ DF, poucos dias depois da entrega do tablet aos docentes, interpelamos uma professora sobre o porte e uso do tablet. Ela foi taxativa: "Venho de ônibus e tenho medo de levarem [de ser roubado] ou até mesmo de quebrar, cair no chão ou qualquer coisa assim". Logo em seguida, veio a explicação superficial sobre tamanho receio: "Esse negócio nem é meu, se quebrar ou sumir talvez tenha de pagar por ele. E eu nem escolhi [o modelo do tablet ou até mesmo se realmente esse tipo de ferramenta supre suas necessidades]". Os tablets ficam sob a responsabilidade do professor(a), mas são patrimônio da SEEDF. Nesse momento ressaltamos que a escolha de ferramentas didáticas deve passar pelo crivo do professor, de seu discernimento sobre o que é essencial ao seu trabalho didático-pedagógico (LACERDA SANTOS, 2010, p. 24-25).

Silva (1997) realizou uma pesquisa sobre os reflexos do uso do computador na prática docente e as observações foram similares às registradas por Lacerda Santos e Braga (2012) e Gianolla (2006), mesmo tendo uma diferença de 9 e 15 anos entre as observações, respectivamente. Mas o que pode ter acontecido para que não estivéssemos preparados para o tablet?

Ferreira (2009), em seu estudo sobre formação docente e inclusão digital para docentes, indica que $83,33 \%$ dos professores sabem utilizar o computador; $72 \%$ 
utilizam com frequência o computador para planejar suas aulas; e $77 \%$ afirmam que o trabalho pedagógico ficou mais fácil. Esse dado se deve, em parte, à aquisição de equipamentos pessoais e uso dos mesmos fora do ambiente escolar.

Gianolla (2006, p. 56) relata que a sensação de fazer algo errado e estragar a máquina é muito forte. Em nossa pesquisa temos dados semelhantes a esses, pois durante o período de aproximação dos colaboradores da pesquisa (docentes regentes do Ensino Médio), depoimentos alinhados a este pensamento surgiram com frequência, bem como relatos da fragilidade do aparelho.

\section{3}

\section{A ESTRUTURA DAS ESCOLAS PARA O USO DO TABLET EDUCACIONAL}

Falcão (2012) relata as dificuldades na realização da sua pesquisa, devido à estrutura deficiente nas escolas (sem ligação elétrica para computadores, mau funcionamento, falta de manutenção, má formação etc.). Por se tratar de tablets educacionais, tais dispositivos têm maior mobilidade do que os PC ou até mesmo notebooks. Assim, das escolas espera-se que forneçam internet sem fio (wi-fi).

A rede pública de ensino do DF é atendida pelo Programa Banda Larga nas Escolas $^{19}$, e, segundo dados na SEEDF, 92\% das instituições educacionais têm internet banda larga. Um dos requisitos para a escolha do local de investigação foi haver internet sem fio (conexão wi-fi) disponível para uso dos(das) docentes. Acreditávamos que esta não seria uma dificuldade, mas fizemos também levantamento sobre tal disponibilidade (qualidade do sinal, estabilidade, velocidade etc.), mesmo não sendo o foco da investigação.

Um dos pressupostos para o trabalho com o tablet educacional é que o mesmo esteja conectado à internet e, então, o(a) professor(a) possa baixar os conteúdos específicos para o trabalho com o dispositivo, além, é claro, de estabelecer uma comunicação mais eficiente com seus pares e seus estudantes.

\footnotetext{
19 Maiores informações em: <http://www.fnde.gov.br/programas/programa-nacional-de-tecnologiaeducacional-proinfo/proinfo-programa-banda-larga-nas-escolas-pble>. Acesso em: 13 abr. 2015, às $15 \mathrm{~h} 20 \mathrm{~min}$.
} 


\section{4}

\section{CONFIGURAÇÃO DO TABLET EDUCACIONAL}

Acreditamos que a configuração do dispositivo se torna algo muito relevante para sua apropriação como ferramenta didática, pois é possível que o(a) professor(a) já esteja familiarizado(a) com o sistema operacional, devido ao uso de smartphones ou mesmo tablet regulares de outras marcas ou modelos adquiridos com recursos pessoais. $E$ ainda, que o(a) mesmo(a) não consiga trabalhar com a ferramenta didática por conta de suas possíveis limitações técnicas. A investigação indicou se a configuração é ou não é facilitadora ou impeditiva para o uso pedagógico.

O tablet educacional, adquirido com recursos do MEC e do GDF, possui duas configurações básicas, segundo seus fabricantes; são elas:

- Modelo de Tablet Tipo 1

Tela: LCD de 7 polegadas tipo touch multitoque capacitivo, resolução de 1024 x 600 pixels, formato $16: 9$

Sistema operacional: Android 4.0, Português Brasil

Processador: $1 \mathrm{GHz}$

Armazenamento: 16GB (com possibilidade de expansão de até 32GB com cartão Micro SD Card)

Conectividade: Rede sem fio IEEE $802.11 \mathrm{~b} / \mathrm{g} / \mathrm{n}$ e Bluetooth 2.1 + EDR

Câmeras: Frontal VGA e traseira de 2,0MP

Medidas: $196 \times 120 \times 11,4 \mathrm{~mm}(\mathrm{LxAxP})$

Peso: $398 \mathrm{~g}$ (sem a capa emborrachada)

- Modelo de Tablet Tipo 2

Tela: LCD de 9,7 polegadas tipo touch multitoque capacitivo, resolução de $1024 \times 768$ pixels, formato 4:3

Sistema operacional: Android 4.0, Português Brasil

Processador: $1 \mathrm{GHz}$

Armazenamento: 16GB (com possibilidade de expansão de até 32GB com cartão Micro SD Card) 
Conectividade: Rede sem fio IEEE $802.11 \mathrm{~b} / \mathrm{g} / \mathrm{nTM}$ e BluetoothTM $2.1+$ EDR

Câmeras: Frontal VGA e traseira de 2,0MP

Medidas: $242 \times 186,1 \times 10,8 \mathrm{~mm}(\mathrm{LxAxP})$

Peso: $606 \mathrm{~g}$ (sem a capa emborrachada)

Figura 1 Tablet Educacional

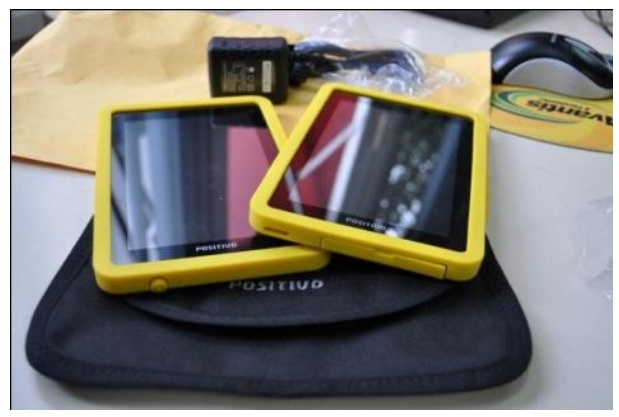

Fonte: http://www.sed.sc.gov.br/

\section{5}

\section{O CURSO DE FORMAÇÃO PARA O USO DA FERRAMENTA DIDÁTICA}

A apropriação didática e pedagógica da ferramenta pode se dar também pela formação que o(a) docente recebe de seu órgão superior. Para isso, a SEEDF ofereceu, através da Escola de Aperfeiçoamento dos Profissionais da Educação (EAPE), o curso intitulado "Tablet Educacional como Ferramenta Pedagógica" ${ }^{20}$, no período de agosto de 2013 a novembro de 2013, na modalidade a distância (apenas quatro encontros presenciais). Foram oferecidas 3.051 (três mil e cinquenta e uma) vagas, divididas em 84 (oitenta e quatro) turmas, com 35 (trinta e cinco) cursistas cada. $\mathrm{O}(\mathrm{A})$ docente poderia se candidatar a vaga se fosse regente ou coordenador pedagógico em instituições educacionais de Ensino Médio e se tivesse optado por receber o tablet educacional. Docentes que lecionassem em Centro de Ensino Médio que adotaram a semestralidade tiveram preferência. A carga horária do curso é de 90 (noventa) horas (12 horas presenciais + 78 horas em ambiente virtual).

O curso tinha como objetivo geral proporcionar a formação continuada de professores da rede pública de ensino para o uso didático e pedagógico das

\footnotetext{
${ }^{20}$ Maiores informações em <http://www.eape.se.df.gov.br/images/pdfs/Apresentaca0\%20Tablet\%20.pdf>. Acesso em: 15 maio 2015, às 21h14min.
} 
tecnologias da informação e da comunicação (TIC), com foco na utilização dos tablets. Os encontros presenciais ficaram a cargo dos Núcleos de Tecnologia Educacional (NTE) de cada Coordenação Regional de Ensino (CRE).

Os temas abordados e as respectivas datas foram ${ }^{21}$ :

- 06 a 08 de agosto de 2013: TIC; Fundamentação básica e teórica do uso dos tablets;

- 03 a 05 de setembro de 2013: Tablets/ Recursos básicos;

- 01 a 03 de outubro de 2013: Tablets/ Recursos pedagógicos;

- 05 a 07 de novembro de 2013: Tablets/ Recursos avançados.

Cabe ressaltar que apenas 1.372 (mil trezentas e setenta e duas) vagas foram preenchidas, das 3.051 (três mil e cinquenta e uma) disponíveis. E apenas 98 (noventa e oito) docentes concluíram o curso, o que corresponde a $7,14 \%$ do total de inscritos.

Este dado por si só já é motivo de investigação, pois como podemos justificar um índice tão pequeno de sucesso? Algo deve ter motivado os(as) docentes a desistirem do curso. O Relatório Final de Curso (anexo 02), datado de 27 de março de 2014, aponta algumas causas possíveis:

- A compulsoriedade (ter condicionado a aceitação do tablet educacional à inscrição no curso de formação, sem oferecer opções de início);

- O período de realização do curso aconteceu no último semestre (Em geral o último semestre é repleto de eventos e atividades que acabam por ocupar demais o corpo docente);

- Excesso de formações ofertadas aos docentes (o curso foi anunciado após o calendário oficial da EAPE. Os professores já podiam estar matriculados em outros cursos da mesma instituição promotora).

A formação docente supracitado foi abordada pelo participantes dessa pesquisa e analisada para que pudéssemos ampliar as possibilidade de entendimento da apropriação didática das TDICE, em especial do tablet educacional.

\footnotetext{
${ }^{21}$ Tais datas referem-se à primeira turma, a cada semestre, desde então, são oferecidas, em média, 150 (cento e cinquenta) vagas.
} 


\section{4}

\section{O OLHAR E O MÉTODO}

Nesta etapa, trataremos de demarcar nossa investigação epistemologicamente, anunciando como enxergaremos nosso objeto de pesquisa, o processo de apropriação do tablet educacional pelos(as) docentes da Rede Pública de Ensino do DF. Trataremos também da linha de norteadora do trabalho, definindo o método, as estratégias, os instrumentos e os colaboradores de pesquisa.

\section{1}

\section{A PESQUISA QUALITATIVA}

Esta investigação caracteriza-se como de natureza qualitativa, pois se deterá em informações expressas em palavras orais e escritas e abstrações de observações diretas de posturas e comportamentos dos colaboradores de pesquisa. Moreira (2004, p. 57) cita algumas características básicas da pesquisa qualitativa:

a) Foco na interpretação: o pesquisador tem especial interesse na interpretação que os próprios colaboradores de pesquisa têm da situação sob estudo;

b) Ênfase na subjetividade: interesse na perspectiva dos participantes, em sua relação com as pessoas, com o conhecimento e com as ferramentas disponíveis;

c) Flexibilidade no processo de condução da pesquisa: por trabalhar com situações por vezes complexas, a definição exata dos caminhos de investigação se torna difícil, assim o pesquisador necessitará refletir sobre a melhor estratégia de aproximação do fenômeno;

d) Orientação para o processo e não para o resultado: a ênfase está no entendimento e não em um objetivo ou objeto predeterminado;

e) Preocupação com o contexto: a situação e o comportamento das pessoas estão interligados, influenciando mutuamente a experiência vivida; 
f) Reconhecimento do impacto do processo de pesquisa sobre a situação de pesquisa: aqui admitimos que o pesquisador influencia a situação pesquisada e é por ela influenciado.

Ainda conforme Moreira (2004, p. 59), a pesquisa qualitativa foca no ser humano enquanto agente, e cuja visão de mundo é o que realmente interessa. Assim, procuramos analisar os processos que se apresentam como unidades já formadas, considerando seu constante fluxo. Portanto, visaremos a apreensão, a análise e a descrição do fenômeno que se dá à nossa consciência e ciência.

\section{2}

\section{O ESTUDO DE CASO PARA ROBERT STAKE}

A abordagem metodológica de Stake (2012, p. 18) entende o caso como algo específico, como algo complexo e em funcionamento. Smith (1979 apud STAKE 2012, p. 18) entende o caso como um sistema limitado, sua complexidade se estende apenas ao próprio objeto de pesquisa. Mas lembra que o caso é um sistema integrado, e mesmo que suas partes não estejam em pleno funcionamento elas continuarão a estabelecer relação com as demais partes.

Sendo este estudo uma tentativa de compreensão global a partir de um caso específico, esta investigação caracteriza-se como um estudo de caso instrumental, o que nos leva à obrigação de compreender, dentro de um contexto e de uma série de requisitos, o caso que melhor ilustre o fenômeno. Para tal, Stake (2012, p. 20) sugere alguns critérios de seleção de casos:

a) Possibilidade de maximizarmos o que podemos aprender (o caso terá possibilidade de nos levar a entendimentos, a asserções sobre o fenômeno);

b) É de fácil acesso e acolhe a investigação (processo ágil de identificação de colaboradores mais dispostos a participar).

Observando os critérios acima, a seleção dos casos (os(as) docentes) foi feita por convite via correio eletrônico. Desta maneira, docentes de todas as Coordenações Regionais de Ensino poderiam participar da pesquisa. E sendo assim, só participariam do trabalho aqueles que realmente desejassem contribuir para a compreensão desse fenômeno. 
Stake (2012, p. 23) acredita que em estudos de caso dificilmente teremos novas generalizações, 0 que alcançaremos com mais frequência é o aperfeiçoamento de uma generalização. Porém, serão possíveis várias microgeneralizações, principalmente sobre os motivos que fazem com que os(as) docentes aceitem ou não a ferramenta didática, sobre os tipos de apropriação e os usos no cotidiano escolar, apesar de ressaltar que o verdadeiro objetivo do estudo de caso é a particularização, não a generalização (2012, p. 24), como menciona abaixo:

Pegamos num caso particular e ficamos a conhecê-lo bem, numa primeira fase não por aquilo em que difere dos outros, mas pelo que é, pelo que faz. A ênfase é colocada na singularidade e isso implica o conhecimento de outros casos diferentes, mas a primeira ênfase é posta na compreensão do próprio caso.

Podemos dizer acerca das asserções que são uma mistura escondida de experiência pessoal, trabalho acadêmico e asserções de outros investigadores. Mas para chegarmos a este ponto precisamos compreender que o estudo de caso é paciente, reflexivo e disponível. O estudo de caso de Stake (2012) procura preservar as múltiplas realidades, as perspectivas diferentes e até contraditórias do caso, do fenômeno. Neste sentido, queremos analisar a singularidade e a complexidade do caso, sua articulação e interação com o contexto no qual está inserido.

Durante o trabalho com o estudo de caso o investigador adapta suas técnicas e acomoda sua visão para o contexto, assim, modifica seu pensamento e, consequentemente, sua forma de investigar. Lançando nosso olhar para o futuro, produziremos um relatório de pesquisa, ou seja, anotações reflexivas feitas durante o exercício de investigação, contendo os métodos utilizados e suas adaptações, bem como os motivos para tal, facilidades e dificuldades encontradas no trabalho com 0 estudo de caso. Com esta iniciativa espera-se contribuir para o aprimoramento do método e a formação metodológica de investigadores vindouros. 


\section{3}

COLABORADORES DE PESQUISA

Após os(as) colaboradores(as) de pesquisa terem manifestado o desejo de participar, o local de exercício desses(as) docentes passa a ser também investigado, principalmente quanto às suas práticas mediadas pelas tecnologias e seu Projeto Político-Pedagógico (PPP).

A decisão de incluir todos(as) os(as) docentes inscritos(as) no curso de formação se dá pelo objetivo traçado e pela estrutura adotada como estratégia de abordagem do conhecimento. Somente será possível entendermos o processo de apropriação do tablet educacional se conhecermos os motivos de recusa ou aceitação da ferramenta.

Foi realizado um mapeamento institucional para termos acesso aos dados gerais de caracterização dos colaboradores da pesquisa, entre eles: gênero, idade, tempo de serviço, formação para uso de TDICE etc.

$O$ cruzamento desses dados com aqueles que revelam o processo de apropriação de ferramentas didáticas pode contribuir para a elucidação de nosso objetivo geral.

\section{4}

\section{A ESTRUTURA DA PESQUISA: NÍVEIS DE APROFUNDAMENTO}

No primeiro momento da investigação, nível geral, todos(as) os(as) docentes puderam participar da investigação respondendo ao questionário geral, contendo perguntas sobre gênero, idade, tempo de serviço, se possuem curso para uso de TDICE na educação. Essa etapa serviu como caracterização dos colaboradores. Constou neste momento também o aceite ao Termo de Consentimento Livre e Esclarecido (TCLE) on-line.

$\mathrm{Na}$ etapa seguinte, chamada de nível 1, ou seja, o início da pesquisa em si, todos(as) os(as) docentes responderam questões acerca do conhecimento prévio da linguagem utilizada no tablet educacional e sobre a utilização de dispositivos tecnológicos em sua rotina pessoal. Logo em seguida, buscamos saber se eles(as) 
aceitaram receber ou não a ferramenta didática fornecida pelo GDF, justificando sua resposta. A partir deste ponto tivemos, dependendo das respostas fornecidas, o encerramento da participação.

As perguntas do nível 2 questionaram os(as) docentes sobre a posse do tablet, pois eles(as) podem tê-lo recebido, mas devolvido logo em seguida. Nosso objetivo foi saber os motivos que levaram o(a) docente a ficar ou a devolver o dispositivo.

O nível 3 concentrou a maior parte de nosso trabalho, pois é nele que verificamos o tipo de apropriação do tablet. Se o(a) docente o recebeu e ficou com ele, procuramos saber como a ferramenta foi utilizada em sua rotina pedagógica, em seu cotidiano. Aqui procuramos saber, entre outros, se o(a) professor(a) participou do curso oferecido pela EAPE, se o concluiu, se as experiências anteriores com outras ferramentas influenciou a aceitação da atual, que atividades são mais comuns no uso do tablet, se ele(a) percebeu alguma melhoria em seu trabalho, em sua rotina, na abstração do conhecimento, na relação com os demais sujeitos escolares etc.

A última etapa da pesquisa foi realizada com aqueles que receberam, ficaram e usam o tablet educacional. Para estes, realizamos uma entrevista semiestruturada, com posterior transcrição e análise de seu conteúdo.

A figura abaixo ilustra o pensamento proposto nessa estrutura de investigação.

Figura 2 - Estrutura da pesquisa

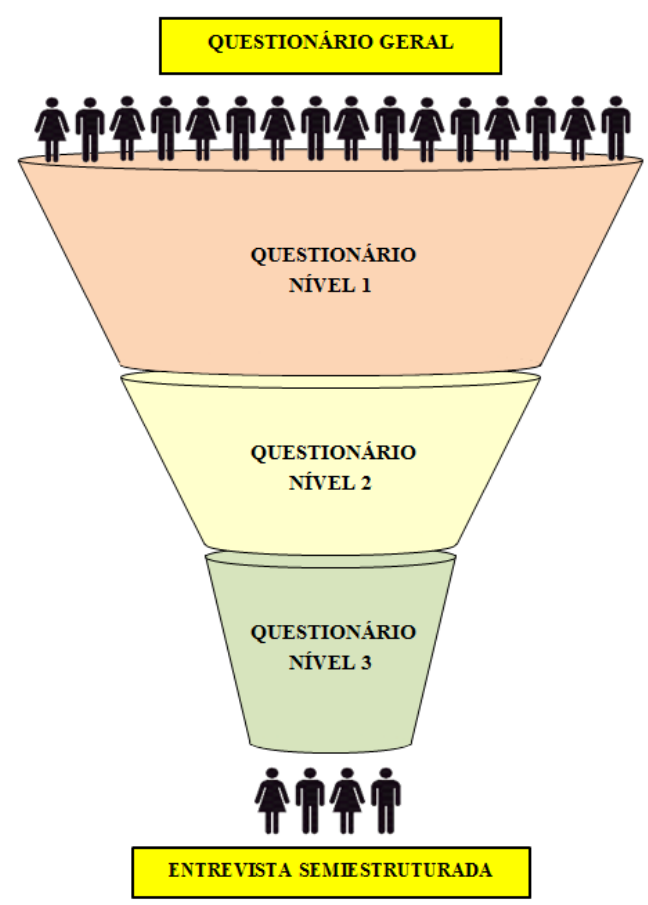




\section{5}

\section{ESTRATÉGIAS DE INVESTIGAÇÃO}

Segundo Stake (2012, p. 65), a coleta de dados tem início antes do compromisso de realizar o estudo: contextualização, familiarização com outros casos, primeiras impressões etc. Para este estudioso, a experiência é a base para um bom estudo de caso. E a experiência, acrescida de boas fontes, conduzirá o trabalho e imprimirá qualidade do mesmo.

O tempo é sempre escasso. Assim, precisávamos maximizar as possibilidades de investigação, suas estratégias e instrumentos. Para que pudéssemos agilizar a pesquisa precisávamos identificar colaboradores, conhecer sua rotina, selecionar fontes de pesquisa e até mesmo fontes de despesas.

Posto isto, após a identificação dos(as) docentes para a pesquisa, através da livre manifestação, a documentação foi providenciada a fim de que tivéssemos autorização da SEEDF para iniciarmos o trabalho. Além dessa etapa legal, fizemos visitas ao CEM para apresentação do projeto e do pesquisador, bem como para o reconhecimento da rotina das pessoas e sua disposição para a participação. Esta ação nos aproximou das pessoas, tornando nossa presença algo normal, corriqueiro, o que contribuiu para uma observação natural dos processos.

Passada esta etapa, estávamos prontos para o contato direto com as pessoas, nossos colaboradores de pesquisa. Primeiramente, solicitamos por escrito autorização para recolha e uso do material, deixando o(a) colaborador(a) seguro(a) quanto à confidencialidade e sigilo.

A partir desse momento passamos à aplicação dos questionários.

\subsection{1}

\section{O questionário on-line}

O questionário alinhou-se aos objetivos da investigação, dando ênfase aos motivos da aceitação/rejeição e a percepção sobre uma possível mudança na rotina pedagógica. O questionário pode ser realizado on-line com auxílio do próprio tablet educacional, por computador de mesa, notebook ou, até mesmo, smartphone. No e- 
mail que apresentava a pesquisa, o pesquisador explanava os objetivos do trabalho, o(a) docente recebeu um link para acesso às perguntas e teve a opção de responder pela ferramenta pedagógica ou em outro dispositivo de sua preferência. $O$ questionário foi preenchido livremente, dando autonomia de tempo e de local para seu preenchimento. Devido a essas características, o questionário on-line facilitou o prosseguimento da investigação à última etapa, a entrevista semiestruturada. Fase que focou nas questões de uso, mau uso e desuso pedagógico. A estrutura do questionário on-line está exposta no apêndice $\mathrm{C}$.

Nas questões subjetivas uma aba se abria para que o(a) docente registrasse seu pensamento de forma escrita ou falada. Ao proceder com essa investigação imaginamos como o pesquisador poderia se apropriar didaticamente das ferramentas tecnológicas. Daí surgiu a ideia de utilizarmos um questionário on-line, que, entre outras vantagens, ofereceu ao docente a opção de pausar o preenchimento e depois voltar para o mesmo ponto de pausa, podendo ainda escrever usando um teclado virtual ou simplesmente dizer a resposta que o dispositivo escreveria. Esta escolha também determinou a apropriação didática do instrumento de pesquisa pelo pesquisador.

Abaixo, temos um quadro que indica a relevância das questões para 0 cumprimento dos objetivos específicos, consequentemente, do objetivo geral, bem como para posteriores análises que também contribuíram para a reflexão da apropriação didática de dispositivos digitais.

\begin{tabular}{|c|l|}
\hline \multicolumn{2}{|c|}{ Questionário Geral } \\
\hline Questão 1 & $\begin{array}{l}\text { Esta questão indicou a CRE de origem dos(as) } \\
\text { colaboradores de pesquisa, oferecendo um mapa sobre a } \\
\text { participação neste trabalho e, possivelmente, de uso didático } \\
\text { do tablet educacional, tendo em vista que também houve } \\
\text { maior índice de conclusão do curso nas turmas de formação } \\
\text { do lado sul do DF. }\end{array}$ \\
\hline Questão 2 & $\begin{array}{l}\text { Estabelece relação com o curso de graduação do professor e } \\
\text { uma possível formação docente para uso da TDICE. } \\
\text { Posteriormente, este dado foi cruzado com a questão 5 do } \\
\text { questionário geral, bem como demais questões dos níveis 1, } \\
\text { 2 e 3, podendo indicar uma tendência de formação para uso }\end{array}$ \\
\hline
\end{tabular}




\begin{tabular}{|c|c|}
\hline & de TDICE em determinados cursos. \\
\hline Questão 3 & $\begin{array}{l}\text { Algumas pesquisas, entre elas a de Oliveira e Belchior } \\
\text { (2009), indicam que a distinção entre os lugares de homens e } \\
\text { de mulheres no mundo do trabalho não tende a desaparecer } \\
\text { no ramo da informática. É possível que tal distinção também } \\
\text { se aplique aos docentes dos Centros de Ensino Médio do } \\
\text { DF, portanto um dado relevante para uma análise sobre } \\
\text { apropriação didática que está, entre outras, alicerçada no } \\
\text { conhecimento sobre informática e sua aplicação na rotina } \\
\text { pedagógica. No entanto, a única afirmação neste sentido que } \\
\text { podemos fazer é que somente homens se voluntariaram para } \\
\text { participar da pesquisa na etapa das entrevistas. }\end{array}$ \\
\hline Questão 4 & $\begin{array}{l}\text { Conhecer a faixa etária do(a) docente torna-se imprescindível } \\
\text { tendo em vista seu posicionamento sobre as tecnologias, a } \\
\text { utilização de recursos midiáticos disponíveis em dispositivos } \\
\text { midiáticos e própria velocidade da mudança proporcionada } \\
\text { pela internet. }\end{array}$ \\
\hline Questão 5 & $\begin{array}{l}\text { O tempo de exercício no magistério revela o posicionamento } \\
\text { do(a) professor(a) com relação às TDICE. Possivelmente, } \\
\text { revelam-se seus motivos para aceitar ou rejeitar determinada } \\
\text { proposta de inclusão digital, pois ele(a) pode aceitar ou } \\
\text { recusar a inserção de tecnologias no cotidiano escolar, } \\
\text { devido a outras experiências com ferramentas similares. }\end{array}$ \\
\hline Questão 6 & $\begin{array}{l}\text { Estabelece relação com a questão } 2 \text { do questionário geral, } \\
\text { revelando a relação entre formação inicial e exercício do } \\
\text { magistério, perpassado pelas tecnologias digitais. }\end{array}$ \\
\hline Questão 7 & $\begin{array}{l}\text { Procurou aprofundamento nas questões sobre formação para } \\
\text { uso da TDICE, desta vez abordando cursos para além da } \\
\text { licenciatura específica para atuação no magistério. }\end{array}$ \\
\hline Questão 8 & $\begin{array}{l}\text { Esta questão indagou sobre o uso de dispositivos similares } \\
\text { ao tablet educacional, o que pode favorecer a apropriação } \\
\text { didática por sobreposição de usos, do pessoal para o } \\
\text { profissional. }\end{array}$ \\
\hline \multicolumn{2}{|c|}{ Questionário Nível 1: para todos(as) os(as) colaboradores(as) da pesquisa } \\
\hline Questão 1 & $\begin{array}{l}\text { Aprofunda a questão } 8 \text { do questionário geral, sendo mais } \\
\text { específica quanto ao dispositivo/aparelho utilizado fora do }\end{array}$ \\
\hline
\end{tabular}




\begin{tabular}{|c|c|}
\hline & $\begin{array}{l}\text { ambiente escolar. É possível que um(a) professor(a) utilize } \\
\text { uma ferramenta similar (tablet de outra marca ou modelo, por } \\
\text { exemplo) para uso ordinário, mas se recuse a utilizar o tablet } \\
\text { educacional devido ao seu caráter institucional. }\end{array}$ \\
\hline Questão 2 & Estabeleceu relação com a aceitação do tablet educacional. \\
\hline Questão 3 & $\begin{array}{l}\text { Procurou conhecer qual(quais) foi(foram) o(s) motivo(s) para } \\
\text { aceitar a ferramenta didática. }\end{array}$ \\
\hline Questão 4 & $\begin{array}{l}\text { Indica a continuidade ou término da participação, bem como } \\
\text { confirma a opção assinalada na questão } 5 \text {. }\end{array}$ \\
\hline \multicolumn{2}{|c|}{ Questionário Nível 2: para os(as) docentes que receberam o tablet educacional } \\
\hline Questão 1 & $\begin{array}{l}\text { Aqui o(a) docente revelou se permaneceu com a posse do } \\
\text { tablet educacional ou se o devolveu. } 10 \text { dias foram } \\
\text { considerados tempo suficiente para que o(a) docente } \\
\text { conhecesse minimamente a ferramenta didática. }\end{array}$ \\
\hline Questão 2 & $\begin{array}{l}\text { Esta questão completa a investigação da questão } 1 \text { do } \\
\text { questionário do nível } 2 \text {, para o posicionamento positivo, } \\
\text { revelando suas impressões sobre o dispositivo. }\end{array}$ \\
\hline Questão 3 & Indica a continuidade ou término da participação. \\
\hline \multicolumn{2}{|c|}{ Questionário Nível 3: para os(as) docentes que permaneceram em posse do tablet educacional } \\
\hline Questão 1 & $\begin{array}{l}\text { Perguntou sobre a participação no curso oferecido pela } \\
\text { EAPE, procurando verificar se este tipo de formação } \\
\text { influenciou o uso do tablet educacional na escola. }\end{array}$ \\
\hline Questão 2 & $\begin{array}{l}\text { É possível que o curso oferecido não tenha suprido a } \\
\text { necessidade do(a) professor(a), levando-o(a) à desistência/ } \\
\text { evasão. Ou que o curso tenha fomentado a inovação didática } \\
\text { e facilitado a introdução do tablet educacional na rotina } \\
\text { pedagógica. }\end{array}$ \\
\hline Questão 3 & $\begin{array}{l}\text { Buscou conhecer experiências vividas pelo(a) docente que } \\
\text { podem ter influenciado a aceitação da ferramenta } \\
\text { pedagógica. }\end{array}$ \\
\hline Questão 4 & $\begin{array}{l}\text { Esta questão tem como finalidade conhecer o tipo de } \\
\text { atividade desenvolvida pelo professor. Posteriormente, este } \\
\text { dado contribuirá para a análise do uso, mau uso ou desuso } \\
\text { do tablet educacional, conforme premissa do programa. }\end{array}$ \\
\hline
\end{tabular}




\begin{tabular}{|c|l|}
\hline Questão 5 & $\begin{array}{l}\text { Objetiva saber o posicionamento do(a) docente sobre o uso } \\
\text { pedagógica do tablet educacional, se ele(a) vê possibilidade } \\
\text { de utilização do mesmo em sua rotina. }\end{array}$ \\
\hline Questão 6 & $\begin{array}{l}\text { Questão que completa o sentido da anterior, confirmando e } \\
\text { aprofundando a discussão sobre a inserção e o uso do tablet } \\
\text { educacional. }\end{array}$ \\
\hline Questão 7 & $\begin{array}{l}\text { Com esta questão, cruzada a questão 6 do questionário do } \\
\text { nível 3, contribui para que possamos estabelecer a diferença } \\
\text { entre o uso ordinário (apropriação ordinária) e o uso didático } \\
\text { (apropriação didática). }\end{array}$ \\
\hline Questão 8 & $\begin{array}{l}\text { Aqui o(a) docente, que já utiliza o tablet educacional, fornece } \\
\text { sua percepção sobre a importância do uso didático da } \\
\text { ferramenta em sua rotina, afirmando se houve ou não algum } \\
\text { tipo de melhoria. }\end{array}$ \\
\hline Questão 9 & $\begin{array}{l}\text { Questão que aprofunda a anterior, sendo mais específica no } \\
\text { tipo de melhoria percebida após adoção do tablet } \\
\text { educacional. }\end{array}$ \\
\hline Questão 10 & $\begin{array}{l}\text { Nesta questão o(a) professor registra os impeditivos para o } \\
\text { uso do dispositivo na rotina pedagógica. Algumas pesquisas, } \\
\text { já apontadas neste trabalho, revelam dificuldades diversas } \\
\text { para o uso do tablet como ferramenta pedagógica, apesar de } \\
\text { os(as) docentes reconhecerem sua importância. }\end{array}$ \\
\hline Questão 11 \\
$\begin{array}{l}\text { Como sabemos, o clima organizacional é muito importante } \\
\text { para o sucesso de qualquer ação pedagógica. Portanto, } \\
\text { incentivos institucionais e oportunidades para a troca de } \\
\text { experiências são fundamentais para que o professorado } \\
\text { amplie as possibilidades de reformulação de seu cotidiano. E } \\
\text { tudo isso depende do ambiente favorável à aprendizagem e, } \\
\text { consequentemente, ao uso das TDICE. }\end{array}$ \\
\hline $\begin{array}{l}\text { Espaço onde o(a) docente registrou sua vontade de } \\
\text { aprofundar sua participação nesta pesquisa, pois se } \\
\text { voluntaria para a etapa das entrevistas individuais } \\
\text { semiestruturadas. }\end{array}$ \\
\hline antán
\end{tabular}

Passaremos agora para a discussão da entrevista semiestruturada que, como dito anteriormente, dará ênfase à caracterização dos usos, mau usos e desusos pedagógicos do tablet educacional. 


\subsection{2}

\section{A entrevista semiestruturada}

Conforme Stake (2012, p. 81), a entrevista é a via principal para as realidades múltiplas e raramente avança como um inquérito. Posto isto, acreditamos que a entrevista, realizada com os colaboradores de pesquisa no nível 3, possa completar o sentido do questionário, ampliando as possibilidades de análise.

Para Szymanski (2008, p. 30), a entrevista deve ser estruturada observandose os seguintes critérios:

a) consideração dos objetivos de pesquisa;

b) a amplitude da questão, de forma a permitir o desvelamento de informações pertinentes ao tema que se estuda;

c) o cuidado de evitar indução de respostas;

d) a escolha dos termos da pergunta, que deverão fazer parte do universo linguístico do participante;

e) a escolha do termo interrogativo. Ainda para esta autora, o emprego do termo "como" induz a uma narrativa, a uma experiência, tornando-se o preferido para iniciarmos esta etapa da pesquisa.

Neste trabalho, optamos por entrevistas individuais semiestruturadas, tendo como ponto de partida a indagação "Como você utiliza o tablet educacional nas atividades pedagógicas cotidianas?" Acreditamos que a resposta a essa pergunta desencadeará uma série de outras perguntas de investigação que fornecerão partes imprescindíveis para a compreensão do caso.

Rosa e Arnoldi (2008, p. 14) nos alertam para as análises iniciais ao realizar a opção por entrevistas, entre elas, se o problema de pesquisa será solucionado através dessa técnica, se o entrevistador tem conhecimento sobre o tema, se está física e psiquicamente preparado para tal tarefa, tendo em vista as possíveis reviravoltas da técnica, se está capacitado para analisar e codificar os dados obtidos e se a seleção de colaboradores foi a adequada. Acreditamos que temos os requisitos para a realização da técnica, tendo em vista o estudo feito pelo investigador antes da seleção do local de pesquisa e também a experiência adquirida pelo exercício do magistério em várias modalidades e níveis. 
O referencial teórico também é um filtro através do qual o pesquisador enxerga, com exatidão, a realidade, sugerindo perguntas e indicando possibilidades viáveis de prosseguimento da investigação (ROSA E ARNOLDI, 2008). Uma das preocupações existentes, devido à natureza mutante das TDICE, é a de situar a macrossituação social em que a entrevista será realizada para que o discurso seja viabilizado a contento.

Neste trabalho, como a entrevista semiestruturada será realizada somente com os colaboradores de pesquisa que chegarem ao nível 3 (receberam, ficaram com e utilizam o tablet educacional) e após prévia análise do questionário, a pergunta desencadeadora buscará iniciar um diálogo franco e aberto entre o pesquisador e os colaboradores, a fim de nos aprofundarmos nas práticas cotidianas de uso do tablet educacional. Assim, nos voltaremos para os objetivos específicos, conforme roteiro abaixo:

\begin{tabular}{|c|c|}
\hline $\begin{array}{l}\text { Pergunta desencadeadora } \\
\text { Como você utiliza o tablet educacional } r\end{array}$ & s atividades pedagógicas cotidianas? \\
\hline PROSSEGUIMENTO & OBJETIVO ABORDADO \\
\hline $\begin{array}{l}\text { - Quais eram suas expectativas } \\
\text { quando foi receber o tablet } \\
\text { educacional? }\end{array}$ & - Conhecer os motivos que levaram \\
\hline $\begin{array}{l}\text { - Como o sr.(a) imaginava utilizar o } \\
\text { tablet na rotina escolar } \\
\text { (planejamento e sala de aula)? }\end{array}$ & educacional. \\
\hline $\begin{array}{l}\text { - Você acredita ser importante o } \\
\text { uso dessa ferramenta na rotina } \\
\text { escolar? }\end{array}$ & - Verificar se houve mudança na \\
\hline $\begin{array}{l}\text { - O que mudou em sua prática } \\
\text { pedagógica depois que você } \\
\text { começou a usar o tablet? }\end{array}$ & tablet educacional. \\
\hline $\begin{array}{l}\text { - Você conhece as diretrizes para } \\
\text { uso pedagógico do tablet } \\
\text { educacional? }\end{array}$ & $\begin{array}{l}\text { - Caracterizar o uso, o mau uso e o } \\
\text { desuso pedaaóaico do tablet }\end{array}$ \\
\hline $\begin{array}{l}\text { - Em que momentos o tablet é } \\
\text { utilizado? No planejamento da }\end{array}$ & \\
\hline
\end{tabular}


aula, na seleção de material/ conteúdo? $\quad \mathrm{Na}$ comunicação institucional? $\mathrm{Na}$ ampliação de espaços de ensino, como blog, grupos de estudo no Facebook?

Caso as questões iniciais não estivessem funcionando e se tornassem evidentes que novos temas surgiram, o plano seria alterado. A este processo Parlett e Hamilton (apud STAKE, 2012, p. 24) chamam de focalização progressiva. 
INFORMAÇÕES OBTIDAS PELO QUESTIONÁRIO ON-LINE E NAS ENTREVISTAS SEMIESTRUTURADAS

Neste capítulo apresentaremos as informações obtidas através do questionário on-line, apresentado no capítulo 4.5.1 desta dissertação, preenchido por 32 (trinta e dois) colaboradores, e das entrevistas semiestruturadas realizadas com 4 (quatro) desses sujeitos. Tais dados serão expostos na sequência de obtenção, não havendo, nesse momento, preocupação com a sua concatenação.

\section{1}

\section{Campo de pesquisa: chegando e conhecendo o terreno}

A primeira etapa consistiu em solicitar à EAPE autorização de acesso aos dados do curso intitulado Tablet Educacional como Ferramenta Pedagógica, formação que envolveu de forma compulsória ${ }^{22}$ os(as) docentes regentes do Ensino Médio. Foi necessário preencher requerimento e anexar carta de apresentação da instituição de origem (FE UnB). Também foi preciso aguardar 23 (vinte e três) dias para obter o resultado.

Com autorização em mão, a Gerência de Educação a Distância da EAPE nos forneceu atas das turmas, relatório final de curso, termo de permissão de uso e guarda do tablet educacional e e-mail dos cursistas (sem identificação dos participantes). De posse desse material, iniciamos a análise documental procurando indícios da apropriação didática (tal análise será explanada posteriormente).

Selecionamos aleatoriamente 15 (quinze) docentes para testarmos 0 instrumento de coleta de dados (questionário on-line), construído tendo como base os objetivos da pesquisa e moldado pela análise documental. Cinco docentes responderam e foram indagados sobre a clareza do instrumento, tempo necessário para preenchimento e pertinência das perguntas. Após alguns ajustes, um e-mail

${ }^{22} \mathrm{O}(\mathrm{A})$ docente, ao aceitar/receber o tablet educacional, se comprometia a participar do curso de formação para uso pedagógico e oficinas de formação continuada para uso da tecnologia, conforme está registrado no Termo de Permissão de Uso e Guarda (anexo 01). A expressão "formação compulsória" foi utilizada no Relatório Final de Curso da EAPE, no dia 27 de março de 2014. 
convite para participação na pesquisa foi enviado para 1.372 (mil trezentos e setenta e dois) docentes, todos(as) inscritos(as) no curso para uso do tablet educacional como ferramenta educacional, consequentemente, todos(as) haviam aceitado/recusado o tablet educacional.

Deste total, 1.028 (mil e vinte e oito) foram considerados enviados e válidos. O e-mail contextualizava a pesquisa, explanava seus objetivos, exibia informações sobre a instituição promotora do trabalho, pesquisador e orientador, bem como fornecia um link que conduzia ao questionário. Destes, 37 (trinta e sete) responderam ao nosso chamado, mas apenas 32 (trinta e dois) aceitaram participar da pesquisa (ciência e aceite on-line do Termo de Consentimento Livre e Esclarecido - TCLE), ou seja, apenas estes responderam nosso questionário.

\section{2}

Informações oferecidas pelo questionário on-line e considerações iniciais

Levando em consideração apenas os e-mails enviados e válidos, obtivemos o retorno de $3,11 \%$ do público-alvo de nosso trabalho, o que pode parecer pouco, comparado ao universo possível, mas que nos forneceu muitas informações para análise. Tais dados serão expostos e brevemente discutidos em seguida. Ressaltamos que essas informações voltarão ao foco da análise em capítulo distinto.

Quanto à Coordenação Regional de Ensino (CRE) de origem, apresentamos a tabela abaixo, com destaque para as que tivemos colaboradores de pesquisa:

Tabela 1: CRE e colaboradores de pesquisa

\begin{tabular}{|l|c|c|}
\hline \multicolumn{1}{|c|}{ CRE } & $\begin{array}{c}\text { QUANTIDADE DE } \\
\text { COLABORADORES }\end{array}$ & $\%$ \\
\hline Brazlândia & $\mathbf{0}$ & $0 \%$ \\
\hline Ceilândia & $\mathbf{1 7}$ & $53.1 \%$ \\
\hline Gama & $\mathbf{4}$ & $12.5 \%$ \\
\hline Guará & $\mathbf{0}$ & $0 \%$ \\
\hline Núcleo Bandeirante & $\mathbf{0}$ & $0 \%$ \\
\hline Paranoá & $\mathbf{0}$ & $0 \%$ \\
\hline Planaltina & $\mathbf{0}$ & $0 \%$ \\
\hline Plano Piloto/Cruzeiro & $\mathbf{0}$ & $0 \%$ \\
\hline Recanto das Emas & $\mathbf{1}$ & $3.1 \%$ \\
\hline Samambaia & $\mathbf{2}$ & $6.3 \%$ \\
\hline
\end{tabular}




\begin{tabular}{|l|c|c|}
\hline Santa Maria & $\mathbf{1}$ & $3.1 \%$ \\
\hline São Sebastião & $\mathbf{1}$ & $3.1 \%$ \\
\hline Sobradinho & $\mathbf{0}$ & $0 \%$ \\
\hline Taguatinga & $\mathbf{6}$ & $18.8 \%$ \\
\hline Brazlândia & $\mathbf{0}$ & $0 \%$ \\
\hline
\end{tabular}

Fonte: Pesquisa em discussão.

Nota-se uma participação predominante das CRE do lado sul do DF, apesar de termos docentes que aceitaram/recusaram o tablet educacional em todas as CRE do DF, conforme constatamos nas atas das turmas. Não foi possível verificar, nesta pesquisa, os motivos de tal situação.

A licenciatura (formação inicial para exercício do magistério) dos(as) participantes está exposta na tabela abaixo, com destaque para as que tivemos colaboradores de pesquisa:

Tabela 2: Licenciatura (formação inicial para exercício do magistério)

\begin{tabular}{|l|c|c|}
\hline \multicolumn{1}{|c|}{ LICENCIATURA } & $\begin{array}{c}\text { QUANTIDADE DE } \\
\text { COLABRADORES }\end{array}$ & $\%$ \\
\hline Pedagogia & $\mathbf{1}$ & $3.1 \%$ \\
\hline História & $\mathbf{8}$ & $25 \%$ \\
\hline Química & $\mathbf{0}$ & $0 \%$ \\
\hline LEM Inglês & $\mathbf{2}$ & $6.3 \%$ \\
\hline Filosofia & $\mathbf{0}$ & $0 \%$ \\
\hline Língua Portuguesa & $\mathbf{5}$ & $15.6 \%$ \\
\hline Geografia & $\mathbf{4}$ & $12.5 \%$ \\
\hline Biologia & $\mathbf{5}$ & $15.6 \%$ \\
\hline LEM Espanhol & $\mathbf{0}$ & $0 \%$ \\
\hline Matemática & $\mathbf{5}$ & $15.6 \%$ \\
\hline Física & $\mathbf{1}$ & $3.1 \%$ \\
\hline Educação Física & $\mathbf{1}$ & $3.1 \%$ \\
\hline Sociologia & $\mathbf{0}$ & $0 \%$ \\
\hline Arte & $\mathbf{0}$ & $0 \%$ \\
\hline Outros & $\mathbf{0}$ & $0 \%$ \\
\hline
\end{tabular}

Fonte: Pesquisa em discussão.

Conforme o Currículo em Movimento da Educação Básica do DF - Ensino Médio $^{23}$ (GDF/ SEEDF, 2013), as áreas do conhecimento podem ser organizadas da

${ }^{23}$ Disponível em: <https://issuu.com/sedf/docs/5-ensino-medio>. Acesso em: 14 jan. 2016, às 20h32min. 
seguinte maneira: Linguagens (Língua Portuguesa, Língua Estrangeira Moderna Inglês, Língua Estrangeira Moderna Espanhol, Educação Física e Arte); Ciências Humanas (História, Geografia, Sociologia e Filosofia); Ciências da Natureza (Biologia, Física e Química); e Matemática.

Assim, podemos constatar que 37,50\% dos CQ (Colaboradores de Pesquisa Questionário) são da área de Ciências Humanas; 25\% são da área de Linguagens; 18,75\% são da área de Ciências da Natureza; 15,63\% são da área de Matemática; e que $3,12 \%$ cursaram Pedagogia. Tal dado nos permite dizer que as áreas voltadas com maior ênfase para a comunicação e expressão manifestaram maior interesse em participar.

O quesito gênero expõe que $53,1 \%$ são docentes masculinos e $46,9 \%$ são docentes femininos. Não há, até o momento, indícios que nos levem a afirmar que um gênero predomina sobre o outro no que se refere a aceitar/recusar o tablet ou utilizá-lo como ferramenta didática na rotina escolar. Uma investigação com cruzamento de itens poderá indicar uma forma diferente de apropriação didática do tablet educacional.

A faixa etária dos colaboradores de pesquisa (CQ) é de 29 a 49 anos, com predominância entre 33 e 40 anos, ou seja, sujeitos adultos, com boa experiência de vida, que são considerados imigrantes digitais (PRENSKY, 2001), pois viram as tecnologias digitais se desenvolverem, se consolidarem e agora precisam passar por um processo de inclusão, mesmo que alguns sejam contrários a este processo, tendo em vista a tecnologia ubíqua (WEISER, 1991).

Quanto ao tempo de exercício do magistério, podemos registrar que os $\mathrm{CQ}$ têm entre 4 e 22 anos de experiência profissional docente, tendo duas concentrações distintas, uma no início da vida profissional (17 docentes) e outra no meio da carreira (14 docentes), com destaque aos profissionais que iniciaram sua atividade em plena expansão da tecnologia digital nas escolas, marcada, por exemplo, pela criação do Projeto Um Computador por Aluno, em 2007. Projeto que foi, ainda em seu pré-piloto, objeto de investigação acadêmica (dissertação) de Falcão (2012).

Um dado revelado pelo questionário e que requer atenção especial é o fato de que $90,6 \%$ dos(das) docentes participantes da pesquisa não tiveram nenhuma disciplina que discutisse a didática voltada para o uso das tecnologias digitais em seus cursos de licenciatura. Posto isto, podemos dizer que a formação primeira para 
o exercício profissional desconsiderou a existência das tecnologias digitais como ferramentas didáticas. Lembramos que Lacerda Santos (2011) destaca como prioridade a importância da educação mediada por tecnologias digitais na formação de professores.

Quando perguntados sobre a participação em cursos para uso da TDICE, $100 \%$ dos(das) colaboradores(as) da pesquisa responderam que nunca haviam participado. Se ao(à) docente não foi oportunizada a formação profissional inicial para uso da TDICE em sala de aula, é de se esperar que ele procure uma formação continuada que Ihe possibilite explorar as possibilidades didáticas dos dispositivos tecnológicos e suas linguagens, pois, segundo Perrenoud (2000, p. 158), o(a) docente precisa estabelecer seu próprio balanço de competências e seu programa pessoal de formação contínua. No entanto, o grupo pesquisado permanece sem tal formação, item importante para a apropriação didática.

$59,4 \%$ dos(das) colaboradores(as) afirmaram já terem operado algum tipo de dispositivo móvel com características similares as do tablet educacional. Dessa forma, se o(a) docente tem conhecimento prévio do dispositivo, as chances deste se tornar uma ferramenta didática aumentam, pois a familiarização pode contribuir para a autonomia e confiança na utilização.

Quando analisamos o uso de dispositivos midiáticos, aqui entendidos como aparelhos de acesso à informação e à comunicação, fora da escola, o(a) docente colaborador(a) da pesquisa utiliza com mais frequência (frequentemente ou sempre) o personal computer (PC), e isso foi registrado por $81,3 \%$ dos participantes. Vem logo em seguida o notebook com $71,9 \%$. E em terceiro lugar, o smartphone com $62,5 \%$. Números superiores ao uso do tablet fora da escola, sendo que $100 \%$ responderam que o utilizam raramente, ou nunca.

Dos 32 (trinta e dois) CQ, 26 (vinte e seis) aceitaram receber o tablet educacional, o que corresponde a $81,3 \%$. Seis CQ não aceitaram receber. Os motivos da aceitação ou da recusa serão expostos em seguida.

Quando perguntados sobre os motivos que incentivaram a aceitação ou a recusa do tablet educacional, as respostas foram conforme tabela abaixo:

Tabela 3: Motivos para aceitação ou recusa do tablet educacional

CQ1 $\quad$ Em busca de agilidade e pesquisas durante as aulas e como ferramenta de trabalho.

CQ2 Atualização, a novidade, a possibilidade de interagir melhor com os alunos. 


\begin{tabular}{|c|c|}
\hline CQ3 & Aceitei pela novidade. Acreditei que teria uma acompanhamento e que daria certo. \\
\hline CQ4 & Não tive escolha! \\
\hline CQ5 & $\begin{array}{l}\text { Pela novidade. Pensei que seria uma coisa boa, mas percebi que é muito diferente do } \\
\text { imaginei. Com pouco uso ele ficou lento e não tinha mais memória. } O \text { vídeos travavam } \\
\text { muito. }\end{array}$ \\
\hline CQ6 & A utilização de tecnologias sempre é bem-vinda. \\
\hline CQ7 & $\begin{array}{l}\text { Aceitei devido a proposta. Imaginei que fosse acontecer um curso consistente sobre } 0 \\
\text { uso do tablet. }\end{array}$ \\
\hline CQ8 & $\begin{array}{l}\text { Era novidade e imaginava uma perspectiva de trabalho interessante. Pensei que fosse } \\
\text { ser inovador. }\end{array}$ \\
\hline CQ9 & $\begin{array}{l}\text { Pela novidade. Eu não sabia qual seria o modelo e fui empolgada para pegar. Queria } \\
\text { ver meus e-mails, me comunicar melhor com os estudantes, mas depois não } \\
\text { funcionou como pensei. }\end{array}$ \\
\hline CQ10 & $\begin{array}{l}\text { Por ser uma coisa nova na rede pública. Imaginei que fosse algo mais sério, que } \\
\text { tivesse futuro. Mas no DF a política acaba com tudo, principalmente com coisas boas. }\end{array}$ \\
\hline CQ11 & Não me foi oferecido. \\
\hline CQ12 & $\begin{array}{l}\text { Pela proposta de uso. Os alunos já mexem com essas coisas e nós professores } \\
\text { precisamos interagir com eles. E o tablet se apresentou com uma boa alternativa. } \\
\text { Além de ser fácil de carregar e trabalhar. Minha filha tinha um e não largava. }\end{array}$ \\
\hline CQ13 & $\begin{array}{l}\text { Toda tecnologia na escola pode ajudar muito. O tablet tem um potencial grande de } \\
\text { comunicação. Imaginei todo um trabalho com ele. Grupos de discussão, complemento } \\
\text { de conteúdo, vídeos, imagens, até apresentações em 3D. Por isso aceitei o tablet. }\end{array}$ \\
\hline CQ14 & $\begin{array}{l}\text { O grupo da escola tinha combinado que receberia e que utilizaríamos. Pensei em } \\
\text { blogs, redações, vídeoaulas, ou seja, pensei que um novo espaço de ensino e } \\
\text { aprendizagem poderia ser criado. Então foi uma combinação, nosso grupo e as } \\
\text { possibilidades didáticas. }\end{array}$ \\
\hline CQ15 & $\begin{array}{l}\text { Eu acreditei que pudesse contribuir para o ensino. Era uma novidade e os alunos } \\
\text { gostam de tecnologia. }\end{array}$ \\
\hline CQ16 & $\begin{array}{l}\text { Combinamos na escola de pegarmos e utilizarmos nas aulas. Chegamos até a } \\
\text { planejar algumas atividades. Era muito promissor. }\end{array}$ \\
\hline CQ17 & $\begin{array}{l}\text { Os alunos gostam muito de tecnologia, então pensei em melhorar o relacionamento } \\
\text { com eles e com o conteúdo. Imaginei uma interação melhor com o tablet. }\end{array}$ \\
\hline CQ18 & $\begin{array}{l}\text { Era mais uma opção de trabalho em sala. Imaginei que haveria um apoio, um suporte } \\
\text { para usar o tablet. }\end{array}$ \\
\hline CQ19 & $\begin{array}{l}\text { Sempre trabalhei com algum aparelho em sala e o tablet poderia ser mais um a ajudar } \\
\text { nas aulas. Os alunos precisam de outros recursos, principalmente um como esse que } \\
\text { muitos já conhecem. }\end{array}$ \\
\hline CQ20 & $\begin{array}{l}\text { Era nova na secretaria e procurava formas diferentes e mais chamativas para lecionar. } \\
\text { Só o livro não ajuda muito para os dias de hoje. }\end{array}$ \\
\hline CQ21 & $\begin{array}{l}\text { Imaginei que pudesse ser uma forma mais abrangente de desenvolver a leitura e a } \\
\text { escrita, principalmente a comunicação e a expressão. Poderia passar vídeos de obras } \\
\text { e explorar outras linguagens. }\end{array}$ \\
\hline CQ22 & $\begin{array}{l}\text { Os aluno de hoje só querem saber de celular, então o governo oferece algo parecido... } \\
\text { achei melhor aceitar e acreditar que pudesse melhorar o interesse deles em estudar. } \\
\text { Pensei nas possibilidades de trabalho (vídeos, leituras, pesquisa etc.). É o novo. }\end{array}$ \\
\hline CQ23 & Eu usava muito cartaz e projeções em sala, então achei que com o tablet pudesse \\
\hline
\end{tabular}




\begin{tabular}{|l|l|}
\hline CQ24 & $\begin{array}{l}\text { ficar mais fácil ensinar. } \\
\text { possibilidade de envolver mais essas adolescente com o conteúdo. E também queria } \\
\text { conhecer e aprender a trabalhar com esses aparelhos. Não tive formação para isso. }\end{array}$ \\
\hline CQ25 & $\begin{array}{l}\text { A proposta era inovadora, então acreditei que fosse dar certo. Nunca tinha trabalhado } \\
\text { com um tablet antes e queria conhecer. }\end{array}$ \\
\hline CQ26 & Não queria participar de mais um circo do governo. \\
\hline CQ27 & Era a novidade. Todos comentavam e faziam planos. Eu acreditei. \\
\hline CQ28 & $\begin{array}{l}\text { Era nova na secretaria e não entendia como as coisas funcionavam. E os colegas não } \\
\text { viam com bons olhos. }\end{array}$ \\
\hline CQ29 & $\begin{array}{l}\text { Os alunos no Ensino Médio só demonstram interesse pela aula se o professor estiver } \\
\text { sintonizado com eles. E uma forma de conseguir isso é utilizando os aparelhos que } \\
\text { eles utilizam e tendo uma linguagem próxima a deles. Então, imaginei que o tablet } \\
\text { pudesse ajudar nesse trabalho. }\end{array}$ \\
\hline CQ30 & $\begin{array}{l}\text { Para ser sincero, acabei aceitando por ser uma novidade. Não pensei em muita coisa } \\
\text { além disso. Nunca tinha usado um antes e queria experimentar. }\end{array}$ \\
\hline CQ31 & $\begin{array}{l}\text { Não podia aceitar uma ilusão. Com tanto a se fazer nas escolas e o governo gastando } \\
\text { com tablet, uma vergonha. Os banheiros não tem porta, o teto fica caindo, ou seja, } \\
\text { tem coisa mais importante para gastar nosso dinheiro. }\end{array}$ \\
\hline CQ32 & $\begin{array}{l}\text { Era nova de secretaria e não tinha muito jeito para isso. Não tinha estudado nada } \\
\text { sobre informática na escola. Não me senti preparada. }\end{array}$ \\
\hline
\end{tabular}

Fonte: Pesquisa em discussão.

$\square$ Aceitaram $\square$ Recusaram

$\mathrm{Na}$ questão que indagou se o(a) docente havia ficado com o tablet por um período igual ou superior a 10 (dez) dias, 27 (vinte e sete) CQ afirmaram que sim, porém o CQ04 registrou que aceitou o tablet por não ter tido escolha. No entanto, ele não ficou com o tablet, ele apenas preferiu permanecer participando da pesquisa e a única forma de continuar, devido à programação do questionário on-line, era marcando a opção "sim" para a pergunta encruzilhada.

Para os(as) docentes que ficaram com o aparelho, conforme solicitou a questão anterior, a impressão foi a apresentada na tabela abaixo:

Tabela 4: Impressões sobre o tablet educacional

\begin{tabular}{|c|l|}
\hline CQ1 & Aparelho ultrapassado, programa antigo e em desuso. \\
\hline CQ2 & Lento, pouca memória, muito frágil e com wi-fi ruim. \\
\hline CQ3 & Não gostei. Lento e não cabe nada. Até para passar um vídeo é complicado. \\
\hline CQ4 & $\begin{array}{l}\text { Considero que quando o aparelho foi disponibilizado para os professores ele já estava } \\
\text { obsoleto. }\end{array}$ \\
\hline CQ5 & $\begin{array}{l}\text { Ficou lento com pouco uso e a memória é insuficiente. Mas ainda foi possível usar por } \\
\text { um período. As atualizações impediram que fosse utilizado mais vezes. }\end{array}$ \\
\hline CQ6 & Não o utilizei por ter dado defeito. \\
\hline
\end{tabular}




\begin{tabular}{|c|c|}
\hline CQ7 & $\begin{array}{l}\text { No início pareceu muito bom. mas depois ficou lento e travando. Não consegui mais } \\
\text { usar. Tinha de resetar com frequência. A internet ficava lenta nele. }\end{array}$ \\
\hline CQ8 & $\begin{array}{l}\text { O tablet era frágil, lento e com tela ruim. A memória era pequena. Não vi praticidade } \\
\text { no uso. Travava demais. Quando ia utilizar em sala tinha problemas. Deixei de usar, } \\
\text { pois perdia muito tempo tentando consertar. }\end{array}$ \\
\hline CQ9 & Tela ruim. Tinha de apertar forte para clicar em algo. E muito lento. Travava muito. \\
\hline CQ10 & $\begin{array}{l}\text { Gostei no início. Pequeno, leve, a tela sensível, mas depois de alguns dias ficou lento } \\
\text { e não tinha mais espaço na memória. Tive de abandonar por ficar travando muito. }\end{array}$ \\
\hline CQ12 & $\begin{array}{l}\text { Gostei, mas não tive tempo de aprender a trabalhar nele. Alguns colegas diziam que } \\
\text { era ruim, mas nem consegui perceber, pois não sabia mexer. Foi erro meu, não me } \\
\text { preparei para usar. }\end{array}$ \\
\hline CQ13 & $\begin{array}{l}\text { Logo ficou sem uso. Ficou lento e de difícil operação. Memória pequena e } \\
\text { processamento limitado demais. No segundo uso em sala, com vídeo, ele travou. } \\
\text { Tentei novamente e travou. Conversei com os colegas para tentar melhor o } \\
\text { desempenho, mas não funcionou. Um mês depois parei de utilizar. }\end{array}$ \\
\hline CQ14 & $\begin{array}{l}\text { Não houve organização suficiente na escola. Não houve o suporte esperado. A } \\
\text { internet não funcionou nos tablet. Depois não conseguimos construir um projeto que } \\
\text { unisse as disciplinas e foi se perdendo no tempo. Hoje ninguém fala mais. }\end{array}$ \\
\hline CQ15 & $\begin{array}{l}\text { No começo eu gostei, depois, como eu não sabia muito trabalhar com ele, fui deixando } \\
\text { de lado. Ele parece bom, mas utilizei pouco. }\end{array}$ \\
\hline CQ16 & $\begin{array}{l}\text { Sem aplicativos ele é muito bom, mas você precisa instalar alguns aplicativos. É a } \\
\text { partir desse momento que fica complicado. Ele fica lento e travando demais. Até } \\
\text { vídeos fica lento. A conexão com internet é muito ruim demora muito. Sem falar no } \\
\text { espaço para gravar, é pouco demais. Não gostei. Logo tivemos que abandonar. } \\
\text { Alguns colegas que tinham outros modelos de tablets continuaram a usar. Quem não } \\
\text { tinha parou. }\end{array}$ \\
\hline CQ17 & $\begin{array}{l}\text { Eu nunca tinha trabalhado com um tablet, achei fácil, mas não consegui avançar no } \\
\text { trabalho. Alguns aplicativos que coloquei nele não funcionaram direito e a internet era } \\
\text { sempre lenta, tanto na escola quanto em casa. Logo me cansava e trocava pelo } \\
\text { computador normal. }\end{array}$ \\
\hline CQ18 & $\begin{array}{l}\text { Bem... no início fiquei encantada com ele. Nunca tinha tido um tablet e gostei de } \\
\text { mexer nele. Mas depois ficou lento e travava toda hora. No fim deixei de usar e } \\
\text { esqueci no armário. }\end{array}$ \\
\hline CQ19 & $\begin{array}{l}\text { Gostei. O problema é que não tem como ligar no datashow. Eu até indicava o vídeo, } \\
\text { passava o endereço, mas seria melhor se fosse direto para a TV. Mas ajuda muito na } \\
\text { pesquisa da expressões idiomáticas e na compreensão dos termos. Ficou lento } \\
\text { demais, mas como eu só usava com vídeo, eu resetava e voltava a funcionar. }\end{array}$ \\
\hline CQ20 & $\begin{array}{l}\text { Leve e fácil de usar. Um pouco pequeno para mostrar os vídeos e infográficos. Tentei } \\
\text { ligar no projetor, mas não funcionou. Então mostrava para os alunos. Depois percebi } \\
\text { que não servia dessa forma. }\end{array}$ \\
\hline CQ21 & $\begin{array}{l}\text { Gostei. Funcionou bem. Não percebi nenhum problema. Mas a Internet da escola } \\
\text { falhava demais e isso dificultou o trabalho. Depois comecei a trabalhar com o } \\
\text { smartphone, afinal, praticamente cada aluno tinha um. }\end{array}$ \\
\hline CQ22 & $\begin{array}{l}\text { É pequeno e leve. Tinha imaginado algo um pouco maior. Não é tão rápido e tem } \\
\text { pouca espaço para gravar. A Internet não funcionou tão bem como imaginei, nem na } \\
\text { escola nem em casa. Não consegui executar as atividades que pensei que pudesse. }\end{array}$ \\
\hline
\end{tabular}




\begin{tabular}{|c|l|}
\hline CQ23 & $\begin{array}{l}\text { Acredito que o modelo não foi bem escolhido. } \\
\text { poderia usar. Poderia até ser bom, mas logo deixei pra lá. }\end{array}$ \\
\hline CQ24 & $\begin{array}{l}\text { Não gostei. Ainda na fila para retirar, ouvi comentários de que não tinha como ligar no } \\
\text { datashow. Eu queria essa possibilidade. Quando peguei o meu, percebi que funciona } \\
\text { bem, era rápido e leve. Depois a internet ficou lenta demais e travou. Liguei para a } \\
\text { assistência, mas não ficou bom. Deixei de usar. }\end{array}$ \\
\hline CQ25 & $\begin{array}{l}\text { No início gostei, baixei alguns aplicativos, utilizei em sala, fiz indicações, mas depois } \\
\text { migrei para o computador normal, pois o tablet começou a travar, ficava lento demais. }\end{array}$ \\
\hline CQ27 & $\begin{array}{l}\text { Muito simples, esperava algo que suprisse as necessidades que temos na escola. A } \\
\text { escola não forneceu internet e em casa não ficava rápido. Logo dava memória cheia. } \\
\text { No caso da minha disciplina, demorava demais para acessar aplicativos que } \\
\text { ajudassem a entender os cálculos. }\end{array}$ \\
\hline CQ29 & $\begin{array}{l}\text { O Governo poderia ter gastado um pouco mais e comprado algo melhor. Um projeto } \\
\text { muito bom que não funcionou por conta do aparelho. O tablet é muito ruim, lento e } \\
\text { fraco. Dinheiro jogado fora, ele parece de brinquedo. Foi decepcionante. }\end{array}$ \\
\hline CQ30 & $\begin{array}{l}\text { Ainda bem que não tinha grandes expectativas. Parou de funcionar pouco tempo } \\
\text { depois que comecei a usar. Devolvi para a secretaria. }\end{array}$ \\
\hline
\end{tabular}

Fonte: Pesquisa em discussão

$\square$ Impressão positiva $\square$ Impressão negativa $\square$ Impressão mista

Os $C Q$ registraram 15 (quinze) impressões negativas, 6 (seis) positivas e 6 (seis) mistas. As questões pertinentes ao hardware do tablet foram citadas 21 (vinte e uma) vezes. Software, formação docente e estrutura da escola foram citadas 3 (três) vezes cada. Memória insuficiente e processamento lento foram citados por 8 (oito) e 16 (dezesseis) vezes, respectivamente. O uso didático, questão principal de nossa pesquisa, foi citado por 7 (sete) colaboradores.

Todos(as) os(as) 27 (vinte e sete) CQ ficaram mais de dez dias com o tablet educacional, tempo que acreditamos ser suficiente para o conhecimento básico do dispositivo, tendo em vista a expectativa de posse e uso dos(as) docentes enquanto usuários de uma nova tecnologia ${ }^{24}$.

Porém, apenas 20 (vinte) docentes realizaram a inscrição no curso Tablet Educacional como ferramenta pedagógica. Ressaltamos que, de acordo com o Termo de permissão de uso e guarda (anexo 01), assinado no momento da entrega do tablet, o(a) docente comprometeu-se em participar do referido curso.

Destes 20 (vinte), apenas 6 (seis) concluíram o curso e receberam o certificado de participação e sucesso. 15 (quinze) não concluíram o curso, sendo

\footnotetext{
${ }^{24}$ O termo nova tecnologia foi empregado no sentido de ser algo novo para o sujeito, de se apresentar pela primeira vez.
} 
uma resposta de um colaborador que não realizou a inscrição, mas acreditamos ter marcado a opção por engano.

Quando perguntados se já haviam participado de outros programas de inclusão digital para docentes, 10 (dez) responderam que sim, 17 (dezessete) marcaram a opção não.

Quanto aos usos mais comuns do tablet educacional, os(as) docentes citaram: interação em redes sociais (74\%); pesquisas gerais (busca de informações) (88,9\%); verificação de correio eletrônico (74\%); leitura variada (74\%); e exibição de vídeos $(51,8 \%)$. Nas opções menos marcadas tivemos: preenchimento do diário eletrônico (92,6\%); jogos diversos (100\%); ouvir música (96,3\%); e fotografia $(74 \%)$.

Quando perguntados se consideravam o tablet educacional uma ferramenta pedagógica, $85,2 \%$ responderam que sim. Quantidade que diminuiu quando a questão se relacionou à utilização na rotina pedagógica, pois apenas $55,6 \%$ afirmaram usá-lo em atividades de coordenação pedagógica (planejamento) ou regência de classe.

Voltando-se diretamente para as atividades pedagógicas, aquelas que podem revelar a apropriação didática do dispositivo, os itens mais citados foram: aprofundamento de conteúdo $(70,4 \%)$ e revisão de conteúdos (59,3\%). Divulgação de eventos e fórum de discussão, $7,4 \%$ cada. Ressalva para os que não veem utilização do tablet educacional em sua rotina (25,9\%).

Questionados se perceberam alguma melhoria no exercício profissional, 63\% disseram que não perceberam, com $37 \%$ afirmando que sim.

Quanto à melhoria percebida, os(as) docentes registraram: relação com o conhecimento (29,6\%), relação com os estudantes $(25,9 \%)$, e ensino em sala de aula $(22,2 \%)$, seguidas de rendimento dos estudantes, uso da tecnologia e planejamento do trabalho ( $11,1 \%$ cada).

A pesquisa também se preocupou em conhecer as dificuldades de uso do tablet educacional na escola. Os(As) docentes apontaram como obstáculos ao uso: falta de internet $(81,5 \%)$ e problemas no hardware $(81,5 \%)$ como as principais. Mas também foram citados o pouco ou nenhum incentivo para uso (37\%) e pouco conhecimento da ferramenta $(22,2 \%)$.

Um dado interessante foi que $100 \%$ dos(as) docentes colaboradores da pesquisa afirmaram que o ambiente escolar não foi favorável ao uso do tablet educacional. 


\section{3}

Os colaboradores da pesquisa na etapa das entrevistas semiestruturadas

Na etapa seguinte, contamos novamente com os colaboradores de pesquisa, mas desta vez para a participação em entrevistas semiestruturadas. A inclusão dos colaboradores de pesquisa nesta etapa deu-se por manifestação no questionário eletrônico. Dois docentes deixaram o e-mail para que pudéssemos entrar em contato e acertarmos a participação. Para estes dois perguntamos se outros colegas tinham recebido o tablet e se poderiam participar da pesquisa. Um colaborador indicou dois colegas docentes. O grupo foi fechado com 4 (quatro) CE, sendo três em Santa Maria e um na Ceilândia.

Assim, apresentamos abaixo os colaboradores de pesquisa para entrevista $(\mathrm{CE})$ :

Tabela 5: Apresentação dos colaboradores de pesquisa para entrevista

\begin{tabular}{|c|c|}
\hline CE1: & $\begin{array}{l}34 \text { anos, professor licenciado em Física, concurso efetivo, concursado para o } \\
\text { componente curricular de exercício, programador, } 12 \text { anos de experiência no } \\
\text { magistério, } 3 \text { anos na mesma Unidade de Ensino (UE). Possuí e utiliza com } \\
\text { frequência aparelhos das TDICE (tablet, smartphone; PC e notebook). Não soube } \\
\text { precisar o tempo diário dos aparelhos, mas afirma ser muito tempo, estimativa } \\
\text { acima de } 5 \text { (cinco) horas de uso. }\end{array}$ \\
\hline CE2: & $\begin{array}{l}40 \text { anos, professor licenciado em Matemática, concurso efetivo, concursado para o } \\
\text { componente curricular Atividades (Educação Infantil até o } 5^{\circ} \text { ano), } 18 \text { anos de } \\
\text { experiência no magistério, sendo } 12 \text { anos em Atividades e } 6 \text { anos no ensino de } \\
\text { Matemática (na mesma UE). Possui e utiliza com frequência aparelhos das TDICE } \\
\text { (tablet, smartphone; PC e notebook). Afirma utilizar de forma funcional (somente } \\
\text { para comunicação). Uso principal do smartphone, com certa de } 2 \text { horas (tempo } \\
\text { alternado). }\end{array}$ \\
\hline CE3: & $\begin{array}{l}42 \text { anos, professor licenciado em Biologia, concurso efetivo, concursado para o } \\
\text { componente curricular de exercício, também licenciado em Informática, ex-formador } \\
\text { do Núcleo de Tecnologia Educacional (NTE) de Santa Maria/ DF, } 21 \text { anos de } \\
\text { experiência profissional. Possui e utiliza com frequência aparelhos das TDICE } \\
\text { (tablet, smartphone; PC e notebook). Não soube precisar o tempo diário dos } \\
\text { aparelhos, mas afirma ser muito tempo, estimativa acima de } 4 \text { (quatro) horas de } \\
\text { uso, em especial pelo smartphone. Na época da entrevista ocupava a função de } \\
\text { Coordenador Pedagógico da UE. }\end{array}$ \\
\hline CE4: & $\begin{array}{l}40 \text { anos, professor licenciado em História, concurso efetivo, concursado para o } \\
\text { componente curricular, atualmente em exercício no NTE Ceilândia/ DF, } 16 \text { anos de } \\
\text { experiência profissional. Possui e utiliza com frequência aparelhos das TDICE } \\
\text { (tablet, smartphone; PC e notebook). Por conta de seu exercício atual, utiliza os }\end{array}$ \\
\hline
\end{tabular}


aparelhos da TDICE mais de 8 (oito) horas por dia.

Fonte: Pesquisa em discussão.

As entrevistas foram realizadas nas Unidades de Ensino dos entrevistados, no horário de coordenação pedagógica. Antes da entrevista, a Equipe Gestora da UE recebeu a carta de apresentação do orientador da pesquisa (Prof. Gilberto Lacerda dos Santos) e a autorização da EAPE. O projeto de pesquisa foi apresentado para os interessados e foi feita a solicitação de um espaço para o trabalho e uma cópia do Projeto Político-Pedagógico (PPP). Os pedidos foram atendidos nas duas EU, sem hesitação ou demora. No dia marcado, tudo estava preparado para a realização das entrevistas. Os professores já haviam participado da etapa do questionário on-line, já tinham conhecimento da pesquisa e assinaram o Termo de Consentimento Livre e Esclarecido para esta etapa.

\section{4}

Informações oferecidas pelas entrevistas semiestruturadas e considerações iniciais

As entrevistas foram gravadas e transcritas (transcrição literal) para facilitar o processo de análise. A fase da decifração estrutural (BARDIN, 2011, p. 95), que consiste em analisar entrevista por entrevista, para compreender as atitudes e os valores que cada pessoa atribuiu à sua relação com o dispositivo, foi realizada para compreendermos os temas de análise.

Em seguida, realizamos a análise categorial (temática), onde desmembramos o texto em unidades (temas), a fim de descobrirmos os núcleos de sentido que configuram a comunicação, e, posteriormente, realizar o reagrupamento em classes. Segundo Bardin (2011, p. 149), a categorização deve apresentar as seguintes qualidades:

a) Exclusão mútua: cada elemento não pode existir em mais de uma divisão;

b) Homogeneidade: um único princípio de classificação deve governar a sua organização;

c) Pertinência: adaptação ao material de análise escolhido, e quando pertence ao quadro teórico definido; 
d) Objetividade e a fidelidade: as diferentes partes de um mesmo material, ao qual se aplica a mesma grade categorial, devem ser codificadas da mesma maneira, mesmo quando submetidas a várias análises;

e) Produtividade: fornecimento de resultados férteis em índices de inferências, em hipóteses novas e em dados exatos.

No momento seguinte, iniciamos o processo das asserções, que conforme Stake (2012, p. 28), são uma mistura escondida de experiências pessoais, trabalho acadêmico e as asserções de outros investigadores. O pesquisador pode apresentar uma ou mais dessas interpretações, atribuindo a elas uma fonte real ou uma fonte genérica.

Nesta mesma linha de raciocínio, Bardin (2011, p. 44), ressalta que a intenção da análise de conteúdo é a inferência de conhecimentos relativos das condições de produção (ou, eventualmente, de recepção), inferência esta que recorre a indicadores (quantitativos ou não).

Aproveitamos para frisar que as condições objetivas de produção do material para análise alteraram levemente a forma como o pesquisador se relacionou com o objeto, alterando, consequentemente, seus instrumentos e estratégias.

Assim, as entrevistas foram analisadas mantendo o foco no objetivo geral desta pesquisa, procurando trazer à tona temáticas que indicassem o percurso de apropriação do tablet educacional pelos(as) docentes do Ensino Médio do DF.

Assim, seguiremos as orientações de Bardin (2011), para quem a análise de conteúdo é

\footnotetext{
Um conjunto de instrumentos metodológicos cada vez mais sutis e em constante aperfeiçoamento, que se aplicam a "discursos" (conteúdos e continentes) extremamente diversificados (p. 15).

Um conjunto de técnicas de análise de comunicação visando obter, por procedimentos sistemáticos e objetivos de descrição do conteúdo das mensagens, indicadores (quantitativos ou não) que permitam a inferência de conhecimentos relativos às condições de produção/recepção destas mensagens (p. 48).
}

Nas orientações desta estudiosa constam três fases:

1) A pré-análise (fase de organização, tendo como função organizar e sistematizar as ideias iniciais, buscando a formulação de um plano de compreensão), iniciada com a leitura "flutuante" (primeiras impressões e iniciativa de formulação de possíveis linhas de pensamento), seguida da escolha dos 
documentos. Nosso universo de pesquisa foi definido pelo questionário on-line e pelas entrevistas semiestruturadas. A formulação de hipóteses deu-se pelo procedimento exploratório, cuja função é apreender as ligações entre as diferentes variáveis.

2) A exploração do material (operações de codificação, decomposição ou enumeração). Quanto ao recorte, tomamos por unidade de registro os temas que remetiam à apropriação do tablet educacional. Assim, emergiram os temas: perfil profissional; habilidade do(a) docente; formação para uso da ferramenta; políticas públicas (níveis macro e micro); diretrizes pedagógicas e didáticas; ambiente de exercício; cultura vivenciada pelos sujeitos e guarda do aparelho. A frequência de aparição e a intensidade dos termos correlatos determinou a regra de enumeração dos temas.

3) O tratamento dos resultados, a inferência e a interpretação. A organização adotada e a compreensão das relações estabelecidas entre os temas permitiram uma leitura qualitativa das informações, atrelada aos dados quantitativos, pois, segundo Bardin (2011, p. 146), a análise qualitativa não rejeita toda e qualquer forma de quantificação.

Exposto o caminho para as análises, passaremos aos resultados.

Com o objetivo de conhecer a prática, ou seja, o uso didático do tablet educacional, perguntamos aos Colaboradores de Pesquisa Etapa Entrevista Semiestruturada (CE) primeiramente sobre suas expectativas com relação à ferramenta. Assim, destacamos as seguintes falas:

CE1: Sim, a ideia é... Como nós já vínhamos trabalhando com uma espécie de DICEL, assim, a gente pegou o... É... Me foge aqui agora. Nós pegamos os nossos diários e colocamos eles em Excel. Só que não era válido oficialmente, né? A gente fazia, depois imprimia e lançava pro diário para não haver rasuras e tal. $E$ aí quando veio então o tablet, foi interessante que culminou com a liberação do DICEL. Então eu pensei, então eu vou pegar o DICEL, vou jogar para um tablet e aí vai ficar muito legal, vai ficar tranquilo, fazia ali a chamada rapidamente e tal. Só que na hora que nós fomos fazer isso a gente teve um problema inicial, que o DICEL, ele é feito é... No Excel, mas ele tem... Ele tem um banco de dados, algo que eu realmente não me lembro o nome, que quando você vai jogar para o tablet ele não lê, ele não aceita, né? Então ele é feito lá e realmente me foge o nome técnico que o DICEL usa. E aí não dá, aí a minha tentativa foi fazer o seguinte: eu vou pegar então o Excel, vou fazer uma planilha somente com o nome dos alunos, número e tal. Do jeito que tá lá eu vou lançar nele e vou só fazer 
chamada. Aí eu iria salvar isso no Dropbox e depois do Dropbox eu ia só copiar e colar.

CE1: Sim, no momento em que eu conseguisse pegar e fazer ele ligar, por exemplo, o Wi-Fi com algum projetor. Então iria pra uma sala. (Ininteligível) Eu iria pra uma sala e eu iria conectá-lo previamente com um projetor, o Wi$\mathrm{Fi}$, o conector, esse projetor estaria ligado na rede da escola. E eu com vídeo ali, iria analisar o vídeo e iria soltar, ou seja, iria ser algo extremamente rápido.

CE2: Tinha sim, achava que de... Por meio do tablet a gente ia desenvolver mais atividade, que seria orientado, né?

CE3: Bom, as expectativas eram expectativas boas, porque a gente tinha um certo conhecimento já do uso desse tipo de tecnologia na Índia. [...] Aí o governo veio com o projeto do tablet no Brasil, um projeto que a gente considerou na época, inclusive, como um projeto arrojado, visto que o jovem está em contato com essas tecnologias o tempo todo. E além dele tá em contato com essas tecnologias, seria uma forma de tá trazendo ela pra dentro da sala de aula, dinamizando a forma de se estudar, agregando o uso dessa tecnologia. E também tornando-se mais interessante tanto por parte do Professor que viria usar essa tecnologia, como por parte do aluno. [...] assim, a gente pensou que poderia ser um projeto arrojado justamente pelo fato de que proporcionaria uma nova metodologia de tá ensinando. Não somente a questão de ter um aparelho em si, mas o que esse aparelho poderia proporcionar, porque você teria na palma da sua mão o acesso a um mundo virtual ali. Porque o tablet não é somente você colocar ali livros digitais, tem a questão do livro digital também que o aluno não teria mais necessidade de ficar carregando quilos e mais quilos de livros, poderia carregar tudo ali no seu dispositivo eletrônico. E, ao mesmo tempo, se a escola tivesse provida de uma boa rede de Internet, você teria ali um mundo mesmo em suas mãos através das redes $\mathrm{Wi}-\mathrm{Fi}$, da Internet que o aluno poderia acessar isso diretamente em seu tablet.

A expectativa apresentada pelos CE também foi constatada pelo depoimento do $C Q$ quando perguntamos que motivos influenciaram a aceitação ou não do tablet educacional. 24 (vinte e quatro) dos 32 (trinta e dois) colaboradores registraram o desejo de trabalhar com a ferramenta para melhorar sua relação com 0 conhecimento, com a didática e até com os estudantes. $O$ ter expectativa, desejar ter, ansiar utilizar e projetar uma melhora foram classificados como o perfil do(a) docente, pois independe da condição técnica ou acadêmica. Refere-se ao que o(a) docente vislumbra, manifesta-se então como fascínio pelo equipamento, fenômeno que pode ser investigado pelo viés da influência da mídia sobre o(a) professor(a).

Ao perguntar sobre a expectativa de uso, surgiu a discussão sobre que características o(a) professor(a) precisava ter para trabalhar com o tablet, assim surgiu o perfil do(a) profissional para uso do tablet educacional. Algumas falas expuseram tal ponto, conforme verificamos abaixo: 
CE1: Ah, ele tem que ter uma vivência com tecnologia, né?

CE3: A primeira coisa: curiosidade, ele tem que gostar de tecnologia, tem que ter curiosidade em tá aprendendo. Ele tá buscando, se ele não tiver essa curiosidade não vai funcionar.

CE4: Bom, a primeira é uma habilidade básica que eu vejo, é gostar de trabalhar com equipamentos eletrônicos. E o segundo mais importante, né? Que é não ter medo de trabalhar com o novo, que cada equipamento novo que chega traz lá as suas peculiaridades, bem como as duas dificuldades, né?

Aqui temos mais um indício do perfil profissional indicado pela curiosidade, pelo gostar de tecnologia, pelo buscar aprender e pela vivência (experimentação). Conforme dados desta pesquisa, tal fator torna-se relevante para pensarmos sobre uma possível apropriação didática das TDICE, pois é neste tema de análise que percebemos a influência do possuir, de quase um fetiche em ser dono e projetar uma utilização na rotina pedagógica.

O tema habilidade do(a) docente surgiu ainda na primeira etapa de perguntas, onde buscávamos caracterizar o(a) docente que se propunha a trabalhar com 0 tablet educacional em sua rotina. Assim, o tema habilidade docente foi selecionado pelas respostas que envolveram o aprendizado adquirido sem instrução formal para uso das tecnologias ou sua necessidade em qualquer plataforma ou aparelho. Foi expresso pela frequência e pertinência em que apareceram no discurso de nossos colaboradores. Assim, apresentamos:

CE1: Já, eu produzo, por exemplo, aplicativo, né? Pra tablets, pra Android, no ambiente Android.

CE1: Ele tem que saber abrir um computador e saber como se desenvolver ali dentro, né? E obviamente, previamente, ele já deve ter feito ali em casa num PowerPoint ou num qualquer outro, né? Editor de vídeo também, porque tem hora que o vídeo é longo e têm coisas que você não quer trabalhar. Então 0 interessante pra um Professor saber trabalhar com tecnologia em sala de aula seria: saber mexer com PowerPoint, saber mexer com Word, saber mexer com todo o ambiente de Windows que a gente é acostumado, né?

CE2: [...] Porque a parte técnica eu já manjava um pouco, uma vez que eu já tinha um contato com um... Eu já tinha um tablet também.

CE2: Não, na verdade os professores usam mais o... A informática, o computador, o notebook mais por causa do diário eletrônico, né? Então hoje, aqui $100 \%$ dos professores têm um notebook e levam pra sala, mas mais em função do diário eletrônico do que usar na disciplina propriamente dita, né? Usa muito Datashow, assim, com figuras, vídeo, mas, tipo, programa mesmo para usar no tablet, programa educacional, até na área de exatas não existe, realmente não existe. 
CE3: [...] mas em compensação em outros se você não tiver um prérequisito, um conhecimento mínimo com relação a como funciona os equipamentos tecnológicos, aí a dificuldade realmente se torna muito grande. Até porque trabalhamos com energia e energia pode a qualquer momento parar e, falando em software, ele pode travar em algum momento. CE3: Quem já tinha o hábito de trabalhar com o tablet não sentiu dificuldade, a dificuldade pairou foi na questão da qualidade mesmo do próprio equipamento, que era uma qualidade inferior ao que o Professor tava acostumado.

As respostas nos remetem aos conhecimentos que o(a) professor(a) precisa ter para trabalhar com o tablet educacional. Este aprendizado pode ser de outras plataformas $^{25}$ (Windows, Linux ou OS X) e seus mais variados programas/aplicativos ou de outras formações para exercício que, mesmo sem ligação direta com o uso de ferramentas tecnológicas, utilizam linguagens e mecanismos digitais (exemplo: cursos em ambiente Moodle).

Posto isto, temos um indício de apropriação didática, a habilidade advinda da experiência com o uso ou a formação para o trabalho com tecnologia. Ter perfil e habilidade sugere um índice maior de posse das ferramentas, não somente do tablet educacional, mas também de outros aparelhos, pois ocorrerá a operação por similaridade.

Quando questionados sobre a rotina escolar e a importância do uso da ferramenta surgiu a discussão sobre a cultura estabelecida pelas relações entre os sujeitos escolares. Assim, identificamos outro tema, a política pública para inclusão de docentes. Esse tema pode ser percebido através dos registros que indicam a discuta de poder, de espaço e de identidade dentro da escola. E esse tema foi tão marcante na pesquisa que alguns colaboradores fizeram questão de expressar suas frustrações, como podemos ver abaixo:

CQ10: Por ser uma coisa nova na rede pública. Imaginei que fosse algo mais sério, que tivesse futuro. Mas no DF a política acaba com tudo, principalmente com coisas boas.

CQ22: Os aluno de hoje só querem saber de celular, então o governo oferece algo parecido... achei melhor aceitar e acreditar que pudesse melhorar 0 interesse deles em estudar. Pensei nas possibilidades de trabalho (vídeos, leituras, pesquisa etc.). É o novo.

CQ26: Não queria participar de mais um circo do governo.

\footnotetext{
${ }^{25}$ Para maiores informações, consultar: Windows (https://www.microsoft.com/pt-br/windows/); Linux (http://www.infowester.com/historia_linux.php); OS X (http://www.apple.com/br/osx/).
} 
CQ31: Não podia aceitar uma ilusão. Com tanto a se fazer nas escolas e o governo gastando com tablet, uma vergonha. Os banheiros não tem porta, 0 teto fica caindo, ou seja, tem coisa mais importante para gastar nosso dinheiro.

Nas entrevistas o tema também apareceu, confirmando sua pertinência.

CE1: Achei assim, até parabenizo, né? A ideia de terem tido essa ideia de trazer o tablet pra nós, só que eu acho que deveria ter tido um equipamento melhor, não é?

CE2: Sim, também, com certeza. E ele foi um projeto que ele... No início teve aquela expectativa, né? Depois foi uma, assim, abandonado e mais com rela... É, teve a influência disso aí, né? Questão... É, política, com certeza. E, mas também faltou realmente a empresa direcionar mais, integrar os professores, principalmente do ensino médio que usa muito a informática, né? E, quer dizer, o projeto foi, terminou sendo um fracasso, esses tablets aí, aliás, foi na verdade um prejuízo até mesmo pro governo, né? Ele gastou tanto e a ferramenta não foi bem utilizada, né?

CE3: [...]Aí o governo veio com o projeto do tablet no Brasil, um projeto que a gente considerou na época, inclusive, como um projeto arrojado, visto que o jovem está em contato com essas tecnologias o tempo todo. $E$ além dele tá em contato com essas tecnologias, seria uma forma de tá trazendo ela pra dentro da sala de aula, dinamizando a forma de se estudar, agregando o uso dessa tecnologia. E também tornando-se mais interessante tanto por parte do Professor que viria usar essa tecnologia, como por parte do aluno. CE3: Olha, é. Em 2013... Se bem que em 2013 eu acho que ainda não, não influenciaria tanto. Ou se o governo pensou que poderia influenciar foi um tiro no pé, por causa justamente da forma como foi implementado, porque eu... Se tinha usado uma ferramenta boa, talvez, teria dado certo, mas a forma como foi implementado realmente não tinha como funcionar.

CE3: Não, olha, assim, eu acho que esse programa, ele não... O governo não deveria deixar esse programa morrer, esse programa acho que deveria ser incentivado, o governo deveria assumir esse tipo de programa, mas de modo sério. De modo sério, ou seja, é... Vamos fazer uma inclusão digital? Vamos, mas vamos fazer de um jeito certo. Vamos colocar uma rede que funcione nas escolas, vamos colocar um dispositivo. Nas mãos dos professores dispositivos eletrônicos que funcionem, nas mãos dos alunos um dispositivo que funcione, mas vamos trabalhar também como isso vai ser feito, né?

CE3: E eu lembro que quando a gente começou ouvir falar que o governo ia adotar o tablet, assim, houve alguns questionamentos, mas o pessoal que estava mais à frente, que coordenava os NTE's, que tinha um contato muito com o MEC, com as instâncias governamentais, você falava: "Não, esse programa vai funcionar, porque isso aí é a menina dos olhos da Dilma na parte de tecnologia."

CE4: É porque entrou num momento conturbado com relação à política. Desculpa, a política do DF, então nós tínhamos aí grupos realmente divididos: uns acreditavam realmente no que tava sendo implantado e outros não. Então essa, vamos dizer assim, desconfiança ou esse momento 
de transição, realmente dificultou um pouco pra que esse projeto fosse aplicado na íntegra.

É possível que seja algo muito específico do DF, devido ao seu tamanho geográfico, relativa facilidade de comunicação e até mesmo por ser um centro de referência da política nacional, mas o fato é que o tema surgiu para orientar a aceitação ou recusa do tablet educacional. Mesmo aqueles(as) que aceitaram foram influenciados(as) pela disputa de espaço, de poder e de identidade gerada por essa discussão.

Ainda na discussão sobre a rotina pedagógica, foi questionado se a mesma havia sido alterada pelo uso do tablet. Ao responder tal questão, o CE2 nos chamou a atenção para a necessidade de uma diretriz de uso pedagógico do tablet educacional, quando registrou que o governo deveria direcionar os professores, que deveria existir um projeto pedagógico claro e direto. No DF não foi lançada uma orientação padrão para que os(as) docentes utilizassem a ferramenta em sala, isso ficou sob a responsabilidade do NTE durante a formação compulsória oferecida pela EAPE. Sobre esse tema registramos:

CE1: A diretriz pedagógica que a gente recebeu foi uma diretriz pedagógica,
digamos assim, geral, né? Tipo, um tablet estaria nas nossas mãos e que
nós iríamos fazer um curso para aprender. E que com o tablet em mãos,
com esse curso, a gente poderia então trabalhar nesse ambiente, mas
assim, direcionado: "Olha, você vai fazer isso." Não foi, até achei
interessante, porque senão a gente iria receber algo pra ser direcionado a
fazer alguma coisa, que talvez não seria, não... Não é o foco da nossa
disciplina e tal, porque cada disciplina tem um foco diferente.
CE2: Com certeza, é. Faltou isso aí, essa, é... Relacionamento com a parte
pedagógica, que ele foi entregue, mas não teve esse acompanhamento,
não teve um direcionamento, acho que faltou, tipo, fazer um trabalho por
escola, né? Com alguém que viesse de fora da universidade, ou da
empresa mesmo do governo, e tentar direcionar isso aí, não foi feito. Tanto
é... Acho que deve ter sido um dos pontos que levou ao fracasso, né?
Porque não foi direcionado para a área pedagógica, como era a finalidade
no início.

Este tema cruzou-se com a expectativa que o(a) docente tinha de ser instruído para utilizar o tablet como ferramenta pedagógica, ou seja, dentro de sala de aula como o(a) professor(a) poderia realizar a junção entre o tablet (o recurso didático) e os conteúdos das disciplinas. Foi comum, tanto no questionário on-line quanto nas entrevistas, a intenção de uso somente para exibição de vídeos e 
realização de pesquisas na internet. Mas nem mesmo isso aconteceu como se esperava, levando a uma não tão boa recepção e execução do programa de inclusão digital de professores.

Tratando-se de diretrizes para uso, perguntamos sobre formação pedagógica, de forma mais direta sobre o curso oferecido pela EAPE. A formação específica já havia sido observada através do questionário on-line, 21,87\% dos CQ mencionaram o termo ou sinônimos. Lembramos que $90,6 \%$ dos colaboradores não tiveram formação didática para o uso de tecnologias em sala de aula, revelando sua necessidade.

A formação foi citada pelos CE, conforme abaixo:

CE2: Eu participei do curso, o curso também muito isolado. Tipo, ele ensinava mais a parte técnica, não a parte pedagógica que era a parte mais importante, né?

CE2: Isso. Então a expectativa era que fosse mais direcionado para a área pedagógica do curso, e ficou mais, assim, como... De como usar mais a ferramenta mesmo, sem relacionamento com a parte pedagógica.

CE4: Sob meu ponto de vista não, porque na realidade essa primeira formação foi uma formação muito básica de apresentação do tablet.

Acreditamos que este tema também interfira na apropriação didática, pois, mesmo que o(a) docente não tenha o perfil e/ou a habilidade, ele(a) poderá ter contato com técnicas e estratégias pedagógicas que trarão maior segurança para a utilização de aparelhos da TDICE em sala de aula, ampliando as possibilidades de ensino-aprendizagem.

O tema ambiente de exercício surgiu na discussão sobre diretriz pedagógica construída na escola, pelos sujeitos escolares. Suas impressões ficaram registradas nas falas abaixo:

CE1: Foi, o tablet educacional foi discutido no dia da entrega, foi discutido que teria um curso, mas assim, sentar e discutir sobre o tablet... Não.

CE1: Deve-se investir um pouco mais. Ah, é... Por exemplo, o ideal seria que cada sala tivesse um projetor, né? Que cada sala tivesse um sistema de áudio próprio. E eu acho, assim, essa seria a tecnologia que hoje o Professor da Secretaria de Educação teria em mãos. Eu sei que falar duma coisa digital que custa não sei quantos mil seria, talvez, ingenuidade minha, né? Mas eu acredito que um projetor em sala com um sistema de áudio seria extremamente interessante.

CE2: E ficou uma coisa meio isolada, né? Aliás, totalmente isolada, né? $\mathrm{E}$ tanto é que ele foi de pouca utilidade, né? 
CE2: O que eu percebo é que a gente ainda trabalha de forma muito isolada com relação a isso, né? Não existe um projeto, assim, pra seguir um norte, se deixa... Um norte, partir da empresa, do governo também pra direcionar os professores, com certeza estaria me... Vai, seria melhor utilizado, né? E é um campo que ainda pode crescer muito.

CE3: se a escola tivesse provida de uma boa rede de Internet, você teria ali um mundo mesmo em suas mãos através das redes $\mathrm{Wi}-\mathrm{Fi}$, da Internet que 0 aluno poderia acessar isso diretamente em seu tablet. Então essa era a expectativa que a gente tinha, só que quando o tablet foi entregue a expectativa, ela foi toda água abaixo, inclusive, a gente foi chamado pra testar o tablet.

CE4: Bom, com relação ao tablet em si é possível fazer muita coisa, né? Dentro de sala de aula, porém, têm algumas vertentes, algumas variáveis que a gente precisa primeiro corrigir. Bom, a primeira delas é a questão do próprio $\mathrm{Wi}-\mathrm{Fi}$, o sinal tem que chegar forte nas salas de aula, porque muitas vezes fica restrito ali à coordenação, à sala dos professores e direção. $\mathrm{E}$ onde é preciso realmente, que seria trabalhar com o aluno, ele não chega, ou se chega com uma qualidade inferior.

CE4: [...] com relação ao ambiente da escola dificultou um pouco, primeiro porque não fazia parte da rotina do Professor. Segundo, muitos foram resistentes a trazer esse novo equipamento, não é nem a questão de ter recebido, né? Mas, assim, levar esse equipamento pra dentro de sala de aula.

Como podemos perceber, esperava-se que a SEEDF e a escola estivessem preparadas para acolher o uso do tablet educacional. Porém, a realidade não contemplou uma das características mais desejadas pelos(as) docentes, a conectividade via Internet. A UE não viabilizou um projeto pedagógico que tivesse como engrenagem mestra o uso do tablet educacional. A análise dos PPP das duas escolas dos CE nem mesmo citam o uso das TDICE na formação dos(as) docentes ou do estudante, apenas anunciam a existência de laboratórios de informática, mas sem nada específico quanto ao que deve ser realizado nesses espaços. Acreditamos que tanto a aceitação quanto a apropriação poderiam ser mais efetivas se a SEEDF tivesse adotado um sistema diferente de escolha e de implementação do disposto, pois segundo Lacerda Santos (2005), a escolha deve ser feita pelo(a) docente, e a sua capacidade de discernimento é essencial, para qual a formação inicial e/ou continuada são subsídios para tal ação.

A cultura estabelecida pelos sujeitos, dentro ou fora da escola, mediada pela tecnologia, foi nosso próximo tema de análise. Estávamos interessados em saber, por exemplo, sobre o planejamento, a seleção de material e conteúdo, se a comunicação institucional utilizou o tablet, se os espaços de ensino foram ampliados. A compreensão desse tema é fundamental para nos aprofundarmos um 
pouco mais na apropriação didática do tablet educacional. Através das entrevistas registramos como os CE expressam tal questão:

CE1: E eu com vídeo ali, iria analisar o vídeo e iria soltar, ou seja, iria ser algo extremamente rápido. Coisa que a gente já faz, por exemplo, na igreja onde o projetor é ligado à rede da igreja e o tablet que a gente tem é ligado à rede da igreja. Lá a gente mexe na mesa de som pelo tablet que tem, mexe com o projetor.

CE2: Essa questão quando for reformular a disciplina aí, acho que é um ponto que tem muito a crescer, né? O que eu percebo é que a gente ainda trabalha de forma muito isolada com relação a isso, né?

CE2: Pra falar do tablet em si, mas parou por aí. É, muita gente até que devolveu o tablet, outros perderam, deram pros filhos e tal.

CE2: [...] acho que faltou, tipo, fazer um trabalho por escola, né? Com alguém que viesse de fora da universidade, ou da empresa mesmo do governo, e tentar direcionar isso aí, não foi feito.

CE3: [...] visto que o jovem está em contato com essas tecnologias o tempo todo. $E$ além dele tá em contato com essas tecnologias, seria uma forma de tá trazendo ela pra dentro da sala de aula, dinamizando a forma de se estudar, agregando o uso dessa tecnologia.

A cultura dos sujeitos perante a tecnologia não parece ser determinante, mas influencia tanto a aceitação quanto a apropriação, pois o(a) docente pode se sentir compelido a utilizar minimamente os dispositivos das TDICE.

$\mathrm{O}(\mathrm{A})$ docente projeta a sua utilização e espera resultados semelhantes, influenciado pelos estudantes que usam os dispositivos tecnológicos ou até mesmo por usos próprios fora do espaço escolar. Até mesmo o costume (cultura) de esperar pela formação institucional esteve presente nas falas.

$\mathrm{Na}$ discussão sobre a ampliação dos espaços de ensino e de aprendizagem, surgiu o tema guarda do aparelho. Este tema de investigação ficou evidente pela menção ao porte e espaços onde o tablet educacional foi utilizado, tendo em vista que, mesmo sendo um patrimônio do GDF, o(a) professor(a) podia levá-lo para casa. Vejamos os registros do CE:

CE1: Trabalhar com o tablet, eu trabalhei durante umas duas semanas experimentando em casa, na escola, mas quando eu fui pra sala de aula eu trabalhei com ele em seis aulas.

CE2: Acho que se fizer uma pesquisa hoje, pouquíssimos professores aqui têm ainda essa ferramenta aí em mãos, né? Uns que devolveram, outros deram pros filhos. $\mathrm{E}$ a finalidade dele foi totalmente extensiva, foi realmente pra aproveitar. 
CE2: Então, atualmente eu tenho um tablet meu mesmo de... É, propriedade minha, eu utilizo em sala, mas mais como um instrumento de trabalho, assim, pro diário, pra facilitar a digitação de prova.

CE3: Não somente a questão de ter um aparelho em si, mas o que esse aparelho poderia proporcionar, porque você teria na palma da sua mão o acesso a um mundo virtual ali.

O sentido de posse atribuído à apropriação didática passa por poder ter escolhido o modelo do dispositivo, por poder levá-lo para onde desejar, por acessar o que quiser e até mesmo por se desfazer do dispositivo quando desejar. As entrevistas indicam que este fato pode ter contribuído para a aceitação, recusa ou devolução (desistência) da ferramenta pedagógica. Assim, não ser dono do dispositivo pode cercear o porte e a liberdade de utilização da ferramenta.

Ao interpelarmos sobre o uso, surgiram com frequência menções à qualidade da ferramenta. Posto isto, outro tema de análise surgiu. E foi muito recorrente nas entrevistas e nos questionários, principalmente nos quesitos hardware e software. Vejamos tais relatos:

CE1: Do hardware, do hardware, porque o aplicativo nem veio nele, eu baixei um outro aplicativo que em um outro tablet funcionava perfeitamente. Era como se eu tivesse fazendo em mãos. Mas nele não foi possível, o deslizar não foi da forma que a gente esperava, o abrir não foi da forma que esperava, pra salvar demorava muito. Então assim, realmente ficou inviável. CE1: Isso, não era viável pra fazer chamada, pra passar vídeo, ele não fazia ligação com o Wi-Fi do projetor. Na verdade o projetor que não tava fazendo a ligação com o Wi-Fi, e aí ficou aquela... Aquele problema, aí assim, didaticamente na hora que alguma coisa não funciona em sala de aula, aí você perde o controle da turma. Até você retomar esse negócio de novo é complicado.

CE1: Não, não teve, né? E assim, só reiterando, eu usei o tablet em sala de aula e quando eu vi que ele não tinha uma interface com os retroprojetores da escola, que também não estavam ligados em Wi-Fi, aí eu nem tentei, né? Então com o Wi-Fi da esco... Com o projetor da escola eu não tentei, mas em sala de aula eu tentei, né?

CE3: E aí os colegas receberam, o tablet e foi um festival de devolução, porque realmente não funcionava. $E$ a gente pôde perceber que qualquer tablet desses mais baratinhos que você compra em qualquer lugar, é... Tinha uma capacidade melhor de performance do que o tablet do MEC, aliás, qualquer smartphone fazia coisa muito melhor do que o tablet do governo distribuiu. [...] Sim, inviabilizou com o fim pedagógico, o seu... O projeto que seria um projeto arrojado, o projeto era bom, no fim acabou sendo aí um projeto fracassado. [...]Só que no fim a coisa se demonstrou aí que não foi exatamente isso. $O$ tablet, ele é muito ruim.

CE4: Primeiro pelo próprio tablet, a qualidade dele caiu bastante, quando nós estávamos discutindo éramos 14 regionais onde tínhamos técnicos que 
trabalham nos NTE's, e que estavam apontando algumas falhas do tablet. E realmente ele no dia a dia, no uso ele se apresentou e isso dificultou bastante a realização do trabalho da forma como a gente tinha planejado.

CE4: Como nós vimos durante o curso, professores que trabalham com iPad, com tablet da Samsung que tem um processador um pouco mais rápido, uma memória maior. Enquanto que pegou esse que é um processador um pouco mais lento, com... Tinha até 16 Gigas de memória, mas a forma como ele trabalhava deixava muito a desejar. A própria conexão com $\mathrm{Wi}-\mathrm{Fi}$, uma série de outros fatores que interferiram de forma negativa no desenvolvimento do trabalho.

O último tema percebido foi a conectividade. O roteiro de entrevista permitiu, sendo flexível, que pudéssemos retomar temas a fim de aprofundá-los ou completálos. Foi neste movimento que conseguimos trabalhar a conexão dos tablets com a Internet. Nos últimos anos temos vivido em um mundo cada vez mais conectado, porém a escola não tem seguido o mesmo rumo. O Censo Escolar $2014^{26}$ mostra que $61 \%$ das escolas de educação básica têm acesso à internet e em $51 \%$ delas a conexão é feita por banda larga. Quantidade maior que em 2010, quando $41 \%$ das escolas tinham acesso à internet. Porém, a escola ter internet não significa que a mesma é suficiente para os mais variados usos. Nas duas escolas visitadas, por conta dos colaboradores de pesquisa, a internet servia em boa parte aos assuntos administrativos. O wi-fi mal chegava até a sala dos professores e os únicos computadores conectados por fio (um computador disponível para uso na sala dos professores) demonstrava uma internet com velocidade de transmissão de dados insuficiente para uma busca rápida.

Os trechos das entrevistas abaixo evidenciam a dificuldade para estabelecer conexão com a internet usando o tablet educacional:

CE3: E, ao mesmo tempo, se a escola tivesse provida de uma boa rede de Internet, você teria ali um mundo mesmo em suas mãos através das redes $\mathrm{Wi}-\mathrm{Fi}$, da Internet que o aluno poderia acessar isso diretamente em seu tablet. Então essa era a expectativa que a gente tinha, só que quando o tablet foi entregue a expectativa, ela foi toda água abaixo [...]

CE3: E tentamos testar a Internet do tablet, não foi possível, porque o MEC... Na sala que a gente foi não tinha rede Wi-Fi funcionando.

CE4: Bom, com relação ao tablet em si é possível fazer muita coisa, né? Dentro de sala de aula, porém, têm algumas vertentes, algumas variáveis que a gente precisa primeiro corrigir. Bom, a primeira delas é a questão do próprio $\mathrm{Wi}-\mathrm{Fi}$, o sinal tem que chegar forte nas salas de aula, porque muitas

\footnotetext{
26 Maiores informações em: <http://www.qedu.org.br/brasil/censoescolar? year $=2014 \&$ dependence $=0$ \&localization $=0$ \&education_stage $=0$ \&item $=>$.
} 
vezes fica restrito ali à coordenação, à sala dos professores e direção. $E$ onde é preciso realmente, que seria trabalhar com o aluno, ele não chega, ou se chega com uma qualidade inferior.

A conexão via Internet não é a única forma de estabelecer conectividade (é possível realizar tal operação por bluetooth, por exemplo), mas é a mais evidente e comum. Assim, tornou-se a mais eficaz no quesito circulação de informação. A partir disso foi estabelecida uma relação de dependência, levando ao bloqueio do trabalho pedagógico no tablet educacional caso a Internet pare de funcionar. 


\section{6}

\section{APROPRIAÇÃO DIDÁTICA DO TABLET EDUCACIONAL}

A análise dos temas, emergidos das falas dos colaboradores de pesquisa, nos conduzem por uma linha de raciocínio que elege os itens abaixo como geradores da apropriação didática dos tablets educacionais:

- Perfil profissional: atitude de curiosidade perante as tecnologias, gostar dessa temática, ter vontade de aprender a usar os dispositivos e as linguagens digitais, não ter medo e desejar construir suas próprias vivências com ela, compõe o primeiro ponto para a apropriação, pois requer apenas a motivação intrínseca (RYAN e DECI, 2002), tida como uma tendência natural para buscar desafios e exercitar as capacidades do sujeito, ou seja, vontade de exercer, realizar, agir que surge no próprio sujeito.

- Habilidade docente: este item faz referência à aprendizagem que o(a) docente tem sobre a ferramenta em si ou outros dispositivos similares. Aqui, qualquer conhecimento que o(a) professor(a) tenha sobre acesso e operação de tais aparelhos fará a diferença no momento de apropriar-se do dispositivo como ferramenta didática. Acreditamos que, com habilidade, o(a) docente se sentirá mais à vontade na criação e adaptação/utilização do tablet educacional, superando, inclusive, obstáculos estruturais que a UE possa apresentar.

- Política pública para inclusão de docentes: este item refere-se aos programas e projetos, bem como às ações originadas desses processos, que visam incluir o(a) professor(a) em um mundo digital. É preciso aqui pensar sobre o poder e sobre aqueles que o disputam. Conforme vimos nas entrevistas, não basta ter a ferramenta e seguir uma série de exigências (porte, guarda, formação e uso), é preciso promover a conquista de espaços de aprendizagem na escola. E ainda procurar desvincular as ações governamentais partidárias das ações que realmente promovem a melhoria do sistema de ensino.

- Diretriz de uso pedagógico: percebemos através das entrevistas que a falta de instruções didáticas claras e diretas dificultou o uso em sala e 
até mesmo nos momentos de formação e planejamento (coordenação pedagógica). Alguns colaboradores afirmaram que o curso contemplou, em boa parte, questões técnicas, ou seja, conhecer o funcionamento do equipamento e sua configuração. Porém, havia uma necessidade maior, a de repensarmos a didática, as rotinas pedagógicas, os conteúdos, os tempos e espaços de ensino e de aprendizagem. Portanto, a diretriz pedagógica para uso do tablet educacional coloca-se como um fator importante na apropriação didática dessa ferramenta. Ressaltando que tal diretriz não pode engessar as práticas pedagógicas, elas seriam um ponto de partida, uma referência de uso para que, a partir dela, o(a) professor(a) fosse incluído digitalmente.

- Formação didática docente para uso das tecnologias digitais: já é conhecida a deficiência no atual modelo de formação de professores(as) para o uso das tecnologias digitais, e Lacerda Santos e Andrade (2010), bem como Vipo (2016), expõem a ausência de uma formação didática para o uso de tecnologias digitais considerada, neste trabalho, um ponto crucial para a apropriação didática, tendo em vista a crescente utilização dos dispositivos digitais e da internet em nossa sociedade. Tal fenômeno compele o(a) futuro professor(a) e o(a) atual a ter de trabalhar de uma maneira cada vez mais distante da realidade vivida por boa parte dos(as) estudantes do DF, principalmente se focarmos no público-alvo do Ensino Médio.

- Ambiente de exercício profissional: a escola como espaço de formação, de ensino e de aprendizagem, deve ou deveria oferecer não somente as condições estruturais para o uso do tablet educacional, com também deveria fomentar o uso de tecnologias digitais, tendo em vista a quantidade crescente de pessoas que portam tais dispositivos neste espaço e o utilizam durante a realização de suas atividades. Assim, a escola deve reconhecer estes dispositivos como ferramentas didáticas e iniciar o processo de construção de projetos pedagógicos, melhorar a comunicação institucional pela utilização deles e ainda repensar as estratégias em sala de aula com currículo.

- A cultura dos sujeitos: as entrevistas revelaram que o costume de usar aparelhos similares fora da escola, em situações não diretamente 
ligadas à educação, interfere de forma positiva não somente na expectativa que o(a) docente tem do tablet educacional, mas também do próprio, pois o(a) docente busca reproduzir o uso, como se buscasse uma sobreposição didática. Outra face da cultura revelada em nossa pesquisa foi a de esperar pela formação institucional, aquela oferecida pela SEEDF através da EAPE. Mas vale lembrar de Perrenoud (2000), quando este estudioso afirma que o(a) professor é responsável por sua própria formação. Assim, um ponto da apropriação didática é buscar por sua formação, seja por participação em cursos ou em fóruns pela internet. Nesta procura por melhorar a qualidade da ação pedagógica vale recorrer até mesmo ao Youtube $e^{27}$, o que seria mais uma forma de apropriação da linguagem digital.

- Guarda do aparelho: o(a) docente assinou o termo de permissão e guarda do tablet educacional (anexo 01). Portanto, ele(a) sabia que o aparelho não the pertencia, mas que poderia levá-lo para casa e, teoricamente, usá-lo como bem entendesse. Porém, a apropriação didática, no sentido que estamos construindo neste trabalho, exige que o(a) docente seja dono do dispositivo, e não apenas o tenha emprestado. $\mathrm{O}(\mathrm{A})$ professor(a), como membro dessa sociedade informatizada, no uso desses dispositivos, acaba extrapolando os limites de seu horário de trabalho, levando tarefas para sua residência. Isso ficou claro nas entrevistas, o patrimônio da SEEDF foi levado para casa para ser testado, utilizado. $\mathrm{O}(\mathrm{A})$ docente queria se sentir não somente incluído, mas como um membro de uma comunidade que está sempre conectado, antenado. Apareceu em apenas uma entrevista, então acreditamos não ser algo generalizado, mas nos chamou atenção a possibilidade do tablet educacional ter sido dado para uso de membros da família. Não é objetivo dessa pesquisa investigar tal situação, mas esta ação também caracteriza guarda e posse do tablet educacional.

- Ferramenta (hardware e software): vários colaboradores afirmaram que a qualidade do dispositivo (processamento, tela, memória e aplicativos) foi um ponto que pesou na decisão de permanecer com o tablet

\footnotetext{
${ }^{27}$ Para maiores informações, visite <https://www. youtube.com/?hl=pt\&gl=BR>.
} 
educacional. $\mathrm{O}(\mathrm{A})$ professor(a) aceitou, porém não conseguiu trabalhar com ele devido à baixa qualidade. Foram citados, com muita frequência: memória insuficiente, processamento lento, problemas com conexão e tela touch screen ruim. Os aplicativos disponíveis para uso no tablet educacional não foram citados de forma suficiente para análise. O(A) docente tentou usar, mas os obstáculos foram demais para a superação. Assim, podemos afirmar que a qualidade do dispositivo interfere diretamente no uso pedagógico. A tabela 4, sobre as impressões dos(as) docentes sobre o tablet educacional, evidencia a importância da qualidade da ferramenta na apropriação didática.

- Conectividade: um dos preceitos dessa ferramenta é a de poder estar conecta (internet wi-fi) e manter contato com informações e outras linguagens. Mas nossos colaboradores registraram que o dispositivo tem problemas físicos para se conectar à internet e que a escola não oferece wi-fi na qualidade e quantidade suficiente. Desta forma, sem conectividade, o dispositivo perde um pouco de seu objetivo e limita a ação do(a) docente, bem como se torna objeto de frustação. Assim, a conectividade entra como um ponto crucial para a apropriação do tablet educacional.

A figura abaixo ilustra os fatores que interferem na apropriação didática das TDICE, em especial do tablet educacional, enquanto dispositivo, e também, acreditamos, de outros dispositivos similares (smartphones, por exemplo), levantados nesta pesquisa.

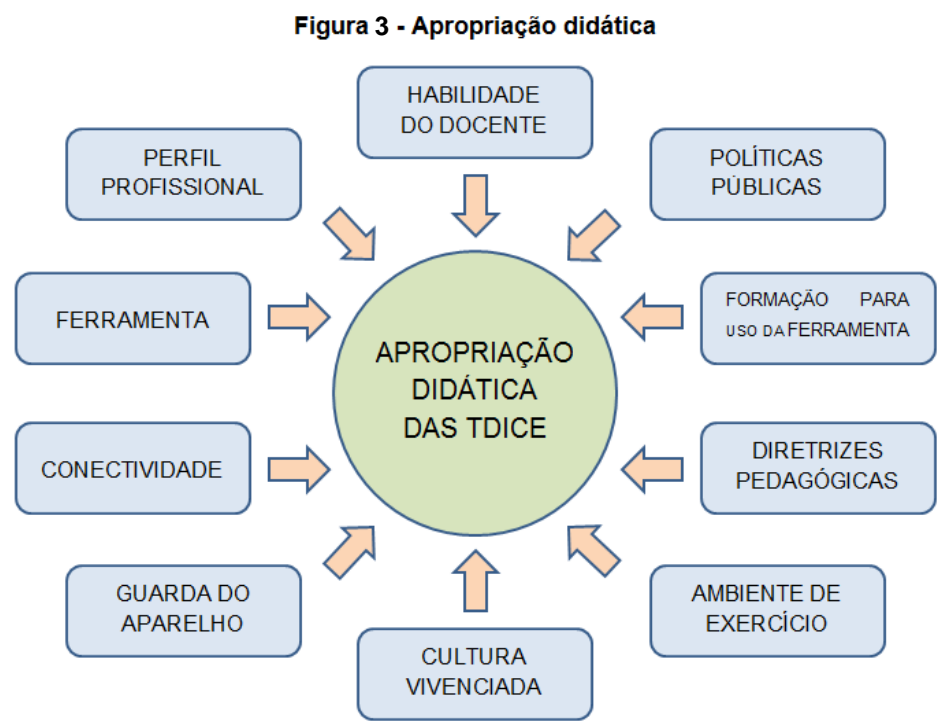


Um dos objetivos específicos desta dissertação é caracterizar o uso, mau uso ou desuso pedagógico do tablet educacional, assim, destacaremos alguns trechos dos questionários e das entrevistas que nos indiquem como ela tem acontecido na prática dos(as) docentes.

O questionário on-line mostrou que $33,3 \%$ dos colaboradores da pesquisa etapa questionário citaram algum tipo de utilização didática do tablet educacional. Destes, 6 (seis) citaram utilizar o tablet educacional como ferramenta para exibição de vídeos, 1 (um) afirmou utilizá-lo para pesquisas de informações e 2 (dois) não especificaram o tipo de uso.

Nas entrevistas o tema foi percebido conforme abaixo:

CE1: E aí não dá, aí a minha tentativa foi fazer o seguinte: eu vou pegar então o Excel, vou fazer uma planilha somente com o nome dos alunos, número e tal. Do jeito que tá lá eu vou lançar nele e vou só fazer chamada. Aí eu iria salvar isso no Dropbox28 e depois do Dropbox eu ia só copiar e colar.

CE1: Eu iria pra uma sala e eu iria conectá-lo previamente com um projetor, o $\mathrm{Wi}-\mathrm{Fi}$, o conector, esse projetor estaria ligado na rede da escola. E eu com vídeo ali, iria analisar o vídeo e iria soltar, ou seja, iria ser algo extremamente rápido.

CE1: E assim, só reiterando, eu usei o tablet em sala de aula e quando eu vi que ele não tinha uma interface com os retroprojetores da escola, que também não estavam ligados em Wi-Fi, aí eu nem tentei, né? Então com o Wi-Fi da esco... Com o projetor da escola eu não tentei, mas em sala de aula eu tentei, né?

CE4: E, por fim, seria um projeto, como esse Professor estaria trabalhando com esse material em sala de aula. Lembro bem que um software carrochefe foi o Angry Birds. Por quê? Muitas cores, além de ser um da época, um software da moda que muitos alunos se interessavam. E os professores também poderiam usar em várias disciplinas, por exemplo, física, eles poderiam usar em artes e matemática, porque você pega ali um bonequinho, faz um lançamento, faz um arremesso. Então ele tinha que calcular a distância, ângulo, força, pra poder atingir um determinado alvo, ou até mesmo com relação às cores, né? As diversas cores que facilitam ou não chamar atenção do usuário, ou seja, você tá trabalhando com um jogo, além da própria estratégia você tem as cores, né? O que representa cada uma?

Como podemos verificar, o uso pedagógico ficou caracterizado como sobreposição didática. $\mathrm{O}(\mathrm{A})$ docente entendeu-o como forma de agilizar o trabalho 28 Maiores informações podem ser obtidas https://www.dropbox.com/pt_BR/business?home=true\&_tk=sem_b_goog\&_camp=sem-b-googbrazil\&_kw=\%2Bo\%20que\%20\%C3\%A9\%20\%2Bdropbox|b\&_ad=44955387222|1t1|c\&gclid=CJ_f0Jv 2oswCFcclkQodkrMImA>. 
pedagógico burocrático (preencher diário), como forma de busca de informações (pesquisa em sites de busca) e exibição de vídeos (uso similar ao da TV e do DVD). Ou seja, o tablet educacional não promoveu o surgimento de novas estratégias didáticas, mantendo o status de promessa pedagógica.

Já o CE4 mostrou uma perspectiva interessante, a de usar um aplicativo já conhecido pelos(as) estudantes para trabalhar os conteúdos. Mas novamente caracterizou-se sobreposição didática.

Não foi percebido nenhum item de mau uso, pois o mesmo poderia ser caracterizado como acesso a sites não apropriados para trabalho em sala de aula ou inúteis/pouco úteis ao planejamento do ensino. Na questão 4 de nosso questionário, $100 \%$ dos colaboradores afirmaram não utilizarem o tablet educacional para jogos, apesar do(a) professor(a) poder utilizar jogos para o trabalho curricular, como vimos na entrevista do CE4.

Mas ressaltamos que, tendo o critério da guarda e esse sendo entendido como tomar posse, o(a) docente poderia utilizar o tablet como instrumento de entretenimento. É possível que os(as) profissionais tenham evitado tal ação por terem consciência de que o tablet é uma ferramenta de trabalho e propriedade do GDF. 
7

\section{CONSIDERAÇÕES FINAIS}

A análise dos temas selecionados nas entrevistas revelou que a apropriação didática, tida como uma postura pedagógica que envolve a participação ativa do(a) docente na construção de linguagens, estratégias e métodos próprios para a utilização de ferramentas (dispositivos tecnológicos) que possibilitem a maximização da ação didática, promovendo ensino e aprendizagem com interatividade, imaginação e criatividade em práticas inovadoras, não aconteceu.

Devido a questões ligadas à apropriação didática, o uso do tablet educacional em sala de aula resumiu-se às tentativas de uso corriqueiro e muito próximas do uso de aparelhos já tradicionais na escola, como a TV, o DVD e o aparelho de som. Ou seja, o(a) professor(a) tentou usar didaticamente a ferramenta pedagógica digital como usaria a TV ligada ao DVD, somente para exibição de vídeos ou para reprodução de músicas. Outro uso muito comum nas entrevistas foi a tentativa de preencher o diário eletrônico, um esforço de ser mais eficiente nesta atividade, como cumprimento de obrigações burocráticas.

Desta forma, resgatando os objetivos específicos deste trabalho, temos:

a) Conhecer os motivos que levaram o(a) docente a não aceitar/aceitar, não ficar/ficar e não usar/usar o tablet educacional em sua rotina pedagógica;

Por meio das análise de dados conseguimos conhecer os motivos da aceitação do tablet educacional. Os(As) professores acreditaram que poderiam trabalhar de forma criativa, conectada e assim oferecer uma aula mais atrativa e eficaz, por isso aceitaram receber a ferramenta.

Os(As) docentes que recusaram o tablet educacional, em sua maioria, conforme dados desta pesquisa, o fizeram devido a protesto político, por acreditarem que assim não compactuariam com as políticas públicas para a Educação do DF, ou reconheceram que não estavam preparados(as) para utilizar a ferramenta pedagógica em sua prática.

Já a questão de ficar com o tablet educacional, manter a guarda, foi relacionada à qualidade do mesmo. Boa parte dos colaboradores dessa pesquisa afirmou que as características da ferramenta foram decisivas para permanecer ou 
não com guarda, pois não faz sentido continuar responsável por algo que não será utilizado durante o trabalho.

O uso ou não do tablet educacional na rotina pedagógica, como ferramenta didática, ficou condicionado às condições objetivas de trabalho, ou seja, se havia conexão com a internet, se a UE organizou ações ou projetos pedagógicos que incluíssem tal dispositivo, se houve incentivo institucional. Em uma parte considerável de nossas entrevistas tais questões interferiram de forma a dificultar o uso didático, fazendo, inclusive, com que o (a)docente desistisse de utilizar.

b) Verificar se houve mudança na rotina pedagógica dos(as) docentes que usaram o tablet educacional;

As entrevistas com os colaboradores de pesquisa que usaram o tablet educacional revelaram que não houve mudança na rotina pedagógica, e a ferramenta não produziu o efeito desejado e anunciado pelo governador no ato de lançamento do projeto. Assim, podemos afirmar que o tablet educacional não ajudou o(a) professor(a) na didática e nem tornou a escola mais prazerosa para o grupo pesquisado. A prática docente não foi alterada com a inserção do tablet educacional, mas é possível verificar que o(a) docente foi afetado pelo projeto, pois ficou clara a frustação de não ser cumprida a expectativa inicial. Fato que gerou o desuso do equipamento (interrupção da utilização).

c) Caracterizar o uso e o mau uso pedagógico do tablet educacional, de acordo com a premissa do Programa Nacional de Tecnologia Educacional (Prolnfo).

Sobre este objetivo podemos indicar que, mesmo com todas as dificuldades, o(a) docente buscou usar o tablet educacional para a melhoria de seu exercício e não foi verificado nenhum tipo de mau uso nesse processo. $O(A)$ professor(a) permaneceu fiel à premissa do Prolnfo. Acreditamos que o suporte ao(à) professor(a) foi falho no tocante à formação para uso, qualidade técnica do tablet e conectividade com a internet. Se estes itens fossem oferecidos de forma suficiente o uso pedagógico poderia ser outro, bem mais próximo da expectativa do(a) docente e até mesmo do GDF.

Posto isto, partimos para o objetivo geral, analisar como tem sido o percurso de apropriação didática do tablet educacional, fornecido pelo GDF, pelos(as) docentes do Ensino Médio da Rede Pública de Ensino.

Após todas essas análises e de termos percorrido os objetivos específicos, percebemos que tanto o MEC, quanto a SEEDF, deveriam ter levado em conta, em 
relação ao uso do tablet educacional: o perfil profissional (gostar de tecnologia, ter curiosidade, busca pela aprendizagem e desejo de inovar); habilidade do docente (conhecimento adquirido em instruções antes do uso do tablet educacional); políticas públicas (disputa de poder e identidade, principalmente voltadas para a valorização profissional); diretriz pedagógica (projetos pedagógicos e instruções mais claras sobre a utilização desejada); formação para uso da ferramenta (curso que versasse não somente sobre as questões técnicas, mas também e principalmente sobre as questões pedagógicas); ambiente de exercício (discussão pedagógica durante momentos de planejamento pedagógico, sistema físico de internet sem fio e uso do aparelho pela própria UE na comunicação institucional); cultura vivenciada (uso comum dos estudantes e do corpo docente de tecnologias similares); guarda do aparelho (porte, posse e liberdade de uso); conectividade (oferecimento da internet sem fio - wi-fi) e a ferramenta (qualidade do hardware e dos softwares). Sem estes itens a apropriação didática não se realiza, e o percurso para isso apresenta várias lacunas que dificultam o seu progresso.

É possível realizar um caminho diferente do atual, com a mesma ferramenta ou com outra que se coloque na mesma situação. Mas é preciso repensar o processo de escolha do aparelho, melhorar as condições para o trabalho nas escolas e estruturar a formação docente com base no currículo a ser trabalhado. Em uma projeção, é possível que este processo se torne mais eficiente que o atual, garantindo não somente o sucesso do programa, mas também a inclusão digital docente.

E preciso também, neste momento, reconhecer as limitações dessa pesquisa. Sabemos que, como qualquer produção acadêmica, suas técnicas, instrumentos e resultados estão ligados ao contexto histórico, social e cultural de seus participantes. Portanto, coloca-se como limitada e falha, carecendo de revisão sempre que sua aplicação for requerida.

Diante do carácter de complementaridade do cenário das pesquisas sobre a utilização de tecnologias em sala de aula pelos(as) docentes, esta pesquisa convergiu com as citadas no capítulo 2 , no sentido de indicar que ainda há a necessidade de incluir o(a) docente nas discussões e práticas pedagógicas que envolvam as TDICE. E marcou sua contribuição ao iniciar a discussão sobre apropriação didática e a necessidade de fomentar uma postura docente diferente no trabalho pedagógico no tocante ao uso de tecnologias digitais. 
Um possível rumo novo ou continuidade para essa pesquisa estaria em uma pesquisa-ação voltada para a tomada de consciência da necessidade da apropriação didática das TDICE no espaço escolar, para a construção coletiva de condições para uso das ferramentas tecnológicas, para a discussão e a formulação de projetos curriculares interdisciplinares e para a transformação da prática docente e discente. Bem como também seria interessante refazermos o roteiro de investigação com sujeitos que utilizaram o tablet educacional de forma plena, sem tantos obstáculos à apropriação didática. Assim, teríamos uma base mais ampla e consistente para compreendermos o fenômeno da utilização de TDICE nas escolas.

Concluímos registrando que produzir conhecimento está diretamente ligado à tomada de decisões e, obviamente, às suas consequências. Estamos cientes dos rumos que tomamos e dos resultados que descobrimos, mas o mais importante é que

Talvez não tenhamos conseguido fazer o melhor, mas lutamos para que o melhor fosse feito. Não somos o que deveríamos ser, não somos o que iremos ser...

Mas, graças a Deus, não somos o que éramos.

Martin Luther King (ativista político estadunidense) 


\section{8}

\section{REFERÊNCIAS BIBLIOGRÁFICAS}

AFONSO, C. Professores e computadores: representações, atitudes e comportamentos. Portugal: Edições Asa/Clube do Professor,1993. (Coleção Horizontes da Didáctica).

ALAVA, S. Ciberespaço e formações abertas: rumo a novas práticas educacionais? Porto Alegre: Artmed, 2002.

ANDRÉ, M. E. D. A. de. Estudo de caso em pesquisa e avaliação educacional. Brasília: Liber Livro, 2005.

BARDIN, L. Análise de Conteúdo. São Paulo: Edições 70, 2011.

BRASIL. Câmara dos deputados. Um Computador por Aluno: a experiência brasileira. Brasília: Coordenação de publicações, 2008. 102 p. (Série avaliação de políticas públicas, n. 1).

CORREIA, J. A. Inovação Pedagógica e Formação de Professores. 2. ed. Portugal: Editora ASA, 1991. (Coleção Biblioteca Básica de Educação e de Ensino).

CRUZ, T. C.; MATOS, F. C. C. A tecnologia móvel como perspectiva pedagógica na educação: tablets. In: VI FÓRUM INTERNACIONAL DE PEDAGOGIA, v. 1, n. 1, jul./ago. 2014, Santa Maria/RS. Disponível em: <http://www.editorarealize.com.br/revistas/fiped/trabalhos/Modalidade_2datahora_25 _05_2014_21_39_11_idinscrito_1443_18ae60135b540e74654a1975c7504c78.pdf>. Acesso em: 13 maio 2015, às $15 \mathrm{~h} 30 \mathrm{~min}$.

CUNHA, M. I. da. Inovações pedagógicas: o desafio da reconfiguração de saberes na docência universitária. Cadernos Pedagogia Universitária, USP, 2008.

DEMO, P. Formação permanente e tecnologias educacionais. Petrópolis/RJ: Vozes, 2006.

FAHL, D. et al. O uso de Tablets Educacionais no Ensino Médio. In: Salão do Conhecimento, 2013, ljui. Jornada de Extensão - Ciências Exatas e da Terra, 2013. 
Disponível

em:

<https://revistas.unijui.edu.br/index.php/salaoconhecimento/article/view/2367/0> Acesso em: 13 maio 2015, às 15h10min.

FALCÃO, A. B. de F. Interações entre professores e alunos em situações de ensino-aprendizagem mediadas por NTICE: Retratos do Projeto UCA no Distrito Federal (DF). 2012. 97 f. Dissertação (Mestrado em Educação) - Universidade de Brasília, Brasília, 2012.

FERREIRA, A. B. de H. Miniaurélio Século XXI Escolar: o minidicionário da língua portuguesa. 4. ed. Rio de Janeiro: Nova Fronteira, 2000.

FERREIRA, M. Inclusão digital de professores da SEEDF: um estudo sobre a formação docente. 2009. 138 p. Dissertação (Mestrado em Educação) Universidade de Brasília, Brasília, 2009.

FERRETTI, C. J. A inovação na perspectiva pedagógica. In: GARCIA, W. E. (Coord.). Inovação educacional no Brasil: problemas e perspectivas. São Paulo: Cortez/Autores Associados, 1980.

FONSECA, A. A Internet como Mediadora de Ensino e Aprendizagem de Conteúdos Dinâmicos em Educação Ambiental: um estudo de caso. 2005. Dissertação (Mestrado em Educação) - Universidade de Brasília, Brasília, 2005.

FRANCO, C. de P. Nativos digitais: quem são? Revista Presença Pedagógica: diálogo entre universidade e educação básica para formação do professor. Belo Horizonte/MG: Ed. Dimensão, v. 19, n. 111, p. 24-29, maio/ jun. 2013.

GARCIA, C. M. Formação de Professores para uma mudança educativa. v. 2. Porto: Porto Editora, 1999. (Coleção Ciência da Educação).

GDF/SEEDF. Currículo em Movimento da Educação Básica: Ensino Médio. Brasília/ DF: GDF/ SEDF, 2013.

GIACOMAZZO, G. F.; FIUZA, P. J. A implantação do tablet educacional na perspectiva dos professores. Revista Tecnologias na Educação, v. 11, p. 1-10, 2014. 
GIANOLLA, R. Informática na educação: representações do cotidiano. 3. ed. São Paulo: Cortez, 2006.

GIL, A. C. Métodos e Técnicas de Pesquisa Social. 6. ed. São Paulo: Atlas, 2008. IMBERNÓN, F. Formação permanente do professorado: novas tendências. São Paulo: Cortez, 2009.

KENSKI, V. M. Gestão e uso das mídias em projetos de educação a distância. In: Associação Brasileira de Educação a Distância. Trabalhos científicos, $12^{\circ}$ Congresso Internacional ABED de Educação a Distância. Florianópolis, Brasil: ABED. 2005.

Disponível

em: <http://www.abed.org.br/congresso2005/por/pdf/115tce5.pdf> Acesso em: 29 maio 2013.

. Educação e tecnologias: o novo ritmo da informação. 8. ed. Campinas/SP: Papirus, 2012.

LACERDA SANTOS, G.; ANDRADE, J. B. F. de. Virtualizando a escola: migrações docentes rumo à sala de aula virtual. Brasília: Liber Livro, 2010.

Uma pesquisa longitudinal sobre professores e computadores. Educação \& Realidade, Porto Alegre (RS): UFRS, v. 36, p. 837-848, 2011. Disponível em: <http://www.seer.ufrgs.br/index.php/educacaoerealidade/article/view/23080/14352>. Acesso em: 12 jan. 2016.

; BRAGA, C. B. Tablets, laptops, computadores e crianças pequenas: novas linguagens, velhas situações na educação infantil. Brasília: Liber Livro, 2012.

A promoção da inclusão digital de professores em exercício: uma pesquisa de síntese sobre aproximações entre professores, novas mídias e manifestações culturais emergentes na escola. Revista Interação, Goiânia, v. 39, n. $3, \quad$ p. 529-534, 2014. Disponível em: <http://www.revistas.ufg.br/index.php/interacao/article/view/28790/17722> Acesso em: 12 jun. 2015, às 9h32min. 
LEMOS, A. Cibercultura: tecnologia e vida social na cultura contemporânea. 5. ed. Porto Alegre: Sulina, 2010.

LÉVY, P. As tecnologias da inteligência: o futuro do pensamento na era da informática. Rio de Janeiro: Ed. 34, 1993.

A inteligência coletiva: por uma antropologia do ciberespaço. 3 ed. São Paulo: Loyola, 2000a.

Cibercultura. Rio de Janeiro: Ed. 34, 2000b.

LINS, C. V.; BIGATI, F. L.; LOPES, L. C. L. As dificuldades e resistências dos docentes de uma escola pública de Marataízes ao uso das novas tecnologias. In: Seminário Municipal de Ciência, Tecnologia e Inovação, Faculdade Castelo Branco, 2013.2 Disponível em: <http://sistemas.fcb.edu.br/Eventos/detalhes/anais.jsp?id=37> Acesso em: 13 maio 2015 , às $15 \mathrm{~h} 16 \mathrm{~min}$.

LÜCK, H. Dimensões de gestão escolar e suas competências. Curitiba: Positivo, 2009.

MARCONI, M. de A.; LAKATOS, E. M. Metodologia do trabalho científico: procedimentos básicos, pesquisa bibliográfica, projeto e relatórios, publicações e trabalhos científicos. 4. ed. São Paulo: Atlas, 1992.

Fundamentos de metodologia científica. 5. ed. São Paulo: Atlas, 2003.

MINAYO, M. C. de S. (Org.). Pesquisa Social: teoria, método e criatividade. 2. ed. Petrópolis/ RJ: Vozes: 1994.

NASCENTES, A. Dicionário da Língua Portuguesa da Academia Brasileira de Letras. Rio de Janeiro: Bloch Ed., 1998.

OLIVEIRA, Z. L. C. de; BELCHIOR, J. R. Emprego em TICs e gênero no ramo de informática: uma primeira exploração. Revista Ciências Sociais Unisinos, Porto Alegre/RS, v. 45, n.1, p. 27-33, jan./abr. 2009. Disponível em: <http://revistas.unisinos.br/index.php/ciencias_sociais/article/view/4882> Acesso em: 10 jul. 2015, às 23h11min. 
PERRENOUD, P. Dez novas competências para ensinar. Porto Alegre: Artmed, 2000.

PRENSKY, M. Digital Natives, Digital Immigrants. MCB University Press, v.9, n.5, Oct. 2001. Disponível em: <http://www.marcprensky.com/writing/Prensky\%20\%20Digital\%20Natives,\%20Digital\%20Immigrants\%20-\%20Part1.pdf > Acesso em: 14 jan. 2016, às 22h15min.

QUARESMA, C. R. et al. Tecnologias na educação: inclusão digital dos professores da rede estadual a partir da implementação do programa tablet educacional. RENOTE. Revista Novas Tecnologias na Educação , v. 12, n. 1, jul. 2014. Disponível em: <http://seer.ufrgs.br/index.php/renote/article/view/49820/31180>. Acesso em: 13 maio 2015, às 16h02min.

REBECCHI, E. O sujeito frente à inovação tecnológica. Petrópolis/RJ: Vozes, 1990.

ROSA, M. V. de F. P. do C. R.; ARNOLDI, M. A. G. C. A entrevista na pesquisa qualitativa: mecanismos para validação dos resultados. Belo Horizonte: Autêntica, 2008.

ROGOFF, B. Observing Sociocultural Activity on Three Planes: Participatory Appropriation, Guided Participation and Apprenticeship. In: WERTSCH, J. V.; DEL RIO, P.; ALVAREZ, A. (Eds.). Sociocultural Studies of Mind. Cambridge, USA: Cambridge University Press, 1995, p. 139-164. Disponível em: http://people.ucsc.edu/ gwells/Files/Courses Folder/documents/Rogoff.PartAppr.pdf. Acesso em: 28 maio 2015, às 20h15min.

RÜDIGER, F. Introdução às teorias da cibercultura: perspectiva do pensamento tecnológico contemporâneo. Porto Alegre: Sulina, 2007.

As teorias da cibercultura: perspectivas, questões e autores. 2. ed. Porto Alegre: Sulina, 2013.

RYAN, R. M.; DECI, E. L. Overview of self-determination theory: an organismic dialectical perspective. In: DECI, E. L.; RYAN, R. M. (Ed.). Handbook of selfdetermination research. Rochester: University of Rochester Press, 2002. Cap.1, p.3-33.

Disponível em: 
<http://www.elaborer.org/cours/A14/lectures/Ryan2004.pdf>. Acesso em: $14 \mathrm{fev}$. 2016.

SAMPAIO, M. N. LEITE, L. S. Alfabetização tecnológica do professor. 4 ed. Petrópolis/ RJ: Vozes, 2004.

SILVA, M. C. P. da. O computador na perspectiva do desenvolvimento profissional do professor. 1997. 140 f. Tese (Doutorado em Educação) Universidade Estadual de Campinas, São Paulo, 1997.

STAKE, R. E. A arte da investigação com Estudos de Caso. 3. ed. Lisboa: Fundação Calouste Gulbenkian, 2012.

SZYMANSKI, H.; ALMEIDA, L. R. de; PRANDINI, R. C. A. R. A entrevista na pesquisa em educação: a prática reflexiva. 2. ed. Brasília: Liber Livro, 2008.

VIPO, D. Inclusão digital de professores da Secretaria de Educação do Distrito Federal: um estudo sobre a formação docente. 2016, Dissertação (Mestrado em Educação) - Universidade de Brasília, Brasília, 2016.

WEISER, M. The Computer for the 21st Century. Scientific American, v. 265, n. 3, Setembro, p. $94-104,1991$. 


\section{APÊNDICE A}

- José Wrigell <pesquisadortdice@gmail.com>

$29 / 11 / 15$

para

Saudações!

Nobre colega,

Meu nome é José W. M. Rodrigues e sou professor da SEEDF.

Estou na fase final do Mestrado Acadêmico em Educação pela UnB.

Assim, estou desenvolvendo uma pesquisa, sob orientação do Prof. Dr: Gilberto Lacerda, cujo foco é a apropriação didática das tecnologias digitais pelos docentes, em especial do Tablet Educacional disponibilizado pelo GDF.

E gostaria de contar com sua contribuição neste trabalho, dedicando, no máximo, 15 minutos de seu tempo para responder um questionário online.

Seu sigilo será mantido e as informações serão de grande valia, não somente para a realização da dissertação, mas também para a compreensão dessa nova realidade educacional.

Conto com sua compreensão e colaboração.

Muito obrigado.

José Wrigell.

Segue link:

https://docs.google.com/forms/d/IKR_YebgD67KSmaFsxvDlePFvigqvMg0HeS7ESHM5ggY/viewform? $u$ isp=send form

Qualquer dívida entre em contato.

E caso queria participar da próxima etapa da pesquisa (entrevista), manifeste-se através do e-mail (pesquisadortdice(agmail.com). 


\section{APÊNDICE B}

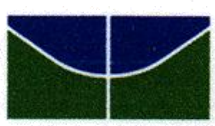

Universidade de Brasília - UnB

Faculdade de Educação - FE

Programa de Pós-Graduação em Educação - PPGE

\section{Termo de Consentimento Livre e Esclarecido - TCLE}

O (a) Senhor (a) está sendo convidado (a) a participar da pesquisa intitulada Apropriação Didática do Tablet Educacional por Docentes do Ensino Médio da Secretaria de Estado de Educação do Distrito Federal, desenvolvida pelo pesquisador José Wrigell Menezes Rodrigues, no âmbito do Programa de Pós-Graduação em Educação, da Faculdade de Educação, da Universidade de Brasília, como parte do Mestrado Acadêmico em Educação.

O objetivo principal desta pesquisa é analisar como tem sido percurso de apropriação didática do tablet educacional, fornecido pelo Governo do Distrito Federal, pelos (as) docentes do Ensino Médio da Rede Pública de Ensino. Seus objetivos específicos são: conhecer os motivos que levaram o (a) docente a não aceitar/ aceitar, não ficar/ ficar e não usar/ usar o tablet educacional em sua rotina pedagógica; verificar se houve mudança na rotina pedagógica dos (as) docentes que usam o tablet educacional; e caracterizar o uso e o desuso pedagógico do tablet educacional, de acordo com a premissa do Programa Nacional de Tecnologia Educacional (ProInfo)

O (A) senhor (a) receberá todos os esclarecimentos necessários antes e no decorrer da pesquisa e lhe asseguramos que seu nome não aparecerá, sendo mantido o mais rigoroso sigilo através da omissão total de quaisquer informações que permitam identificá-lo (a).

A sua participação será através de uma entrevista que será gravada e posteriormente transcrita. $\mathrm{O}$ procedimento tem um tempo estimado em 30 minutos para sua realização. Informamos que você pode se recusar a responder (ou participar) de qualquer procedimento, qualquer questão que the traga constrangimento, podendo desistir em qualquer momento, sem nenhum prejuízo para você. Sua participação é voluntária, isto é, não há pagamento por sua colaboração.

Os resultados da pesquisa serão divulgados na Universidade de Brasília (UnB) podendo ser publicados posteriormente. Os dados e materiais utilizados na pesquisa ficarão sob a guarda do pesquisador por um período de no mínimo cinco anos, após isso serão destruídos ou mantidos na instituição.

Se o (a) Senhor (a) tiver qualquer dúvida em relação à pesquisa, por favor, entre em contato com o Prof. Dr. Gilberto Lacerda dos Santos, na Faculdade de Educação/ UnB, telefone (61) 3107-6243 ou pelo e-mail glacerda@unb.br.

Este documento foi elaborado em duas vias, uma ficará com o pesquisador responsável e a outra com o (a) colaborador (a) da pesquisa.

Por fim, declaro-me esclarecido (a) e dou o meu conhecimento para o uso das informações oferecidas para fins do estudo acadêmico mencionado.

(DF), de de 2015 . 


\section{Apropriação Didática do Tablet Educacional por Docentes do Ensino Médio da SEEDF}

Pesquisa acadêmica que visa conhecer o percurso de apropriação do tablet educacional pelos (as) docentes do Ensino Médio da SEEDF

*Obrigatório

\section{Termo de Consentimento e Livre Esclarecido - TCLE *}

Termo de Consentimento Livre e Esclarecido - TCLE O (a) Senhor (a) está sendo convidado (a) a participar da pesquisa intitulada Apropriação Didática do Tablet Educacional por Docentes do Ensino Médio da Secretaria de Estado de Educação do Distrito Federal, desenvolvida pelo pesquisador José Wrigell Menezes Rodrigues, no âmbito do Programa de Pós-Graduação em Educação, da Faculdade de Educação, da Universidade de Brasilia, como parte do Mestrado Acadêmico em Educação. O objetivo principal desta pesquisa é analisar como tem sido percurso de apropriação didática do tablet educacional, fornecido pelo Governo do Distrito Federal, pelos (as) docentes do Ensino Médio da Rede Pública de Ensino. Seus objetivos específicos são: conhecer os motivos que levaram o (a) docente a não aceitar/ aceitar, não ficar/ ficar e não usar/ usar o tablet educacional em sua rotina pedagógica; verificar se houve mudança na rotina pedagógica dos (das) docentes que usam o tablet educacional; e caracterizar o uso e o desuso pedagógico do tablet educacional, de acordo com a premissa do Programa Nacional de Tecnologia Educacional (Prolnfo). O (A) senhor (a) receberá todos os esclarecimentos necessários antes e no decorrer da pesquisa e lhe asseguramos que seu nome não aparecerá, sendo mantido o mais rigoroso sigilo através da omissão total de quaisquer informações que permitam identificá-lo (a). A sua participação será através de um questionário online. 0 procedimento tem um tempo estimado em 15 minutos para sua realização. Informamos que você pode se recusar a responder (ou participar) de qualquer procedimento, qualquer questão que lhe traga constrangimento, podendo desistir em qualquer momento, sem nenhum prejuízo para você. Sua participação é voluntária, isto é, não há pagamento por sua colaboração. Os resultados da pesquisa serão divulgados na Universidade de Brasília (UnB) podendo ser publicados posteriormente. Os dados e materiais utilizados na pesquisa ficarão sob a guarda do pesquisador por um período de no mínimo cinco anos, após isso serão destruídos ou mantidos na instituição. Se o (a) Senhor (a) tiver qualquer dúvida em relação à pesquisa, por favor, entre em contato com o Prof. Dr. Gilberto Lacerda dos Santos, na Faculdade de Educação/ UnB, telefone (61) 3107-6243 ou pelo e-mail glacerda@unb.br. Por fim, declaro-me esclarecido (a) e dou o meu conhecimento para o uso das informações oferecidas para fins do estudo acadêmico mencionado.

Estou ciente dos termos e CONCORDO em participar da pesquisa na qualidade de colaborador.

Estou ciente dos termos e NÃO CONCORDO em participar da pesquisa na qualidade de colaborador.

Continuar s

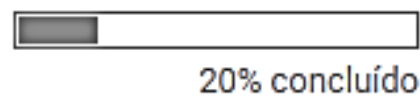




\section{APÊNDICE C}

\section{Questionário Geral}

1). Qual é a sua Coordenação Regional de Ensino? *

Marque a CRE de seu exercício
Brazlândia
Ceilândia
Gama
Guará
Núcleo Bandeirante
Paranoá
$\bigcirc$ Planaltina
Plano Piloto/ Cruzeiro
Recanto das Emas
Samambaia
Santa Maria
São Sebastião
Sobradinho
Taguatinga

\section{2). Licenciatura (s) em: *}

Marque a graduação cursada que habilita o exercício atual do magistério.
Pedagogia
História
$\bigcirc$ Química
LEM Inglês
Filosofia
Língua Portuguesa
Geografia
Biologia
LEM Espanhol
Matemática
Física
Educação Física
Sociologia
Arte
Outro: 


\section{APÊNDICE C}

3). Seu gênero é: *

Marque seu gênero.

Masculino

Feminino

4). Sua idade é: *

Marque a sua idade.

$\checkmark$

5). Seu tempo de exercício no magistério é de: *

Marque quantos anos você tem exercido o magistério. Registre seu tempo de experiência no magistério. $\checkmark$

6). Em seu curso de graduação/ licenciatura você cursou alguma disciplina que discutisse a didática voltada paras as tecnologias digitais? *

Marque "sim" se estudou, na graduação, didática para uso de tecnologias digitais. Marque "não" se não estudou, em seu curso de graduação, didática para uso das tecnologias digitais.

Sim

Não

7). Você participou de algum curso preparatório para uso de tecnologias digitais na escola? * Marque a opção adequada.

$\bigcirc \operatorname{Sim}$

Não

8). Você já operava algum dispositivo móvel com características similares a de um tablet? * Marque a resposta adequada.

$\bigcirc \mathrm{Sim}$

Não
"Voltar
Continuar n

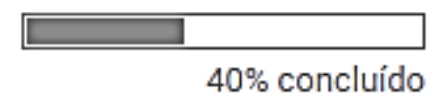




\section{APÊNDICE C}

\section{Questionário Nível 1}

Para todos (as) os (as) colaboradores de pesquisa.

1). Marque, de 1 a 4 , os aparelhos abaixo listados conforme sua frequência de uso fora da escola como meio de comunicação ou de informação. Coloque 0 para o (s) itens não utilizados. *

Marque 0 para dispositivos não utilizados. Marque de 1 a 4, conforme frequência de utilização.

\begin{tabular}{|c|c|c|c|c|c|}
\hline & 0 & 1 & 2 & 3 & 4 \\
\hline $\begin{array}{l}\text { Personal } \\
\text { Computer (PC) }\end{array}$ & 0 & 0 & 0 & 0 & 0 \\
\hline Tablet & $\mathrm{O}$ & $\mathrm{O}$ & $\mathrm{O}$ & $\mathrm{O}$ & $\mathrm{O}$ \\
\hline Smartphone & 0 & $\mathrm{O}$ & 0 & 0 & 0 \\
\hline $\begin{array}{l}\text { Notebook/ } \\
\text { Laptops }\end{array}$ & $\mathrm{O}$ & $\mathrm{O}$ & $\mathrm{O}$ & $\mathrm{O}$ & O \\
\hline
\end{tabular}

2). Você aceitou receber o tablet educacional? *

Marque a opção adequada.

Sim.

Não.

3). Que motivos te levaram a aceitar ou não aceitar o tablet educacional? * Descreva os motivos que o incentivaram a aceitar ou não o tablet educacional.

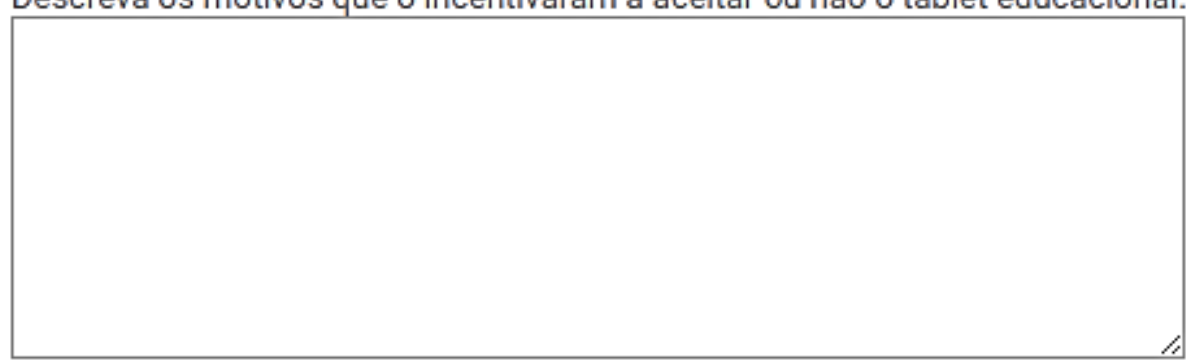

4). Caso tenha aceitado o tablet educacional, clique em SIM. Caso não tenha aceitado, clique em NÃo.

Clicando em SIM a pesquisa continuará. Clicando em Não a pesquisa será encerrada e o formulário enviado.

$\bigcirc \mathrm{Sim}$

Não

"Voltar

Continuar

$60 \%$ concluído 


\section{APÊNDICE C}

\section{Questionário Nível 2}

Para os (as) docentes que receberam o tablet educacional.

1). Você ficou com o tablet educacional por um período igual ou superior a 10 dias? *

Marque a opção adequada.

$\bigcirc \operatorname{sim}$

Não

2). Quais foram suas impressões sobre ele? *

Descreva o que pode perceber ao operá-lo.

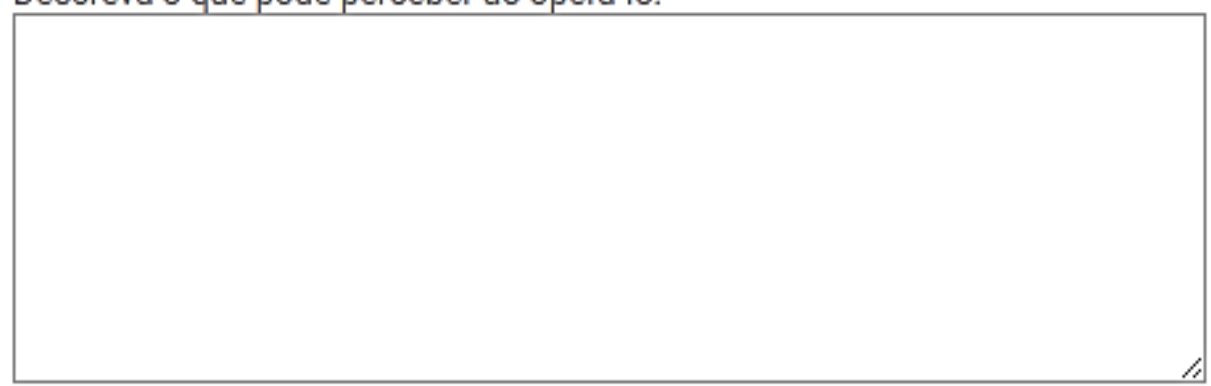

3). Caso tenha ficado com o tablet educacional por um período igual ou superior a 10 dias, marque SIM. Caso tenha devolvido o tablet educacional em período inferior a 10 dias, marque NÂO.

Ao marcar SIM a pesquisa continuará. Ao marcar Não a colaboração será encerrada e o formulário enviado.

$\bigcirc \mathrm{Sim}$

Não

« Voltar
Continuar

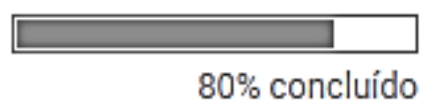

Powered by

目 Google Forms
Este conteúdo não foi criado nem aprovado pelo Google.

Denunciar abuso - Termos de Serviço - Termos Adicionais 


\section{APÊNDICE C}

\section{Questionário Nível 3}

Para os (as) docentes que permaneceram em posse do tablet educacional.

1). Você participou do curso "Tablet Educacional como ferramenta pedagógica"? * Marque a opção adequada.

$\bigcirc \mathrm{Sim}$

Não

2). Você concluiu e foi certificado? *

Marque a opção adequada.

$\bigcirc$ Sim, concluí e recebi o certificado

Não concluí o curso.

$\bigcirc$ Não se aplica.

3). Você já havia participado de outros programas de inclusão digital de docentes (PROUCA, Professor Informatizado - subsídio de notebooks ou outros)? *

Marque a opção adequada.

$\bigcirc \operatorname{Sim}$

Não

4). Quais são (foram) as atividades mais comuns de uso do tablet educacional? * Marque de 1 a 10, conforme frequência de uso. Marque 0 para as atividades não realizadas.

\begin{tabular}{|c|c|c|c|c|c|c|c|c|c|c|c|c|}
\hline & 0 & 1 & 2 & 3 & 4 & 5 & 6 & 7 & 8 & 9 & 10 & \\
\hline $\begin{array}{l}\text { Interação em } \\
\text { redes sociais }\end{array}$ & 0 & 0 & $\mathrm{O}$ & O & 0 & O & O & $\mathrm{O}$ & 0 & 0 & 0 & $\mathrm{O}$ \\
\hline $\begin{array}{l}\text { Busca de } \\
\text { informação }\end{array}$ & 0 & 0 & 0 & 0 & 0 & $\mathrm{O}$ & 0 & 0 & 0 & 0 & 0 & 0 \\
\hline Jogos & 0 & 0 & $\mathrm{O}$ & $\mathrm{O}$ & 0 & 0 & 0 & $\mathrm{O}$ & 0 & 0 & 0 & 0 \\
\hline Música & $\mathrm{O}$ & 0 & $\mathrm{O}$ & $\mathrm{O}$ & 0 & $\mathrm{O}$ & O & $\mathrm{O}$ & 0 & $\mathrm{O}$ & 0 & 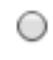 \\
\hline $\begin{array}{l}\text { Correio eletrônico } \\
\text { (e-mail) }\end{array}$ & 0 & 0 & $\mathrm{O}$ & 0 & 0 & $\mathrm{O}$ & 0 & 0 & 0 & 0 & 0 & 0 \\
\hline Leitura variada & $\mathrm{O}$ & 0 & $\mathrm{O}$ & 0 & 0 & $\mathrm{O}$ & 0 & $\mathrm{O}$ & 0 & $\mathrm{O}$ & 0 & 0 \\
\hline Vídeos & 0 & 0 & 0 & 0 & 0 & 0 & 0 & 0 & 0 & 0 & 0 & 0 \\
\hline Fotografias & 0 & 0 & $\mathrm{O}$ & 0 & 0 & $\mathrm{O}$ & 0 & 0 & 0 & 0 & 0 & 0 \\
\hline $\begin{array}{l}\text { Preenchimento de } \\
\text { diário }\end{array}$ & 0 & 0 & 0 & 0 & 0 & 0 & 0 & 0 & 0 & 0 & 0 & 0 \\
\hline Outros & 0 & 0 & 0 & 0 & 0 & 0 & 0 & 0 & 0 & 0 & 0 & 0 \\
\hline
\end{tabular}




\section{APÊNDICE C}

5). Você considera o tablet educacional uma ferramenta pedagógica (que possa ser utilizada para ampliar as possibilidades de ensino e de aprendizagem)? *

Marque a opção adequada.

Sim

○ão

6). Você utiliza (utilizava) o tablet educacional em sua rotina pedagógica? *

Marque a opção adequada.

Sim

Não

7). Qual é (foi) a utilização mais comum do tablet educacional na rotina pedagógica? * Marque a opção adequada.

Não vejo utilização do tablet em minha rotina pedagógica.

Divulgação de eventos.

Aprofundamento de conteúdo.

Fórum de discussão.

Revisão de conteúdos.

Jogos com objetivo pedagógico

Outros.

8). Você percebe (percebeu) alguma melhoria em seu exercício após a adoção do tablet educacional? *

Marque a opção adequada.

Sim

Não

9). A melhoria percebida é (foi) no (a): * Marque a (s) opção (opções) adequada (s).

Não percebo melhoria alguma.

Rendimentos dos estudantes

Relação com o conhecimento

Planejamento do trabalho

Relação entre os docentes

Relação com os estudantes

Ensino em sala de aula

Comunicação institucional

Uso das tecnologias digitais

Outros. 


\section{APÊNDICE C}

10). Quais são (foram) as dificuldades mais comuns na utilização do tablet educacional na escola? *

Marque a (as) opção (opções) adequadas.

Falta de internet

Problemas no tablet (hardware)

Problemas nos aplicativos

$\checkmark$ Falta de tempo para conhecer a ferramenta

$\square$ Pouco conhecimento da ferramenta

Pouco ou nenhum incentivo para o uso

Poucos aplicativos para uso na disciplina

Outros

11). 0 ambiente escolar foi favorável ao uso de Tecnologias Digitais, em especial o tablet educacional? *

Marque a opção adequada.

Sim

Não.

12). Caso queira participar da próxima etapa da pesquisa (entrevista), deixe seu e-mail que entraremos em contato.

Escreva seu e-mail caso queira participar da etapa das entrevista. Em breve entraremos em contato.

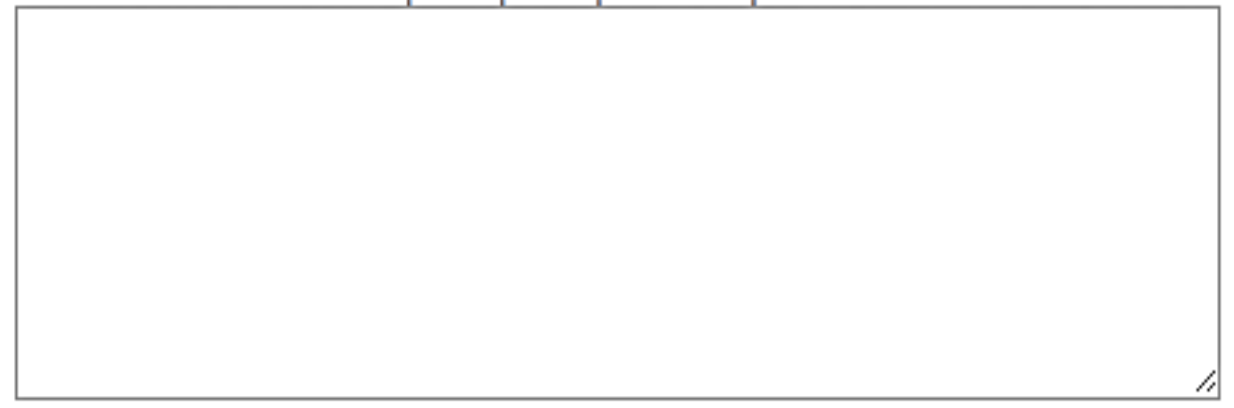

"Voltar

\section{Enviar}

Nunca envie senhas pelo Formulários Google. 


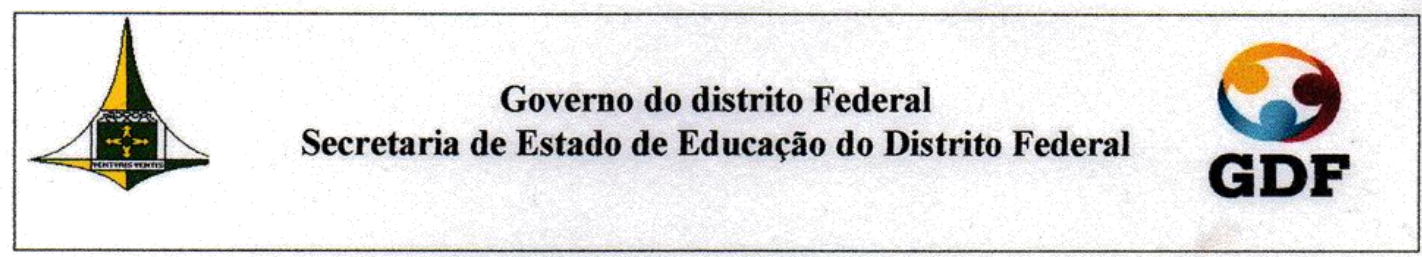

\section{TERMO DE PERMISSÃO DE USO E GUARDA}

$\mathrm{O}(\mathrm{A}) \quad$ professor(a)
matrícula $\longrightarrow$ atualmente lotado como docente do ensino médio na unidade escolar da Coordenação Regional de Ensino de recebeu da Secretaria de Estado de Educação do Distrito Federal um tablet educacional de 7" para uso profissional de pesquisa e formação continuada para o uso de tecnologias da informação em projetos pedagógicos.

$\mathrm{O}$ (a) professor(a) toma ciência de que o equipamento encontra-se patrimoniado sob o $\mathrm{n}^{\circ}$ à Secretaria de Estado de Educação do Distrito Federal, doravante nominada permitente, e representada neste ato pelo Coordenador de Patrimônio mat.

Tal equipamento permanecerá sob a guarda do (a) professor(a) enquanto este(a) estiver atuando como docente do ensino médio. Portanto, em caso de afastamento permitido, seja disposição funcional, afastamentos, licença especial, licença sem vencimento, exoneração, aposentadoria, licença médica superior a 30 dias, desligamento ou rescisão contratual da rede pública de ensino, ausência, desistência ou reprovação no curso de formação, o(a) professor(a) deverá devolver o equipamento ao representante da permitente.

$\mathrm{O}(\mathrm{A})$ professor(a) compromete-se a participar do curso de formação para o uso pedagógico do tablet e oficinas de formação continuada para o uso da tecnologia, promovidos pela SEDF e/ou CRE, a cuja Unidade Escolar estiver vinculada, estando ciente da sanção a ser aplicada em caso da não observância das condições expressas no parágrafo acima.

Brasília, de de 2013.

\section{Professor}

do curso de formação para o uso pedagógico do tablet/ 


\section{RELATÓRIO FINAL DE CURSO}

\begin{tabular}{|l|l|}
\hline \multicolumn{2}{|c|}{ Curso: Novas Tecnologias Educacionais como Ferramenta Pedagógica } \\
\hline Articulador Pedagógico: Tadeu Maia \\
\hline № de Turmas: 39 & № de Inscritos: 1372 \\
\hline № de cursistas concluintes: 98 & \\
\hline
\end{tabular}

O curso Novas Tecnologias Educacionais como Ferramenta Pedagógica elaborado pela equipe pedagógica da Gerência de Educação a Distância da Escola de Aperfeiçoamento dos Profissionais da Educação da Secretaria de Estado de Educação do DF foi uma formação envolvendo de forma compulsória todos os professores regentes de ensino médio que receberam o dispositivo móvel Tablet Educacional, distribuído pela Subsecretaria de Modernização e Tecnologia desta SEEDF. Para a realização da proposta, a SEEDF contou com a pareceria da Escola de Governo no que se refere à seleção, contratação e, consequentemente, a remuneração de tutores para atuarem nas horas online do curso em questão.

O objetivo desta formação foi a familiarização dos professores envolvidos com as tecnologias da educação e informação, especialmente, o uso do tablet como recurso pedagógico. Assim, os temas apresentados aliavam o aprofundamento teórico com atividades práticas que 0 docente poderia imediamente inseri-las em sua prática docente, uma vez que estes já estavam de posse do dispositivo supracitado.

A parte a distância da formação foi desenvolvida no Ambiente Virtual de Aprendizagem (AVA) - Moodle/EAPE. O material de estudo foi fornecido pela Escola de Governo e mediado pelos tutores contratados por essa escola. A plataforma não apresentou problemas técnicos de qualquer ordem. Outrossim, todas as atividades e conteúdos forma disponibilizados dentro do cronograma previsto. Os tutores realizaram o acompanhamento dos cursistas conforme orientaçōes fornecidas por esta coordenação, sem quaisquer dificuldades que atrapalhasse a realização do curso pelos inscritos.

Entretanto, o curso não teve adesão destes docentes, culminando em baixa frequência. Dentre as possíveis causas, estão:

- A compulsoriedade;

- O período de realização do curso, já que este aconteceu no último semestre;

- Excesso de formaçōes ofertadas aos docentes.

Brasilia, 27 de março de 2014.

Tadeu Queiroz Maia

(articulador do curso) 